\title{
Factors controlling variability in the oxidative capacity of the troposphere since the Last Glacial Maximum
}

\author{
L. T. Murray ${ }^{1, *}$, L. J. Mickley ${ }^{1}$, J. O. Kaplan ${ }^{2}$, E. D. Sofen ${ }^{3}$, M. Pfeiffer ${ }^{2}$, and B. Alexander ${ }^{3}$ \\ ${ }^{1}$ School of Engineering and Applied Sciences, Harvard University, Cambridge, MA, USA \\ ${ }^{2}$ ARVE Group, École Polytechnique Fédérale de Lausanne, Lausanne, Switzerland \\ ${ }^{3}$ Department of Atmospheric Sciences, University of Washington, Seattle, WA, USA \\ *now at: Lamont-Doherty Earth Observatory, Columbia University, Palisades, NY, USA
}

Correspondence to: L. T. Murray (ltmurray@post.harvard.edu)

Received: 2 July 2013 - Published in Atmos. Chem. Phys. Discuss.: 17 September 2013

Revised: 11 February 2014 - Accepted: 14 February 2014 - Published: 9 April 2014

\begin{abstract}
The oxidative capacity of past atmospheres is highly uncertain. We present here a new climate-biospherechemistry modeling framework to determine oxidant levels in the present and past troposphere. We use the GEOS-Chem chemical transport model driven by meteorological fields from the NASA Goddard Institute of Space Studies (GISS) ModelE, with land cover and fire emissions from dynamic global vegetation models. We present time-slice simulations for the present day, late preindustrial era (AD 1770), and the Last Glacial Maximum (LGM, 19-23 ka), and we test the sensitivity of model results to uncertainty in lightning and fire emissions. We find that most preindustrial and paleo climate simulations yield reduced oxidant levels relative to the present day. Contrary to prior studies, tropospheric mean $\mathrm{OH}$ in our ensemble shows little change at the LGM relative to the preindustrial era $(0.5 \pm 12 \%)$, despite large reductions in methane concentrations. We find a simple linear relationship between tropospheric mean ozone photolysis rates, water vapor, and total emissions of $\mathrm{NO}_{\mathrm{x}}$ and reactive carbon that explains $72 \%$ of the variability in global mean $\mathrm{OH}$ in 11 different simulations across the last glacial-interglacial time interval and the industrial era. Key parameters controlling the tropospheric oxidative capacity over glacial-interglacial periods include overhead stratospheric ozone, tropospheric water vapor, and lightning $\mathrm{NO}_{\mathrm{x}}$ emissions. Variability in global mean $\mathrm{OH}$ since the LGM is insensitive to fire emissions. Our simulations are broadly consistent with ice-core records of $\Delta^{17} \mathrm{O}$ in sulfate and nitrate at the LGM, and $\mathrm{CO}, \mathrm{HCHO}$, and $\mathrm{H}_{2} \mathrm{O}_{2}$ in the preindustrial era. Our results imply that the glacial-interglacial changes in atmospheric methane ob-
\end{abstract}

served in ice cores are predominantly driven by changes in its sources as opposed to its sink with $\mathrm{OH}$.

\section{Introduction}

The oxidative capacity of the troposphere - primarily characterized by the burden of the four most abundant and reactive oxidants $\left(\mathrm{OH}\right.$, ozone, $\mathrm{H}_{2} \mathrm{O}_{2}$, and $\left.\mathrm{NO}_{3}\right)$ - determines the lifetime before removal of many trace gases of importance to climate and human health, including air pollutants and the greenhouse gas methane (Fiore et al., 2012). Ozone itself absorbs both longwave and shortwave radiation, and its tropospheric enhancement since the Industrial Revolution is estimated to have contributed the third largest radiative forcing effect of any gas over this period, after $\mathrm{CO}_{2}$ and methane (IPCC, 2007). Oxidants also impact the evolution, lifetime, and physical properties of inorganic and primary and secondary organic aerosol particles, modulating their direct and indirect radiative effects (Liao et al., 2003; Tie et al., 2005; Leibensperger et al., 2011). The tropospheric oxidative capacity may perturb terrestrial and marine ecosystems via oxidative stress and by altering deposition patterns of oxidized nutrients such as nitrate (Shepon et al., 2007; Sitch et al., 2007; Collins et al., 2010). Understanding how tropospheric oxidative capacity has changed over the past is critical for understanding its chemical, climatic, and ecological consequences. The oxidation capacity of past atmospheres, however, is uncertain. In this work, we introduce a new offline-coupled model framework to improve estimates 
of the oxidative capacity on glacial-interglacial timescales, and we examine the implications of our results for current understanding of the observed ice-core record of methane.

Tropospheric oxidant levels respond in well known but complex ways to meteorological conditions, changes in emissions of key chemical species, and changes in surface and stratospheric boundary conditions. These parameters include temperature, clouds, water vapor concentrations, overhead ozone columns, aerosols, and emissions of reactive oxides of nitrogen $\left(\mathrm{NO}_{\mathrm{x}}\right)$, carbon monoxide, and volatile organic compounds (VOCs) such as methane (e.g., Thompson and Stewart, 1991; Spivakovsky et al., 2000; Lelieveld et al., 2002; Holmes et al., 2013). This sensitivity suggests that multi-millennial global environmental change, including changes in climate and land cover, should affect tropospheric oxidative capacity.

Direct measurement of atmospheric oxidants is difficult at present, and nearly impossible for the past because most oxidants are highly reactive. The limited historical observations of oxidant abundance that do exist imply that human activity has indeed substantially perturbed the tropospheric oxidants since the preindustrial era (hereafter referred to as the preindustrial) (e.g., Staffelbach et al., 1991; Marenco et al., 1994; Anklin and Bales, 1997). The Last Glacial Maximum (LGM, 19-23 ka) is well characterized by ice-core and sediment records, but no oxidants except for $\mathrm{H}_{2} \mathrm{O}_{2}$ are preserved in ice cores, and the $\mathrm{H}_{2} \mathrm{O}_{2}$ record is complicated by postdepositional processes (Hutterli et al., 2003). Proxies for oxidant levels have been proposed, such as those from HCHO and methane (Staffelbach et al., 1991) or oxygen isotope anomalies in sulfate and nitrate (e.g., Alexander et al., 2002, 2004; Kunasek et al., 2008), but these require models for interpretation in a global context. For methane, for example, there remains considerable uncertainty regarding the relative contributions of the wetland emissions source vs. the $\mathrm{OH}$ sink in driving the large glacial-interglacial variability seen in ice-core bubbles (Khalil and Rasmussen, 1987; Chappellaz et al., 1993; Crutzen and Brühl, 1993; Chappellaz et al., 1997; Martinerie et al., 1995; Brook et al., 2000; Kaplan, 2002; Kaplan et al., 2006; Valdes et al., 2005; Levine et al., 2011c; Weber et al., 2010; Fischer et al., 2008; Singarayer et al., 2011; Levine et al., 2012).

Prior modeling studies that investigated past changes in the tropospheric oxidants have disagreed on the magnitude and even the sign of changes, as summarized in Table 1. These discrepancies reflect differences in the model components of the Earth system allowed to vary, the differing degrees of complexity in the representation of those components, and the large uncertainties in past meteorological and biological conditions. Contributing to the uncertainty in estimates of past oxidative capacity is the fact that the principal oxidants are strongly and nonlinearly coupled to one another (Thompson, 1992). Models agree on the sign of the change in the global tropospheric mean ozone since the preindustrial, with estimates of the change ranging from 25 to $65 \%$
(Wang and Jacob, 1998; Lelieveld and Dentener, 2000; Shindell, 2001; Young et al., 2013), but they have been unable to reproduce low surface concentrations of ozone implied by late-19th-century observations (Marenco et al., 1994; Pavelin et al., 1999; Mickley et al., 2001). How OH changed over this period is even more uncertain, with recent simulations from 16 state-of-the-science models of the Atmospheric Chemistry and Climate Model Intercomparison Project (ACCMIP) finding a mean change of $-0.6 \pm 8.8 \%$ from 1850 to 2000 , even with identical anthropogenic emission inventories applied (Naik et al., 2013).

At the LGM, previous studies have generally found 20$30 \%$ decreases in surface or free tropospheric ozone relative to the preindustrial (Valdes et al., 2005; Kaplan et al., 2006; Karol et al., 1995). Most prior model studies have concluded that $\mathrm{OH}$ concentrations at the LGM were about $25 \%$ higher than the preindustrial (range of $10-56 \%$ ) because of lower hydrocarbon and CO concentrations (Law and Pyle, 1991; Crutzen and Zimmermann, 1991; Pinto and Khalil, 1991; Lu and Khalil, 1991; Martinerie et al., 1995; Valdes et al., 2005; Kaplan et al., 2006; Thompson et al., 1993, , and references therein), although the 1-D simulations by Karol et al. (1995) on average found $25 \%$ less OH at the surface. However, no LGM model study to date has considered the full suite of changes in the key variables for controlling tropospheric oxidants in a 3-D framework, in particular the effect of the stratospheric ozone burden on photolysis rates in the troposphere, to which $\mathrm{OH}$ is especially sensitive (e.g., Holmes et al., 2013).

This study introduces the ICE age Chemistry And Proxies (ICECAP) project, which adopts as its central component a stepwise, offline-coupled framework for simulating the chemical composition of the atmosphere at and since the LGM. Our primary goal is to test, in a 3-D model, the sensitivity of tropospheric oxidants across the range of uncertainty in their controlling factors, with as much internal consistency as possible. Offline coupling, as opposed to using an integrated Earth system model, allows for rapid sensitivity tests and facilitates identification of first-order effects. To that end, we use a general circulation model (GCM) to simulate meteorology for four different time slices: the present day (ca. 1990s), the late preindustrial (ca. 1770s), and two different possible representations of the LGM (19-23 ka), one significantly colder than the other to span the range of likely LGM conditions. Second, we use the simulated meteorology to determine land cover with an equilibrium terrestrial biosphere model. We then apply the archived meteorology and land cover products to a detailed chemical transport model (CTM), using an online-coupled linearized stratospheric chemistry scheme for upper-boundary conditions. We allow tropospheric emissions of trace gases and aerosols to respond to climate within the CTM, and test the sensitivity of our results to two large sources of uncertainty: lightning and fires. 
Table 1. Percentage changes in tropospheric burdens of $\mathrm{OH}$, ozone and $\mathrm{H}_{2} \mathrm{O}_{2}$, relative to the preindustrial, compiled from the literature

\begin{tabular}{|c|c|c|c|c|c|c|}
\hline \multirow[b]{2}{*}{ Reference } & \multicolumn{2}{|c|}{$\% \Delta$ at LGM } & \multicolumn{3}{|c|}{$\% \Delta$ at present day } & \multirow[b]{2}{*}{ Method } \\
\hline & $\mathrm{OH}$ & Ozone & $\mathrm{OH}$ & Ozone & $\mathrm{H}_{2} \mathrm{O}_{2}$ & \\
\hline McElroy (1989) & $+56 \%$ & - & $+60 \%$ & - & - & 1-D model \\
\hline Hough and Derwent (1990) & - & - & $-19 \%$ & - & - & 2-D model \\
\hline Valentin (1990) & $+23 \%$ & $0 \%$ & $-9 \%$ & $+64 \%$ & - & 2-D model \\
\hline Law and Pyle (1991) & - & - & $-13 \%$ & $+300 \%$ & - & 2-D model \\
\hline Pinto and Khalil (1991), Lu and Khalil (1991) & $+15 \%,+26 \%$ & $-17 \%$ & $-4 \%$ & $+57 \%$ & - & 1-D model, multi 1-D model \\
\hline Staffelbach et al. (1991) & - & - & $-23 \%$ & - & - & Ice-core $\mathrm{HCHO}$ \\
\hline Crutzen and Zimmermann (1991) & - & - & $-10 \%$ to $-20 \%$ & $+50 \%$ & - & 3-D model \\
\hline Thompson et al. (1993) & $+10 \%$ & $-20 \%$ & $-17 \%$ & $+80 \%$ & - & Multi 1-D model \\
\hline Martinerie et al. (1995) & $+20 \%$ & $-30 \%$ to $+30 \%{ }^{\mathrm{a}}$ & $+6 \%$ & $\mathrm{Up}$ to $+250 \%{ }^{\mathrm{a}}$ & - & 2-D model \\
\hline Karol et al. (1995) & $-60 \%$ to $+14 \%$ b & $-29 \%$ to $+12 \% \mathrm{~b}$ & $+9 \%$ to $+12 \% \mathrm{~b}$ & $+56 \%$ to $+73 \% \mathrm{~b}$ & - & Multi 1-D model \\
\hline Levy et al. (1997) & - & - & - & $+39 \%$ & - & 3-D model \\
\hline Berntsen et al. (1997) & - & - & $+6.80 \%$ & $+53 \%$ & $+100 \%$ & 3-D model \\
\hline Roelofs et al. (1997) & - & - & $-22 \%$ & $+43 \%$ & - & 3-D model \\
\hline Brasseur et al. (1998) & - & - & $-17 \%$ & $+20 \%$ to $+80 \% \mathrm{a}$ & - & 3-D model \\
\hline Wang and Jacob (1998) & - & - & $-9.60 \%$ & $+63 \%$ & - & 3-D model \\
\hline Mickley et al. (1999) & - & - & $-16 \%$ & $+56 \%$ & - & 3-D model \\
\hline Lelieveld and Dentener (2000) & - & - & - & $+25 \%$ & - & 3-D model \\
\hline Grenfell et al. (2001) & - & - & $-3.90 \%$ & $+38 \%$ & - & 3-D model, no NMVOCs \\
\hline Hauglustaine and Brasseur (2001) & - & - & $-31 \%$ & $+57 \%$ & - & 3-D model \\
\hline Shindell et al. (2001) & - & - & $-5.90 \%$ & $+45 \%$ & - & 3-D model \\
\hline Lelieveld et al. (2002) & - & - & $-5 \%$ & $+30 \%$ & - & 3-D model \\
\hline Lamarque et al. (2005) & - & - & $-8 \%$ & $+30 \%$ & - & 3-D model \\
\hline Valdes et al. (2005) & $+25 \% \mathrm{~b}$ & $-17 \% \mathrm{~b}^{\mathrm{b}}$ & - & - & - & 3-D model \\
\hline Kaplan et al. (2006) & $+28 \%$ & $-31 \%$ & - & - & - & 3-D model \\
\hline Shindell et al. (2006) & - & - & $-16 \%$ & $+11 \%$ & - & 3-D model \\
\hline Sofen et al. (2011) & - & - & $-10 \%$ & $+42 \%$ & $+58 \%$ & 3-D model \\
\hline Parrella et al. (2012) & - & - & - & $+47 \%$ to $+48 \%$ & - & 3-D model \\
\hline Bock et al. (2012) & $+14 \%$ & - & - & - & - & 2-D model \\
\hline Naik et al. (2013), Young et al. (2013) & - & - & $-0.6 \pm 8.8 \%$ & $+41 \pm 8.9 \%$ & - & Multi 3-D model \\
\hline This work, ensemble estimate ${ }^{c}$ & $+0.5 \pm 12 \%$ & $-20 \pm 9 \%$ & $+7.0 \pm 4.3 \%$ & $+28 \pm 11 \%$ & $+18 \pm 22 \%$ & Multi 3-D model \\
\hline This work, best estimate ${ }^{\mathrm{c}}$ & $+1.7 \%$ & $-20 \%$ & $+5.30 \%$ & $+35 \%$ & $+31 \%$ & 3-D model \\
\hline
\end{tabular}

${ }^{\mathrm{b}}$ Difference reported for mean surface concentration ${ }^{\mathrm{c}} \mathrm{cf}$. Sect. 5 for description of ensemble and best estimates.

This paper focuses on the tropospheric gas-phase chemistry component of the ICECAP project. In a separate paper, we will evaluate and interpret the role of aerosol particles on composition and climate across glacial-interglacial periods.

Section 2 describes the climate, chemistry, and land models used, and the manner in which they have been coupled to one another. Section 3 summarizes and evaluates the four different climate simulations, focusing on the changes that are most significant for tropospheric chemistry. Section 4 describes the response of natural emissions to changing climate as well as the scenarios we employ to test the sensitivity to uncertainties in past lightning and fire emissions. Section 5 presents the resulting changes in tropospheric oxidants and identifies their controlling factors, with particular focus on $\mathrm{OH}$. Section 6 evaluates and discusses the model results in the context of the ice-core record. Section 7 discusses the implications of our results for the methane record. We conclude with a summary section.

\section{Methods: project and model description}

Figure 1 illustrates the stepwise offline coupling of the ICECAP project framework. Archived meteorology for multiple time slices from the NASA Goddard Institute of Space Studies (GISS) ModelE GCM (Schmidt et al., 2006) are applied to the global vegetation models BIOME4-TG (Kaplan et al., 2006) to determine land cover characteristics and LPJ-LMfire (Pfeiffer et al., 2013) to calculate dry matter consumed by fires. The archived meteorology and land cover products are then used to drive the GEOS-Chem CTM of tropospheric composition (Bey et al., 2001), which includes online linearized stratospheric chemistry (McLinden et al., 2000).

\subsection{The GISS ModelE general circulation model}

The ModelE version of the GISS GCM of global climate is described in detail by Schmidt et al. (2006). The GISS GCM has a long history in investigations of past atmospheres (e.g., Webb et al., 1997; Joussaume et al., 1999; Delaygue et al., 2000; Shindell et al., 2003; Schmidt and Shindell, 2003; LeGrande et al., 2006; Rind et al., 2001, 2009). We use here ModelE with $4^{\circ}$ latitude $\times 5^{\circ}$ longitude horizontal resolution and 23 vertical layers extending from the surface to $0.002 \mathrm{hPa}$. We archive mean meteorological fields from ModelE for input to GEOS-Chem at temporal resolution of $6 \mathrm{~h}$ for three-dimensional fields (e.g., winds, convective mass fluxes) and $3 \mathrm{~h}$ for mixing depths and surface fields (e.g., surface temperature, solar radiation, albedo). The horizontal resolution used here is relatively coarse but still common for simulations of global chemistry models 


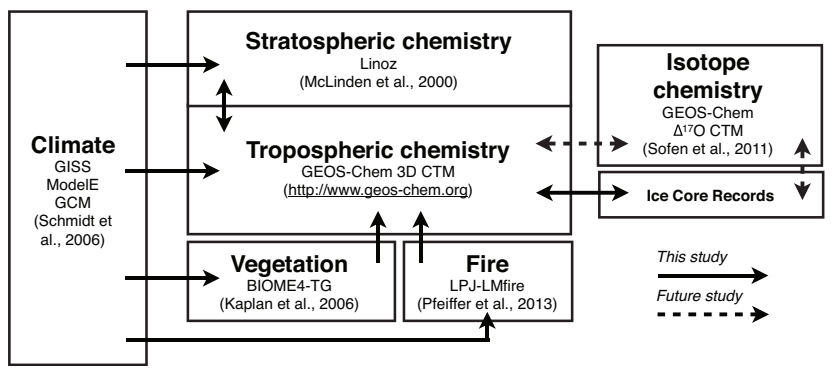

Fig. 1. The ICE age Chemistry And Proxies (ICECAP) framework. Each box represents a separate model or measurement, except for stratospheric and tropospheric chemistry, which are online together in GEOS-Chem. Arrows indicate the coupling between models and measurements as used in this study. Dashed arrows indicate future work.

(e.g., Lamarque et al., 2013). Climate in ModelE is forced by different greenhouse gas levels from ice-core measurements, orbital parameters, topography, and fixed sea ice and sea surface temperatures (SSTs) as summarized in Table 2 and discussed in Sect. 3. For each scenario the GCM is initialized for five years, with four subsequent years of meteorology then archived for the terrestrial vegetation and chemical transport models. We discuss the forcings applied to the GISS climate model for each of the scenarios and the resulting climate in Sect. 3.1.

\subsection{The BIOME4-TG global vegetation model}

BIOME4-TG (Kaplan et al., 2006) is an equilibrium terrestrial vegetation model that calculates the global distribution of 28 biomes and a suite of associated biogeochemical state variables and fluxes. The model is driven by climatological mean monthly climate, soil texture in two layers, and atmospheric $\mathrm{CO}_{2}$ concentrations. BIOME4-TG has been used extensively for simulating past vegetation distributions and for evaluating paleoclimate simulations from GCMs against paleoecological archives (e.g., Kaplan, 2002; Kaplan et al., 2003, 2006; Harrison and Prentice, 2003). For this study, we drive BIOME4-TG with a standard baseline climatology (Kaplan et al., 2006) to which we add monthly mean anomalies of surface temperature, precipitation, and solar radiation from the GISS ModelE paleo and preindustrial climate scenarios. The BIOME4-TG outputs passed to GEOS-Chem are biome classification and each biome's constituent plant functional types (PFTs), as well as aggregate leaf area index (LAI). The PFTs and LAI are used for determining terrestrial plant emissions of VOCs (Sect. 4.2); LAI and biome classes are used in calculating dry deposition velocities in a resistance-in-series model in GEOS-Chem (Wesely, 1989). We elect to represent present-day land cover with BIOME4-TG rather than prescribe it from satellite products (as normal for GEOS-Chem) for consistency between simulations. However, to represent anthropogenic land use, we su- perimpose a present-day crop fraction mask from the Model of Emissions of Gases and Aerosols from Nature (MEGAN) version 2.1 (Guenther et al., 2012).

\subsection{The LPJ-LMfire global biomass burning model}

LPJ-LMfire (Pfeiffer et al., 2013) is a dynamic global vegetation model designed to simulate biomass burning from natural and human-caused wildfires in preindustrial time. The model further accounts for intentional burning of agricultural land and pastures in preindustrial societies. Similarly to BIOME4-TG, we drive LPJ-LMfire with a standard baseline climatology (Pfeiffer et al., 2013) to which we add monthly mean anomalies of mean temperature, diurnal temperature range, precipitation, total cloud cover fraction, surface and wind speed from the GISS ModelE scenarios. Monthly anomalies of lightning ground-strike rate determined by GEOS-Chem (Sect. 4.5) are also used to drive LPJ-LMfire in the paleoclimate experiments. We archive monthly total dry mass of biomass burned for use in GEOS-Chem.

\subsection{The GEOS-Chem chemical transport model}

The GEOS-Chem global CTM (version 9-01-03, with modifications as described; http://www.geos-chem.org) simulates tropospheric ozone- $\mathrm{NO}_{\mathrm{x}}-\mathrm{CO}-\mathrm{VOC}-\mathrm{BrO}_{\mathrm{x}}$-aerosol chemistry. Emissions and their coupling with the GCM and vegetation model outputs are the subject of Sect. 4. The original description of the chemical mechanism is by Bey et al. (2001). The coupled sulfur-nitrate-ammonium aerosol simulation is described by Park et al. (2004), with aerosol thermodynamics computed via the ISORROPIA II model (Fountoukis and Nenes, 2007) as implemented by Pye et al. (2009). Sea salt aerosol is described by Jaeglé et al. (2011), primary and secondary organic aerosol by Heald et al. (2011), and black carbon by Wang et al. (2011). Recent updates of relevance for this study include those to oceanic sources and sinks of acetone (Fischer et al., 2012), optical properties of dust (Ridley et al., 2012), and snow scavenging and washout of aerosols (Wang et al., 2011). We include online bromine chemistry (Parrella et al., 2012), whose catalytic destruction of ozone may be an important mechanism for limiting preindustrial ozone levels.

In their study of effect of climate change on surface air quality in the near future, $\mathrm{Wu}$ et al. (2007) coupled GEOS-Chem with the GISS III version of the GISS GCM (Rind et al., 2007). Here, we build upon the Wu et al. (2007) framework, using meteorology from GISS ModelE to drive GEOS-Chem chemistry. Primary differences between the Wu et al. (2007) implementation and this work include the prescription of land cover from an offline global terrestrial vegetation model (Sects. 2.2-2.3 and 4.2), a linearized stratospheric ozone scheme, adjusted convective transport and rainout schemes to reflect the updated moist convection in ModelE (Kim et al., 2012), and implementation of the GISS 
Table 2. Climate forcings used in GISS ModelE for each climate scenario.

\begin{tabular}{|c|c|c|c|c|}
\hline \multirow{2}{*}{ Simulation parameters } & \multicolumn{2}{|c|}{ Last Glacial Maximum (21 ka) } & \multirow{2}{*}{$\begin{array}{c}\text { Preindustrial } \\
\text { (ca. 1770s) }\end{array}$} & \multirow{2}{*}{$\begin{array}{l}\text { Present day } \\
\text { (ca. 1990s) }\end{array}$} \\
\hline & Cold LGM & Warm LGM & & \\
\hline \multicolumn{5}{|l|}{ Greenhouse gases (ppmv) } \\
\hline $\mathrm{CO}_{2}$ & 188 & 188 & 280 & 354 \\
\hline $\mathrm{N}_{2} \mathrm{O}$ & 0.20 & 0.20 & 0.27 & 0.31 \\
\hline $\mathrm{CH}_{4}$ & 0.39 & 0.39 & 0.73 & 1.69 \\
\hline CFCs & 0 & 0 & 0 & 1990 values \\
\hline SST and sea ice & Webb et al. (1997) & CLIMAP (1976) & $\begin{array}{c}1880 \mathrm{~s} \\
\text { Rayner et al. (2003) }\end{array}$ & $\begin{array}{l}1990 \mathrm{~s} \\
\text { Rayner et al. (2003) }\end{array}$ \\
\hline Ice sheet topography & Licciardi et al. (1998) & Licciardi et al. (1998) & Present day & Present day \\
\hline Stratospheric ozone ${ }^{\mathrm{a}}$ & 1880 s values & 1880 s values & 1880 s values & 1990s values \\
\hline Orbital forcing ${ }^{\mathrm{b}}$ & 2000 conditions $^{c}$ & 2000 conditions $^{c}$ & 1770 conditions & 2000 conditions \\
\hline Tropospheric aerosols and ozone ${ }^{\mathrm{d}}$ & 1880 s values & 1880 s values & 1880s values & 1990s values \\
\hline
\end{tabular}

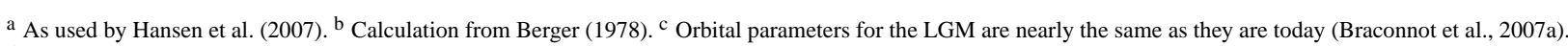

${ }^{\mathrm{d}}$ Aerosols from Koch et al. (2009). Ozone from Shindell et al. (2008).

quadratic upstream tracer advection scheme (Prather, 1986) for improved consistency with the GCM. We discuss these updates in detail below.

For this work, we prescribe atmospheric methane concentrations, imposing a meridional gradient as summarized in Table 3. The preindustrial and LGM simulations use observed methane values from Antarctic, Andean, and Greenland ice cores in the NOAA National Geophysical Data Center (NGDC) Paleoclimatology Program (http://www. ncdc.noaa.gov/paleo/paleo.html) (Chappellaz et al., 1990; Etheridge et al., 1998; Blunier et al., 1998; Thompson, 1998; Petit et al., 1999; Campen, 2000; Loulergue et al., 2008). Our present-day values are from flask observations of the NOAA Global Monitoring Division database (http://www.esrl.noaa. gov/gmd/) (Dlugokencky et al., 2008). We assume methane is uniformly mixed up to the tropopause in each latitudinal band. In the present day and preindustrial, methane increases with increasing latitude in the Northern Hemisphere, reflecting its terrestrial source. The record of tropical methane exists from a single ice core and implies that tropical methane at the LGM maintained preindustrial levels. This ice core was likely contaminated by in situ methanogenic production (Campen et al., 2003), and it is unlikely that a gas with a chemical lifetime of 10 years could maintain such a large tropical-extratropical gradient. We therefore assume tropical methane to be $4 \%$ higher than recorded for Antarctica. This is similar to the present-day gradient, and consistent with earlier model studies of LGM methane (Kaplan et al., 2006) and wetland emissions (Weber et al., 2010).

We calculate stratospheric ozone online in GEOS-Chem following the Linoz linearized chemical scheme (McLinden et al., 2000), with coefficients appropriate for stratospheric chemistry in the LGM (Rind et al., 2009) and the preindustrial (C. McLinden, personal communication, 2009). GEOS-Chem typically uses satellite observations of total
Table 3. Methane mixing ratios prescribed in GEOS-Chem [ppbv].

\begin{tabular}{lrrrr}
\hline & $90-30^{\circ} \mathrm{S}$ & $30^{\circ} \mathrm{S}-0^{\circ}$ & $0^{\circ}-30^{\circ} \mathrm{N}$ & $30-90^{\circ} \mathrm{N}$ \\
\hline Present day $^{\mathrm{a}}$ & 1690 & 1700 & 1760 & 1810 \\
Preindustrial $^{\mathrm{b}}$ & 710 & 725 & 725 & 760 \\
LGM $^{\mathrm{b}}$ & 370 & 385 & 385 & 375 \\
\hline
\end{tabular}

${ }^{a}$ Present-day values from flask samples of the NOAA Global Monitoring Division (GMD) database. ${ }^{\mathrm{b}}$ Preindustrial and LGM are mean values from ice-core records in the NOAA National Geophysical Data Center (NGDC) Paleoclimatology Program, except for the tropical LGM, which is assumed to be $4 \%$ higher than Antarctic methane.

ozone columns to determine the attenuation of shortwave radiation in its calculation of tropospheric photolysis rates. Our use of Linoz allows for calculation of photolysis rates more consistent with changing climate and chemical conditions.

In addition to ozone, we also calculate an array of 20+ other species in the stratosphere to account for chemical fluxes across the tropopause. For example, the stratosphere is a net source of $\mathrm{NO}_{\mathrm{x}}$ into the troposphere and a net sink of tropospheric CO. Stratospheric concentrations of these species are calculated from monthly climatological 3-D production rates and loss frequencies archived from the Global Modeling Initiative (GMI) CTM driven by MERRA assimilated meteorology for 2004-2010 (Allen et al., 2010; Duncan et al., 2007; Considine et al., 2008) and re-gridded to the ModelE grid. We approximate the paleo-stratosphere by scaling the production rates of $\mathrm{NO}_{\mathrm{x}}$ and $\mathrm{HNO}_{3}$ by the ratio of the primary stratospheric nitrogen precursor $\left(\mathrm{N}_{2} \mathrm{O}\right)$ observed in NOAA/NGDC ice cores (preindustrial/present $=0.83 ; \mathrm{LGM} /$ present $=0.77$ ) (Fluckiger et al., 2002), and similarly for $\mathrm{CO}$ by the ratio of ice-core methane (preindustrial/present $=0.41$; $\mathrm{LGM} /$ present $=0.32$ ). Bromine species are the exception to the linearized treatment, and stratospheric concentrations are 
instead prescribed as described by Parrella et al. (2012) and do not change between climates.

To reach equilibrium with respect to stratospheretroposphere exchange, each scenario was initialized over 10 years, repeatedly using the first year of archived meteorology. Simulations for analysis use the three remaining years in each climate scenario.

\subsection{Evaluation of present-day simulation}

We evaluate the ICECAP present-day simulation against a suite of sonde, aircraft, satellite, and surface measurements of trace gases, aerosols, and radionuclides, and we also compare ICECAP with the standard GEOS-Chem driven by assimilated meteorology (GEOS4 and GEOS5). We refer the reader to the supplemental materials for the details, and summarize here. Tropospheric vertical mixing performs better than, or on par with, the GEOS simulations as inferred by comparisons to observed vertical profiles of ${ }^{222} \mathrm{Rn}$ and surface ratios of ${ }^{7} \mathrm{Be} /{ }^{210} \mathrm{~Pb}$. Stratospheric age of air reaches 45 years by $35 \mathrm{~km}$ in our simulations, 1-2 years longer than either GEOS simulation, but in better agreement with observations (Waugh and Hall, 2002). We find a tropospheric residence time for ${ }^{210} \mathrm{~Pb}$-containing aerosols against deposition of $7.2 \mathrm{~d}$, within the range of previous model studies: 6.512.5 d (Turekian et al., 1977; Lambert et al., 1982; Balkanski et al., 1993; Koch et al., 1996; Guelle et al., 1998a, b; Liu et al., 2001).

Our simulated methyl chloroform $\left(\mathrm{CH}_{3} \mathrm{CCl}_{3}\right)$ lifetime against loss from tropospheric $\mathrm{OH}$ is 5.5 years, which is close to the $6.0_{-0.4}^{+0.5}$ years inferred from observations by Prinn et al. (2005), and comparable to recent multi-model estimates of $5.7 \pm 0.9$ years (Naik et al., 2013). The methane lifetime against tropospheric $\mathrm{OH}$ is 10.4 years (cf. Sect. 7), which matches the best estimate of $10.2_{-0.7}^{+0.9}$ years from Prinn et al. (2005), recent multi-model estimates of $10.2 \pm 1.7$ (Fiore et al., 2009) and 9.8 \pm 1.6 years (Voulgarakis et al., 2013), and an observationally derived estimate of $11.2 \pm 1.3$ years (Prather et al., 2012).

The simulated present-day stratospheric columns of ozone (SCO) in our model have a small mean bias of $+1.5 \%$ vs. a 2004-2010 climatology from satellite (Ziemke et al., 2011). However, we overestimate SCO over the poles by $5-50 \%$ due to an overly vigorous Brewer-Dobson circulation, particularly over Antarctica during austral spring ( $>100 \%$ ) as our implementation of Linoz does not include the heterogeneous reactions of the ozone hole. In the troposphere, we underestimate tropical ozone columns by $20 \%$ and overestimate extratropical columns by $45 \%$ vs. satellite climatologies (Ziemke et al., 2011). Comparison with ozonesondes indicates that the tropical bias is in the free- and upper troposphere and not at the surface, and that the extratropical bias is a springtime feature in both hemispheres, consistent with overestimated transport from the stratosphere. Overly vigorous mass fluxes from the stratosphere to the troposphere have histor- ically been a problem with CTMs (e.g., Liu et al., 2001), and some models have prescribed cross-tropopause fluxes of ozone (e.g., Wu et al., 2007). Here we elect to accept the bias in the cross-tropopause flux of ozone in the present day in order to examine the role of the tropical overhead ozone columns on photolysis in different climates. The extratropical biases in ozone will have relatively little impact on the global budget of $\mathrm{OH}$, whose burden is primarily in the tropical lower free troposphere (Spivakovsky et al., 2000).

\section{Climate}

\subsection{Climate forcings}

Table 2 summarizes the different greenhouse gas levels, orbital parameters, topography, and fixed sea ice and sea surface temperatures (SSTs) used to force each of our four simulations. In this section and throughout the paper, we report most changes relative to the state of the preindustrial.

Simulations of LGM climate are sensitive to assumptions about ice sheet topography and tropical SSTs (Rind, 2009), and these assumptions have implications for the chemical composition of the troposphere, as they affect transport, surface emissions, and the surface UV albedo. At the LGM, large permanent land ice sheets 3-4 km thick existed over northern North America (Laurentide and Cordilleran), Greenland, and northwestern Eurasia (Fennoscandian). We use here the reconstruction of ice sheet thickness and extent from Licciardi et al. (1998), which has a lower maximum Laurentide Ice Sheet (LIS) elevation than those in the Paleoclimate Modelling Intercomparison Project (PMIP) studies (Braconnot et al., 2007a, 2012). Ullman et al. (2013) evaluated the sensitivity of the resulting LGM climate in ModelE to two different ice-sheet reconstructions, including Licciardi et al. (1998). They concluded that the lower maximum LIS elevation led to cooler temperatures in the northern latitudes. The accumulation of water in terrestrial ice sheets caused sea levels to drop $120 \mathrm{~m}$, exposing an additional $3 \%$ of the Earth's surface as land, particularly in Southeast Asia and Oceania, the Bering Strait, and the southeastern continental shelf of South America (Clark and Mix, 2002).

Figure 2 shows the annual mean SST distribution used in each past simulation. SSTs in the preindustrial and presentday simulations are from the Hadley Centre sea ice and SST version 1 (HadISST1) data set (Rayner et al., 2003). For the LGM, large uncertainty exists over the extent of cooling of tropical SSTs, which strongly affects LGM dynamics because of its influence on meridional temperature gradients and low-latitude circulation (Rind, 2009). To bound the range of likely conditions, we simulate two potential realizations of the LGM climate driven by different SSTs. For our "warm-LGM" simulation, we use the SST reconstruction from the "Climate: Long range Investigation, Mapping, and Prediction" project (CLIMAP, 1976), with an average 

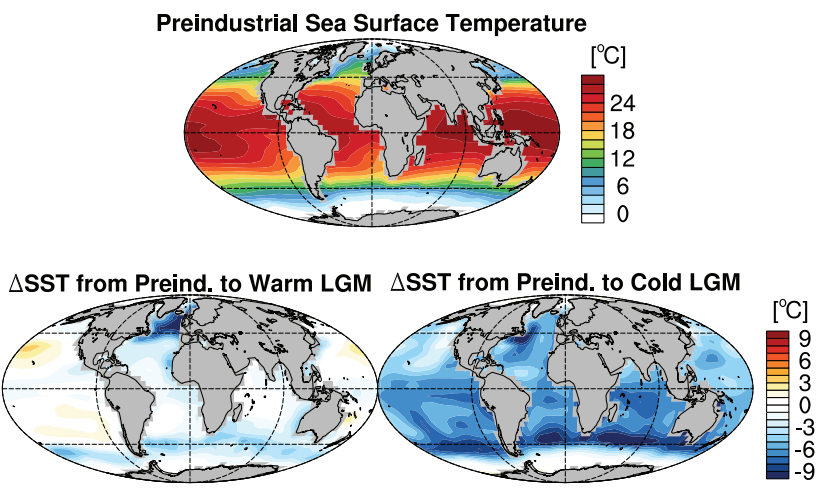

Fig. 2. Top panel shows preindustrial sea surface temperature (SST), as reconstructed by proxies (Rayner et al., 2003). Bottom two panels are the absolute changes in SST during the warm LGM (bottom left; CLIMAP, 1976) and cold LGM (bottom right; Webb et al., 1997) scenarios, relative to the preindustrial, with the LGM coastlines and ice sheets. The difference plots share a common color bar. The change in SST from the preindustrial to the present day is relatively small (not shown).

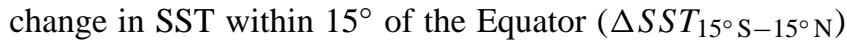
of $-1.2^{\circ} \mathrm{C}$. The CLIMAP reconstruction indicates that much of the subtropical Pacific was warmer in the LGM than in the preindustrial, a controversial result (e.g., Rind and Peteet, 1985). For our "cold-LGM" simulation, we use SSTs

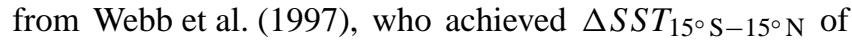
$-6.1^{\circ} \mathrm{C}$ by imposing an ocean heat transport flux in the GISS GCM. The recent "Multiproxy Approach for the Reconstruction of the Glacial Ocean surface" project (MARGO Project Members, 2009) concluded that the SST change was likely colder than that implied by the CLIMAP reconstruction

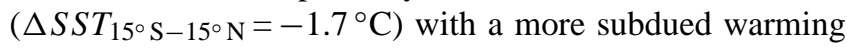
of the subtropical Pacific gyres, but not as cold as in Webb et al. (1997). These changes at the LGM are all greater in

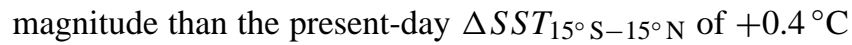
relative to the preindustrial.

\subsection{Climate results}

Table 4 shows mean values for the globe and large zonal bands of meteorological variables in each simulated climate scenario. Relative to the preindustrial, surface air temperatures are 1.4 and $6.8^{\circ} \mathrm{C}$ colder in the warm-LGM and cold-LGM scenarios, respectively, driven by the decreases in greenhouse gases and SSTs and the increase in topography (Fig. 3, left column). The changes in surface temperature to the LGM are much greater in magnitude than the simulated $0.5^{\circ} \mathrm{C}$ increase from the preindustrial to the present day (not shown). Tropospheric water vapor is highly sensitive to temperature (e.g., Held and Soden, 2006; Sherwood et al., 2010), and tropical specific humidity in our warm-LGM and coldLGM scenarios decrease by 10 and $38 \%$ relative to the preindustrial.
Figure 3 also shows the changing distribution of precipitation in each past scenario (right column). The decreases in greenhouse gases and water vapor increase the tropical tropospheric lapse rate at the LGM, reducing the depth and intensity of tropical deep convection (e.g., Sherwood et al., 2010) and weakening the Hadley circulation. With reduced upwelling near the Equator, precipitation decreases in the tropics and increases in the subtropics, especially in the warm pools in the CLIMAP reconstruction.

The residual circulation of the stratosphere also weakens with decreasing levels of greenhouse gases in our simulations. Stratospheric circulation is characterized by net ascent in the tropics and descent in the extratropics, driven by stratospheric breaking of upward-propagating planetary waves of tropospheric midlatitude origin (Holton et al., 1995). The vertical component of the residual circulation $\left(w^{*}\right)$ weakens in magnitude relative to the preindustrial by an average of 16 and $32 \%$, respectively, in the warm-LGM and coldLGM scenarios at $50 \mathrm{hPa}$ in the tropics $\left(12^{\circ} \mathrm{S}-12^{\circ} \mathrm{N}\right)$, and increases by $5 \%$ in the present day. There are corresponding changes in the extratropics. The mass-weighted mean stratospheric age of air (Waugh and Hall, 2002) deduced from an $\mathrm{SF}_{6}$-like tracer in GEOS-Chem is 9-15\% greater in the LGM than the preindustrial, consistent with the weakening residual circulation; the present-day age of air is $8 \%$ lower than the preindustrial.

That the strength of the residual circulation is correlated with greenhouse gas levels is a robust result of GCMs (Garcia and Randel, 2008), including at the LGM (Rind et al., 2001, 2009), although not clearly supported by observations (Engel et al., 2008). The decreased thermal wind shear at the LGM reduces the strength of the subtropical jet, which in turn weakens wave penetration into the stratosphere and leads to deceleration of the residual circulation relative to the preindustrial; the converse holds for the preindustrial to present (Shepherd and McLandress, 2011). Weakened tropical deep convection at the LGM and increased static stability about the tropopause from stratospheric radiative warming also impedes mixing across the tropopause. In addition, the tropopause height decreases in each colder climate; in the cold-LGM scenario it is $2 \mathrm{~km}$ lower than in the preindustrial. The slowing of the residual circulation of the stratosphere together with decreases in tropopause height during the LGM contribute toward enhancement of the SCO and have implications for photolysis rates in the tropical troposphere, as we describe in Sect. 5.1.

\subsection{Evaluation of simulated LGM climate}

Figure 4 demonstrates that our GISS ModelE climate simulations for the LGM are in broad agreement with other LGM model studies and an independent reconstruction of regional LGM climate from pollen records. The left panels compare the zonal mean temperature and precipitation changes of our two LGM simulations to the mean and range of those values 


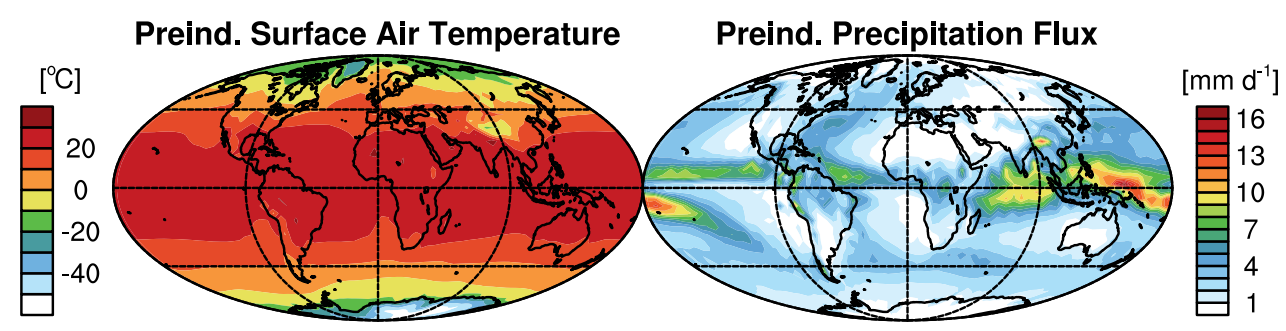

$\Delta \mathrm{T}_{\mathrm{s}}$ from Preind. to Warm LGM $\Delta$ Precip. from Preind. to Warm LGM

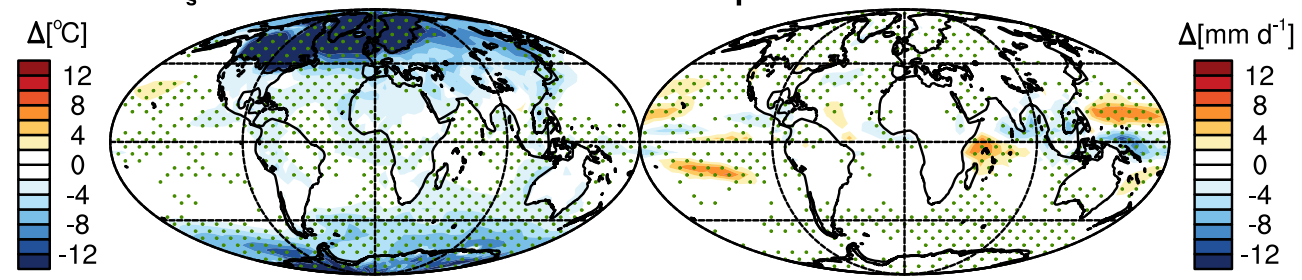

$\Delta \mathrm{T}_{\mathrm{s}}$ from Preind. to Cold LGM $\Delta$ Precip. from Preind. to Cold LGM

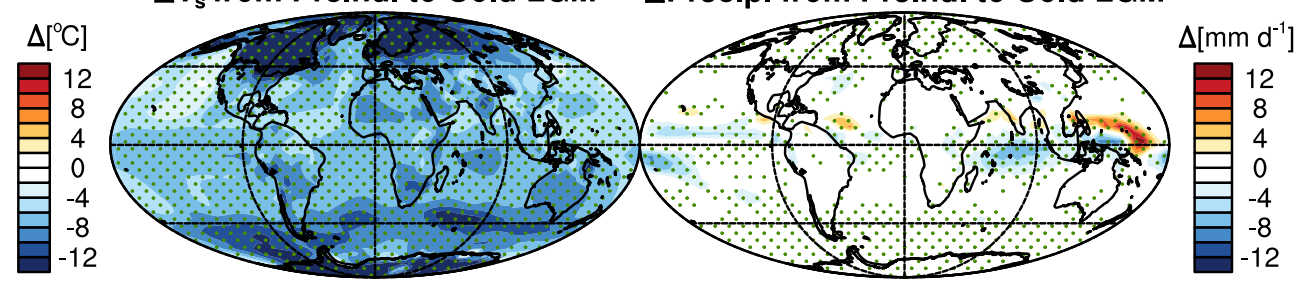

Fig. 3. Simulated surface air temperatures (left column, ${ }^{\circ} \mathrm{C}$ ) and precipitation fluxes (right column, $\mathrm{mm} \mathrm{d}^{-1}$ ). Top panels: preindustrial conditions. Bottom panels, absolute change from preindustrial to warm-LGM (middle row; CLIMAP, 1976) and cold-LGM (bottom row; Webb et al., 1997) scenarios. Both difference plots share a common color bar for each variable. The green dots indicate regions with significant changes, as determined by a Student's $t$ test with degrees of freedom adjusted for autocorrelation (Wilks, 2011). The changes relative to the preindustrial in present-day surface temperatures and precipitation fluxes are small, and significant only at the poles and over small areas of the tropics, respectively (not shown).

Table 4. Climate results for the four scenarios.

\begin{tabular}{|c|c|c|c|c|c|c|c|c|c|c|c|c|c|c|c|c|}
\hline \multirow[b]{3}{*}{ Simulated variable ${ }^{\mathrm{a}}$} & \multicolumn{8}{|c|}{ Last Glacial Maximum (21 ka) } & \multirow{2}{*}{\multicolumn{4}{|c|}{ Preindustrial }} & \multirow{2}{*}{\multicolumn{4}{|c|}{ Present day }} \\
\hline & \multicolumn{4}{|c|}{ Cold LGM } & \multicolumn{4}{|c|}{ Warm LGM } & & & & & & & & \\
\hline & $\mathrm{G}$ & $\mathrm{SH}$ & $\mathrm{T}$ & $\mathrm{NH}$ & G & SH & $\mathrm{T}$ & $\mathrm{NH}$ & G & SH & $\mathrm{T}$ & NH & G & SH & $\mathrm{T}$ & $\mathrm{NH}$ \\
\hline Surface air temperature $\left[{ }^{\circ} \mathrm{C}\right]$ & 6.1 & -3.7 & 19.2 & -2 & 10.7 & 1.5 & 24.6 & 0.8 & 14.3 & 5.4 & 26 & 7.4 & 14.9 & 6 & 26.5 & 8 \\
\hline Specific humidity $\left[\mathrm{g} \mathrm{kg}^{-1}\right]$ & 1.8 & 1.3 & 1.8 & 1.8 & 2.6 & 1.7 & 2.6 & 2.6 & 2.9 & 2 & 2.9 & 2.9 & 3 & 2.1 & 3 & 3 \\
\hline Tropopause pressure $[\mathrm{hPa}]$ & 151 & 196 & 98 & 180 & 135 & 173 & 80 & 172 & 126 & 165 & 75 & 158 & 123 & 160 & 73 & 155 \\
\hline Precipitation rate $\left[\mathrm{mm} \mathrm{d}^{-1}\right]$ & 2.4 & 1.6 & 3.5 & 1.7 & 2.8 & 2 & 4.2 & 1.9 & 3 & 2.3 & 4.3 & 2.1 & 3 & 2.3 & 4.3 & 2.1 \\
\hline Ground albedo [\%] & 21 & 29 & 9 & 28 & 20 & 26 & 9 & 30 & 14 & 18 & 8 & 20 & 14 & 17 & 8 & 19 \\
\hline Land coverage [\%] & 33 & 17 & 27 & 56 & 33 & 17 & 27 & 56 & 29 & 16 & 24 & 47 & 29 & 16 & 24 & 47 \\
\hline Land ice coverage [\%] & 7 & 9 & 0 & 16 & 7 & 9 & 0 & 16 & 3 & 9 & 0 & 2 & 3 & 9 & 0 & 2 \\
\hline Ocean/lake ice coverage [\%] & 11 & 31 & 0 & 7 & 10 & 24 & 0 & 9 & 5 & 8 & 0 & 8 & 4 & 7 & 0 & 7 \\
\hline Total cloud cover [\%] & 58 & 69 & 48 & 62 & 57 & 64 & 49 & 61 & 58 & 63 & 51 & 61 & 59 & 63 & 52 & 63 \\
\hline Cloud top pressure $[\mathrm{hPa}]$ & 616 & 667 & 579 & 616 & 585 & 640 & 535 & 601 & 570 & 616 & 536 & 570 & 574 & 616 & 540 & 577 \\
\hline Elevation above sea level [m] & 341 & 271 & 170 & 646 & 341 & 271 & 170 & 646 & 238 & 218 & 145 & 386 & 238 & 218 & 145 & 386 \\
\hline Surface wind speed $\left[\mathrm{m} \mathrm{s}^{-1}\right]$ & 5.5 & 6.9 & 5.1 & 4.5 & 5.4 & 7.1 & 4.8 & 4.5 & 5.3 & 6.9 & 4.7 & 4.7 & 5.3 & 6.9 & 4.7 & 4.7 \\
\hline Stratospheric age of air ${ }^{\mathrm{b}}$ [years] & 1.64 & & & & 1.55 & & & & 1.43 & & & & 1.31 & & & \\
\hline
\end{tabular}

a Annual multi-year tropospheric mean values for the globe $(\mathrm{G})$, Southern Hemisphere $\left(\mathrm{SH}, 90-23^{\circ} \mathrm{S}\right)$, tropics (
${ }^{\mathrm{b}}$ Mass-weighted mean stratospheric age of air (Waugh and Hall, 2002), calculated with an $\mathrm{SF}_{6}$-like inert tracer.

in the models participating in PMIP2 (Braconnot et al., $2007 \mathrm{a}, \mathrm{b})$. Each of the seven models that simulated the LGM for PMIP2 had a fully coupled ocean-atmosphere, and did not prescribe SSTs as we do here. Our LGM scenarios bound the PMIP2 ensemble mean change of $-2.3^{\circ} \mathrm{C}$ in the tropics relative to the preindustrial. Our simulations find decreases in zonal mean precipitation of $10-50 \%$ within $10^{\circ}$ of the Equator, and of $10-90 \%$ within $40^{\circ}$ of the poles, as well as little 
(a) Change from preindustrial in mean surface air temperature $\left[{ }^{\circ} \mathrm{C}\right]$

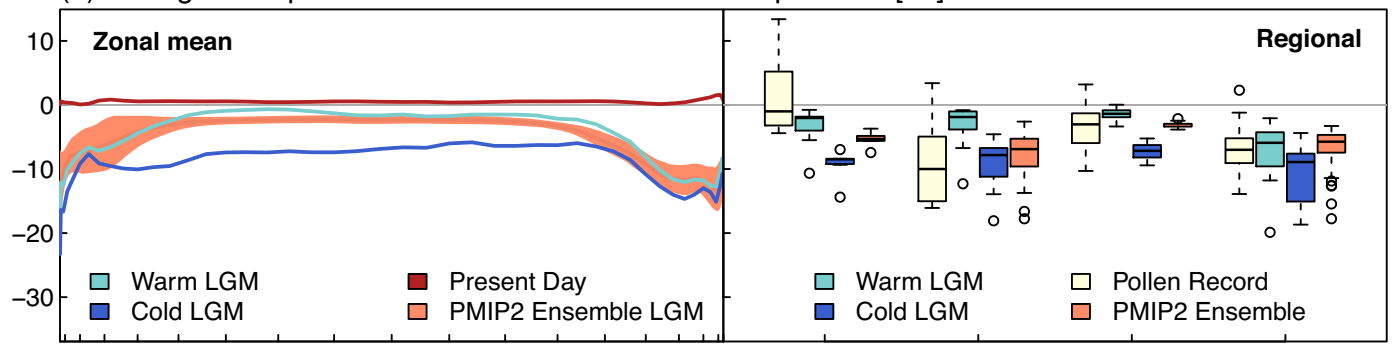

(b) Change from preindustrial in mean precipitation flux $\left[\mathrm{mm} \mathrm{d}^{-1}\right]$

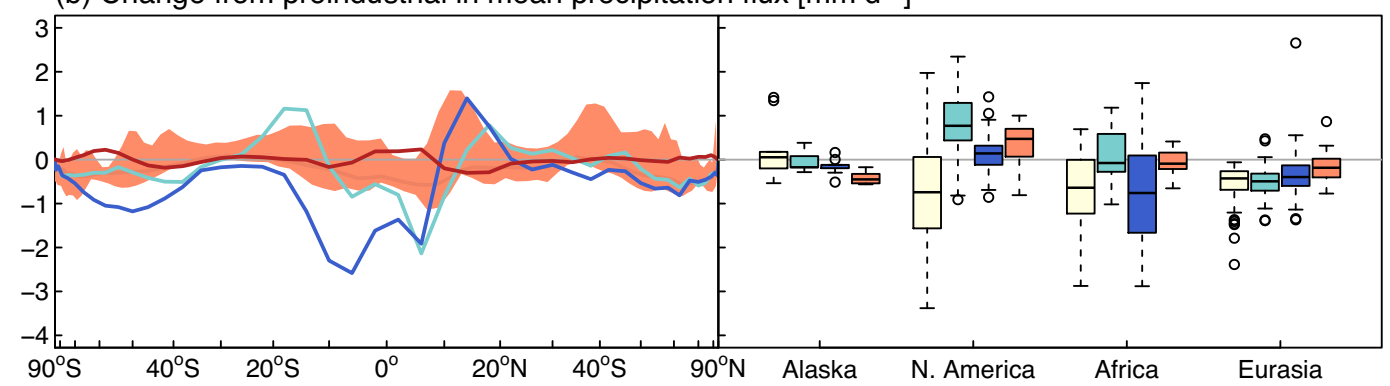

Fig. 4. Evaluation of climate changes for (a) mean surface temperature and (b) zonal mean precipitation flux. The left panels compare our ModelE simulations to the range of zonal mean changes from the preindustrial in the Paleoclimate Multimodelling Intercomparison Project Phase II (PMIP2; Braconnot et al., 2007a). The latitudinal axis is weighted by relative zonal area. The right panels compare our simulation to the pollen-based climate reconstruction from Bartlein et al. (2011) using box-and-whisker plots; dots indicate outliers. The above study used the present day as its baseline, and we follow that convention here. We sample our simulations and the PMIP2 ensemble at the locations of the sediment core measurements.

change in the midlatitudes as in the mean of the PMIP2 ensemble. Precipitation increases up to $25-33 \%$ in the tropics poleward of the Equator in our simulations, where the PMIP2 ensemble mean is zero. Our zonal mean LGM precipitation changes are of greater magnitude than the range of PMIP2.

Figure 4 also compares our modeled results and those of PMIP2 to an inverse reconstruction of regional climate using paleoecological archives by Bartlein et al. (2011). Temperature changes in the warm-LGM simulation relative to the preindustrial better match values inferred from the pollen data than do those in the cold-LGM simulation, with mean absolute biases of 4.4 and $5.1{ }^{\circ} \mathrm{C}$, respectively (the PMIP2 bias is $3.5^{\circ} \mathrm{C}$ ). Both PMIP2 and our simulations have difficulty in matching the inferred changes in precipitation, except over Africa, where the cold LGM performs well. The pollen record has a small sample size ( $n=98$ at the LGM) and a limited geographic distribution, but does provide some confidence in our choice of LGM scenarios as brackets of a range of probable climates.

\section{Tropospheric emissions}

Figure 5 summarizes the gas-phase emissions and Fig. 6 the direct and precursor aerosol emissions in our different simulations. Wherever possible, emissions respond to changing meteorology from the GCM, as described below. We test the sensitivity of our results to three different emission scenar- ios in the preindustrial and LGM atmospheres: a low-fire and a high-fire scenario, which together span the range of estimated past fire magnitudes (Sect. 4.6), and a scenario in which we fix the total lightning source in all climates to compare to our other simulations in which total lightning changes with climate (Sect. 4.5).

\subsection{Anthropogenic}

Present-day anthropogenic emissions from fuel combustion, agriculture, and industry are prescribed from the Emission Database for Global Atmospheric Research (EDGAR) base inventory for 2000 (Olivier, 2001), overwritten with regional inventories for the United States (EPA NEI99), Canada (CAC), Mexico (BRAVO; Kuhns et al., 2005), Europe (EMEP; Auvray and Bey, 2005), and South and East Asia (Streets et al., 2003, 2006). These inventories all have monthly variability, some with additional weekly cycles. Biofuel emissions (Yevich and Logan, 2003) and aircraft emissions are constant. All emissions are scaled as described by van Donkelaar et al. (2008) to 1995 values for our presentday simulation. Our preindustrial and LGM simulations assume no anthropogenic emissions aside from a small biofuel burning source in the preindustrial that is $45 \%$ of the present-day value, estimated by scaling and distributing the 1850 country-level inventory from Fernandes et al. (2007) by the grid cell level of population between 1770 and 1850 


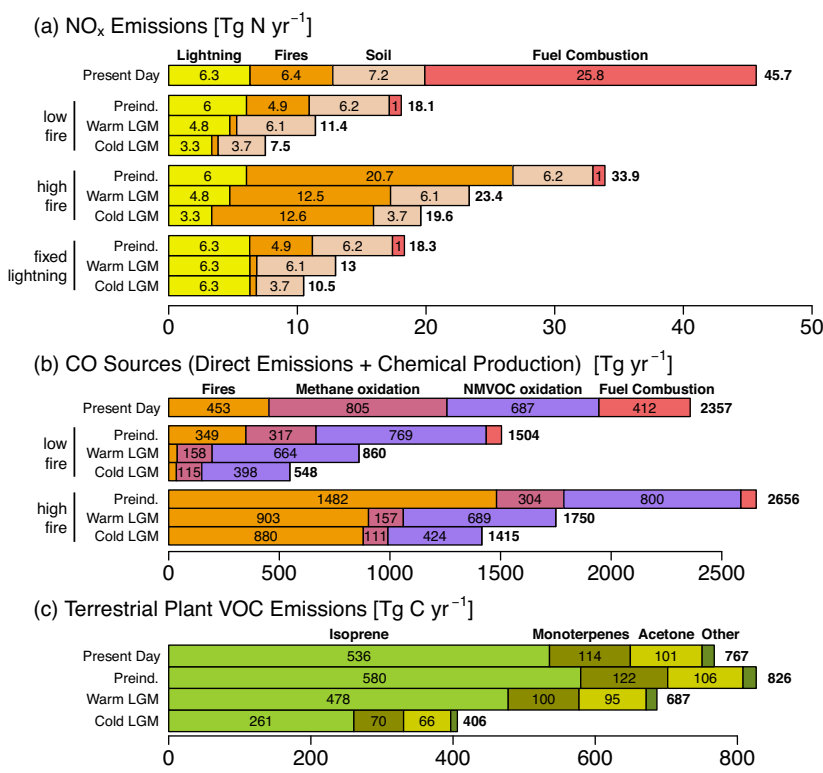

Fig. 5. Gas-phase emissions used for each climate scenario. We test two different fire emission scenarios, a high-fire scenario with past fire emissions from the LPJ-LMfire model (Pfeiffer et al., 2013), and a low-fire scenario in which we scale the model output by sediment records of charcoal accumulation rates (Power et al., 2008). We also perform a fixed lightning suite of simulations in which we scale the total lightning $\mathrm{NO}_{\mathrm{x}}$ source to be constant in different climates.

from the History Database of Global Environment (HYDE v3.1; Klein Goldewijk et al., 2011). Anthropogenic emissions since the preindustrial yield large perturbations to the tropospheric budgets of reactive nitrogen, carbon, and sulfur (Fig. 5 and Fig. 6), predominantly in the northern midlatitudes.

\subsection{Biogenic - land}

Terrestrial plant emissions of VOCs in GEOS-Chem follow the MEGAN scheme, in which each model grid cell is assigned a base emission rate based on its local vegetation. MEGAN adjusts these local base emission rates by applying scaling factors that are time-varying functions of photosynthetically available radiation (PAR), leaf area index (LAI), and a 15-day moving average of recent surface air temperature (Guenther et al., 1995, 1999, 2000, 2006, 2012). Emissions respond positively to increases in each driving variable. For all scenarios in this study, we calculate the base biogenic VOC emissions using the PFT distributions from BIOME4-TG. To derive these emissions, we first perform a multiple regression, mapping the default distribution of MEGAN version 2.1 emission factors onto the present-day PFT distribution in BIOME4-TG. We then apply the resulting emission factors, shown in Table 5, onto the distribution of PFTs calculated by BIOME4-TG for the preindustrial and LGM climates.
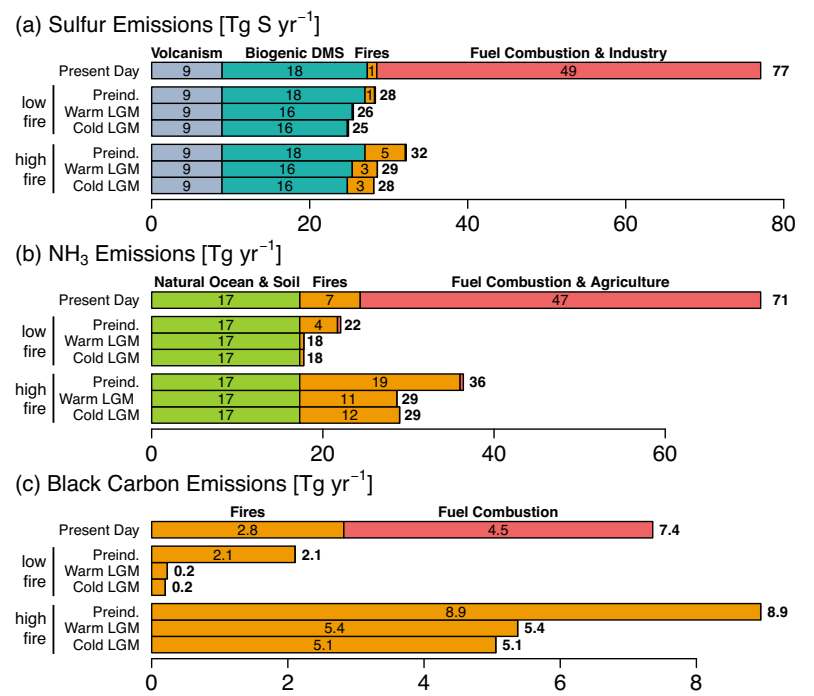

(d) Organic Carbon Emissions [ $\mathrm{Tg} \mathrm{yr}^{-1}$ ]

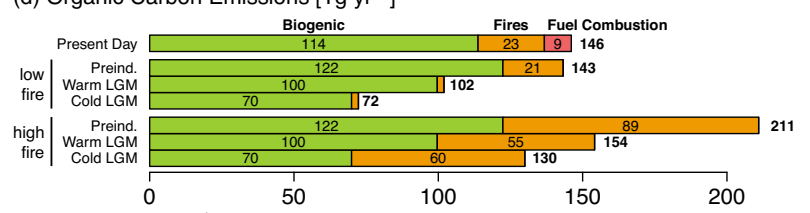

(e) Sea Salt $\left[\mathrm{Tg} \mathrm{yr}^{-1}\right]$

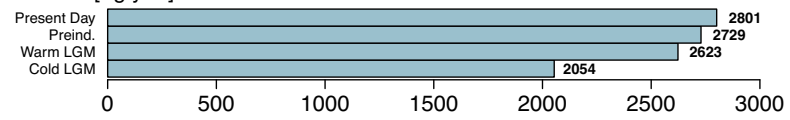

Fig. 6. Same as Fig. 5 but for aerosol precursor emissions.

Figure $5 c$ shows the resulting biogenic emissions from our approach, and Fig. 7a the spatial distribution of changes in isoprene emissions between the different climate simulations. Global terrestrial plant emissions decrease by $7 \%$ in the present day relative to the preindustrial because of large-scale conversion of natural vegetation types to modern croplands (which have lower VOC yields), particularly over southern Brazil and northern India. At the LGM, terrestrial plant emissions decrease by 17 and $51 \%$ relative to the preindustrial in our warm-LGM and cold-LGM scenarios, respectively, predominantly driven by decreases over South America and Africa. These decreases are caused in part by a simulated reduction in tropical broadleaf forests and LAI in the colder and drier tropics (especially in the Amazon and Congo in the cold-LGM scenario), but the driving factor is predominantly the leaf-temperature effect. Hence, we simulate severe reduction in plant emissions of VOCs in the coldLGM scenario with its $>6^{\circ} \mathrm{C}$ of cooling in tropical surface temperatures. However, additional land area exposed on the Sunda and Gulf of Carpentaria continental shelves causes a large regional increase in plant emissions that is stronger in the warm-LGM scenario due to warmer temperatures and increased PAR from decreased cloud cover than in the coldLGM scenario. Our LGM results span the range of previous estimates: Valdes et al. (2005) simulated a $50 \%$ reduction in 
Table 5. Biogenic emission factors used for plant functional types in the dynamic vegetation model BIOME4-TG.

\begin{tabular}{lrrr}
\hline & \multicolumn{3}{c}{ Base emission factor $\left(\mu \mathrm{g}\right.$ molecule $\left.\mathrm{m}^{-2} \mathrm{~h}^{-1}\right)$} \\
BIOME4-TG PFT & Isoprene & Monoterpenes & Acetone \\
\hline Tropical evergreen trees & 5650 & 700 & 2.4 \\
Tropical drought-deciduous trees (raingreens) & 4347 & 535 & 4.1 \\
Temperate broadleaved evergreen trees & 5594 & 575 & 33 \\
Temperate deciduous trees & 4780 & 670 & 53 \\
Cool conifer trees & 3685 & 622 & 19 \\
Boreal evergreen trees & 3155 & 747 & 208 \\
Boreal deciduous trees & 3603 & 533 & 29 \\
C3/C4 temperate grass plant type & 1919 & 170 & 35 \\
C4 tropical grass plant type & 4396 & 475 & 3.9 \\
C3/C4 woody desert plant type & 2364 & 107 & 6.3 \\
Tundra shrub type & 3689 & 319 & 61 \\
Cold herbaceous type & 1677 & 162 & 24 \\
Lichen/forb type & 1492 & 111 & 14 \\
Crops & 407 & 163 & 0.0 \\
\hline
\end{tabular}

biogenic VOC emissions relative to the preindustrial, Kaplan et al. (2006) a $33 \%$ reduction, and Adams et al. (2001) a $29 \%$ reduction.

Emissions of $\mathrm{NO}_{\mathrm{x}}$ from soil microbial activity follow the parameterization of Yienger and Levy (1995) as implemented by Wang et al. (1998) and are dependent on land cover type, precipitation, and temperature. The parameterization yields $7.2 \mathrm{Tg} \mathrm{N}_{\text {year }}{ }^{-1}$ in the present day, which is higher than GEOS-Chem driven by GEOS4 meteorology (5.6 $\mathrm{Tg} \mathrm{N}_{\text {year }}{ }^{-1}$ ), but lower than recently developed parameterizations (8.6-10.7 Tg N year ${ }^{-1}$; Steinkamp and Lawrence, 2011; Hudman et al., 2012). Present-day emissions are $16 \%$ higher than the preindustrial, mostly reflecting the use of fertilizers (Fig. 5a). Soil emissions decrease in each successively colder past climate simulation, driven by the associated decreases in precipitation and surface temperature. In the warm LGM, decreases in precipitation and temperature are offset by additional tropical land mass, and global soil emissions decrease by only $2 \%$ relative to the preindustrial. In the cold LGM, large decreases in temperature and precipitation (especially over southern Brazil) lead to a $40 \%$ decrease in global soil emissions relative to either the preindustrial or warm LGM.

\subsection{Biogenic - ocean}

Phytoplankton and bacteria activity in the mixed layer of the ocean may represent a local source or sink of acetone to the atmosphere. We assume constant ocean acetone concentrations in all climates $(15 \mathrm{nM})$, but allow the sign and magnitude of the ocean-atmosphere flux to vary locally with surface temperature and atmospheric concentration as described by Fischer et al. (2012). In all scenarios, the ocean acts as a net sink for acetone.
Biogenic production of dimethyl sulfide (DMS) is represented in the model as the product of seawater DMS concentrations and sea-to-air transfer velocities (Park et al., 2004). We use distributions of surface ocean concentrations of DMS from Kettle et al. (1999) in all climates, but transfer velocities are parameterized as a function of SST and surface wind speeds (Nightingale et al., 2000a, b). At the LGM, cooler SSTs together with our assumption that no production occurs beneath sea ice yield an $11 \%$ reduction in DMS emissions relative to either the preindustrial or present day (Fig. 6a). Our $84 \%$ reduction in DMS emitted from the Southern Ocean in the warm-LGM scenario is somewhat greater than the $55 \%$ reduction simulated by Castebrunet et al. (2006), who also used the CLIMAP SST/sea-ice reconstruction and held the Kettle et al. (1999) distribution constant, but used a different transfer velocity scheme and a different climate model.

Bromocarbon emissions from oceanic macroalgae and phytoplankton are the dominant bromocarbon precursors for tropospheric $\mathrm{Br}_{\mathrm{y}}$ (Warwick et al., 2006; Law et al., 2007). Emissions are prescribed from Liang et al. (2010) as implemented by Parrella et al. (2012), and remain constant between climate scenarios.

\subsection{Volcanic}

Volcanic emissions of $\mathrm{SO}_{2}$ are from the AEROCOM inventory (Diehl, 2009) as implemented by Fisher et al. (2011) and vary spatially and daily. The emissions are released vertically into the troposphere as in Chin et al. (2000). We apply emissions from a typical recent year (1995) to all scenarios, with $2.5 \mathrm{Tg} \mathrm{S}$ year $^{-1}$ of eruptive emissions and 8.9 $\mathrm{Tg} \mathrm{S}_{\text {year }}{ }^{-1}$ of passive outgassing. Volcanic activity may vary over glacial periods following redistribution of surface 
(a) Plant Isoprene $\left[10^{12} \mathrm{molec} \mathrm{C} / \mathrm{cm}^{2} / \mathrm{s}\right]$

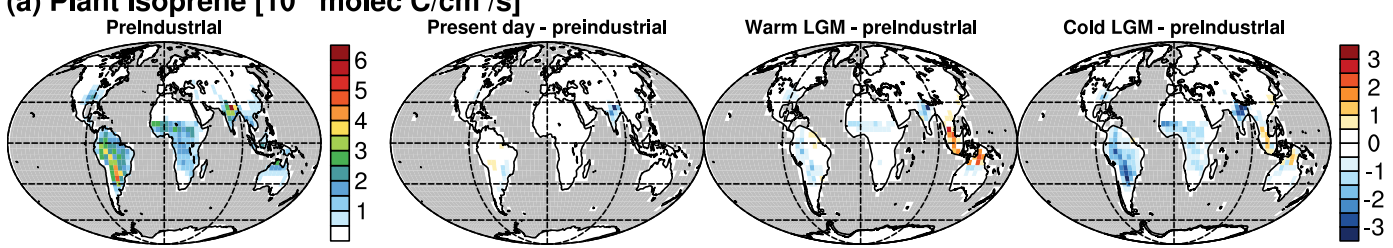

(b) Lightning $\mathrm{NO}_{x}\left[10^{10} \mathrm{molec} / \mathrm{cm}^{2} / \mathrm{s}\right]$
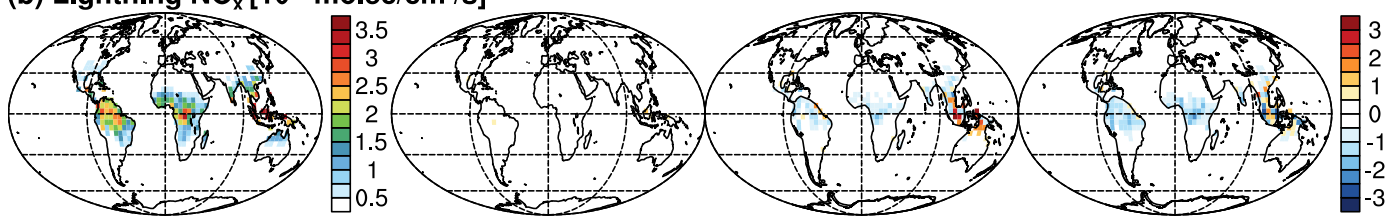

(c) Fire $\mathrm{CO}\left[10^{11} \mathrm{molec} / \mathrm{cm}^{2} / \mathrm{s}\right]$
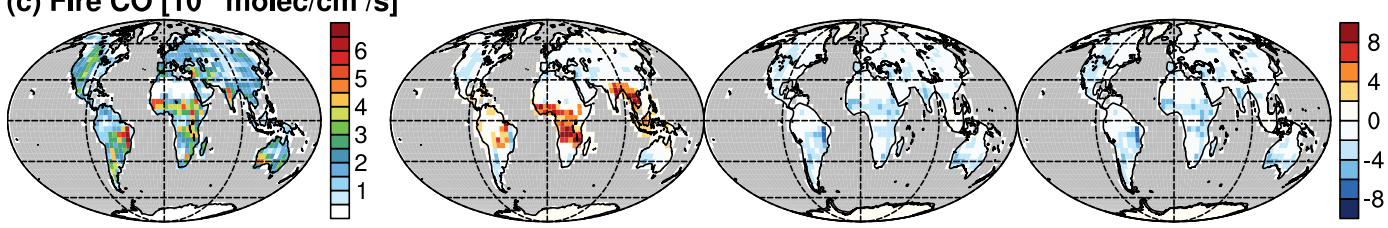

Fig. 7. Spatial distribution of annual mean preindustrial emissions, and the present-day and LGM absolute changes in these emissions relative to the preindustrial for (a) isoprene from terrestrial plants, (b) $\mathrm{NO}_{\mathrm{x}}$ from lightning, and (c) $\mathrm{CO}$ from fires in the low-fire scenario. The difference plots share the common color bars on the right.

mass stresses from ice sheets (Kutterolf et al., 2013), but we do not examine that possibility here.

\subsection{Lightning}

Lightning is a major natural source of $\mathrm{NO}_{\mathrm{x}}$ (Schumann and Huntrieser, 2007). The standard lightning $\mathrm{NO}_{\mathrm{x}}$ source in GEOS-Chem is described by Murray et al. (2012). Lightning flash rates in the model follow the parameterization of Price and Rind $(1993,1992,1994)$ and reflect changes in convective cloud top heights. For the present day, we determine a uniform scaling factor (i.e., 7.0) such that the simulated global mean flash rate matches the 46 flashes s $^{-1}$ observed by satellites (Christian et al., 2003). We use the same scaling factor for all climates, therefore allowing global mean lightning activity to change with changes in deep convection. We assume a uniform production rate of $310 \mathrm{~mol} \mathrm{~N}$ per all flash types (corresponding to $6.3 \mathrm{Tg} \mathrm{N}$ year ${ }^{-1}$ in the present day), and distribute emissions vertically following Ott et al. (2010). This falls within the range of current global models (5.5 $\pm 2.0 \mathrm{Tg} \mathrm{N}_{\text {year }}{ }^{-1}$; Stevenson et al., 2013), and matches a recent top-down estimate of $6.3 \pm 1.4 \mathrm{Tg} \mathrm{N}_{\text {year }}{ }^{-1}$ from multiple satellite constraints (Miyazaki et al., 2013).

Figure $7 \mathrm{~b}$ shows changes in the lightning $\mathrm{NO}_{\mathrm{x}}$ distribution. The Price and Rind $(1993,1992,1994)$ formulation strongly responds to decreases in the vertical extent of deep convection, and lightning activity therefore decreases in each successively colder climate. Relative to the preindustrial, lightning is $5 \%$ more abundant at the present day and 20 and $45 \%$ less abundant in the warm-LGM and cold-LGM scenarios, respectively (Fig. 5a). The primary reductions in lightning abundance at the LGM are simulated over Africa and South America, with only very small reductions in temperate and boreal latitudes, and local increases in lightning over the exposed continental margins in the tropics.

Although lightning is known to be strongly correlated with surface temperatures on diurnal through decadal timescales (Williams et al., 2005), how it may respond to changing meteorology on longer scales is uncertain (Williams, 2005). Therefore we also perform a suite of "fixed lightning" simulations in which we uniformly scale the average $\mathrm{NO}_{\mathrm{x}}$ yield per flash in each climate scenario such that we maintain a constant total lightning $\mathrm{NO}_{\mathrm{x}}$ yield of $6.3 \mathrm{Tg} \mathrm{N}_{\text {year }}{ }^{-1}$.

\subsection{Fires}

Both natural and human-ignited fires have likely played a large role in trace gas emissions since the LGM (Pyne, 2001). For the present day, we prescribe monthly mean emissions of pyrogenic trace gases and aerosols from Yevich and Logan (2003). However, there is large uncertainty in the amount of fire activity in the past. Many previous model studies assumed that preindustrial fire emissions were considerably lower than those estimated for the present; Crutzen and Zimmermann (1991) suggested a $90 \%$ reduction. More recently, a global synthesis of charcoal accumulation rates suggested that preindustrial fire emissions were similar to or slightly higher than those in the present day (Power et al., 2008), while the record of black carbon deposition at Greenland and Antarctica also implies that burning was mostly constant from the preindustrial through to the present (McConnell et al., 2007; Bisiaux et al., 2012). Measurements 
of $\delta^{13} \mathrm{C}$ and $\delta^{18} \mathrm{O}$ in ice-core $\mathrm{CO}$ for Antarctica appear to indicate that southern hemispheric fire emissions were substantially higher in the preindustrial than at present (Wang et al., 2010), but this view is controversial (van der Werf et al., 2013). Fischer et al. (2008) interpreted ice-core measurements of $\delta^{13} \mathrm{CH}_{4}$ in a box model, and determined the pyrogenic source of methane to be roughly constant between the LGM and the preindustrial at $45 \mathrm{TgCH}_{4}$ year $^{-1}$, higher than most estimates of the present-day biomass burning methane source (29-48 $\mathrm{Tg} \mathrm{CH}_{4}$ year $^{-1}$; Bousquet et al., 2011; Chen and Prinn, 2006; Pison et al., 2009; van der Werf et al., 2010), but not taking into account the potential large influence of atomic chlorine (a minor oxidation pathway) on $\delta^{13} \mathrm{CH}_{4}$ (Levine et al., 2011b). The extremely limited charcoal data that exist for the LGM suggest that fire activity was at a historical minimum (Power et al., 2008), but geographic coverage is very poor, and only a small fraction of the continents are represented. Model representations of fire activity show large disagreements in the trends over glacialinterglacial and preindustrial to present-day time horizons (Thonicke et al., 2005; Fischer et al., 2008; Pfeiffer and Kaplan, 2013). Given the wide range of estimates for fire activity since the LGM, we test a range of emissions for each climate, as we describe below.

For all simulations, we use distributions of dry matter consumed per PFT from the LPJ-LMfire model (Pfeiffer et al., 2013) coupled with emission factors from the Global Fire Emissions Database version 3 (GFED3) (van der Werf et al., 2010) for $\mathrm{NO}_{\mathrm{x}}, \mathrm{CO}, \mathrm{SO}_{2}$, black carbon, $\mathrm{OC}$, and 17 additional gas-phase species. We assume emission factors per PFT remain constant in all climates, and do not test their sensitivity to changes in meteorological or geographical conditions. Such sensitivity is still poorly understood on global scales (van Leeuwen and van der Werf, 2011). LPJ-LMfire yields fire emissions in the preindustrial and LGM scenarios that are 3-4 times higher than those for the present day, primarily reflecting the absence of active fire suppression in the preindustrial world and decreases in passive fire suppression due to less fragmentation in the landscape and reduced livestock grazing. These results represent an upper limit of fire activity in the past. For a lower limit, we estimate fire emissions by scaling the LPJ-LMfire total dry matter consumed to match emissions implied by the charcoal accumulation rates from the Global Charcoal Database (preindustrial $=100 \%$ and $\mathrm{LGM}=10 \%$ of the present-day 4.2 Pg year $^{-1}$ dry matter consumed) (Power et al., 2008, 2010; van der Werf et al., 2010). We apply both estimates to GEOS-Chem, and refer to these simulations as the "high-fire" and "low-fire" scenarios in each climate. Totals for these scenarios are shown in Figs. 5 and 6. The model does not simulate online methane chemistry (or methane isotopes), so we are unable to directly compare to ice-core records of $\delta^{13} \mathrm{CH}_{4}$.

Figure $7 \mathrm{c}$ shows the changing distribution of $\mathrm{CO}$ emissions in the low-fire preindustrial emissions scenario. While the total dry matter consumed is the same for the low-fire and present-day simulations, there are changes in the geographic distribution of emissions. Fire activity decreases in the present-day extratropics due to active and passive fire suppression, and increases in the tropics due to deforestation and agricultural practices. As tropical fires have higher emission factors per dry matter consumed (van der Werf et al., 2010), total emissions are higher in the present day by $\sim 25 \%$ relative to the preindustrial, despite dry matter consumed remaining constant. In the high-fire scenario, emissions are lower almost everywhere relative to preindustrial in both the present-day and LGM scenarios (not shown).

\subsection{Wind-driven emissions}

Sea salt aerosol evasion from the ocean is described by Jaeglé et al. (2011), and responds to SSTs and surface wind speeds. Emissions at the present day are $3 \%$ higher than the preindustrial. Emissions at the LGM are $4 \%$ and $25 \%$ lower than the preindustrial, largely reflecting SSTs and extent of sea ice. Debromination of sea salt is an important source of bromine radicals to the troposphere, and responds to sea salt aerosol as described by Parrella et al. (2012); it has been updated with size-dependent bromine depletion factors from Yang et al. (2008). The debromination source increases by $3 \%$ at the present day and decreases by $7-9 \%$ at the LGM relative to the preindustrial. We do not consider here the possible enhancement due to increased particle acidity from present-day anthropogenic emissions, or the reduction with increased alkalinity at the LGM (Sander et al., 2003).

We prescribe monthly mean dust concentrations in GEOS-Chem, as the coarsely resolved surface winds from the GCM are too weak to mobilize a realistic dust burden. We use 3-D mineral dust fields from Mahowald et al. (2006), with LGM burdens $125 \%$ greater than in the preindustrial and present. The drier conditions of the LGM promote large increases in dust mobilized from the expanded Sahara and the Tibetan Plateau relative to the preindustrial and present, as well as from the exposed continental shelf of South America.

\section{Results: changes in the tropospheric oxidants}

Figure 8 shows the tropospheric mean air-mass-weighted concentrations for each of the four major oxidants simulated in each of the four climates (present day, preindustrial, warm LGM, and cold LGM), and three sensitivity studies for the past climates (high fire, low fire, and fixed lightning). For comparison, we also show a present-day simulation driven by assimilated GEOS4 meteorology for 1994-1996 instead of ModelE meteorology. Anthropogenic emissions in the two present-day simulations are identical. We find reduced oxidative capacity relative to the present day in all climates, except for $\mathrm{OH}$ in the fixed lightning LGM simulations, and $\mathrm{H}_{2} \mathrm{O}_{2}$ in the preindustrial high-fire scenario. In general, oxidant 

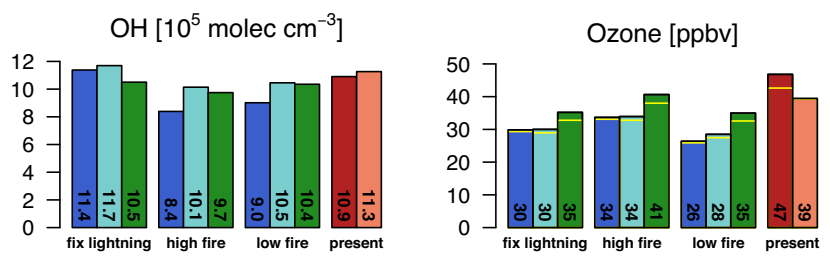

$\mathrm{H}_{2} \mathrm{O}_{2}$ [ppbv]
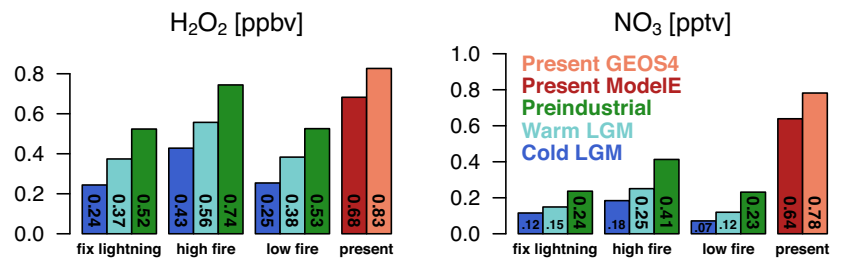

Fig. 8. Tropospheric mean mass-weighted oxidant burdens, calculated with the tropopause determined from the thermal lapse rate. For comparison with ACCMIP (Young et al., 2013), the horizontal yellow lines for ozone show the tropospheric burden calculated using a $150 \mathrm{ppb}$ chemical tropopause.

burdens decrease with decreasing surface temperature, and changes in $\mathrm{OH}$ are relatively small compared to the other oxidants. We discuss these changes in oxidants in more detail below. Unless otherwise indicated, all changes are reported as the mean percentage change \pm standard deviation $(1 \sigma)$ in the 18 pairwise combinations of the 6 LGM simulations relative to the 3 preindustrial ones, and the 3 pairwise combinations of the ModelE present day vs. 3 preindustrial. Comparison with the PMIP2 ensemble and with reconstructions of LGM climate from pollen records (Sect. 3) and ice-core records (Sect. 6) suggest that the low-fire scenarios and the warm-LGM climate are the most likely representations of the past atmospheres of our ensemble members; we refer to their combination as our "best estimate".

\subsection{Hydroxyl radical}

Tropospheric mean $\mathrm{OH}$ for each simulation is shown in the top-left panel of Fig. 8. OH burdens in our ModelE-driven simulations increase by $+7.0 \pm 4.3 \%$ in the present day relative to the preindustrial ( $+5.3 \%$ in our best estimate). The ensemble mean shows little change at the LGM relative to the preindustrial: $+0.5 \pm 12 \%(+1.7 \%$ best estimate). The spread in our estimated $\mathrm{OH}$ change is large, but much less than found by most prior studies (cf. Table 1). OH is largely insensitive to variations in fire emissions. We diagnose these changes below.

Figure 9 shows the global chemical budget for $\mathrm{OH}$ in each simulation. The nonlinear reactions controlling $\mathrm{OH}$ are complicated but well known (e.g., Logan et al., 1981; Spivakovsky et al., 2000; Lelieveld et al., 2002). Primary production is by photolysis of tropospheric ozone in the presence of water vapor, with secondary production from rapid chemical cycling of the $\mathrm{HO}_{\mathrm{x}}$ family $\left(\mathrm{HO}_{\mathrm{x}} \equiv \mathrm{OH}+\mathrm{RO}_{2}\right.$; $\mathrm{RO}_{2} \equiv \mathrm{HO}_{2}+$ organic peroxy radicals). Loss is primar-

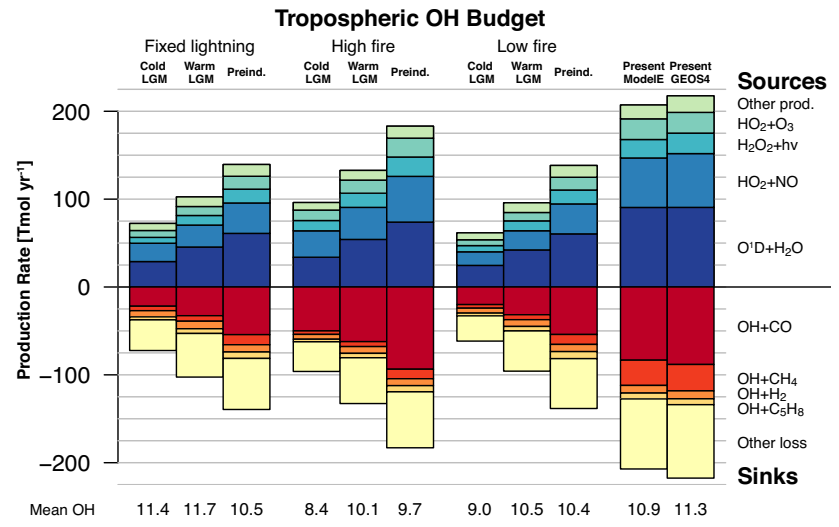

Fig. 9. Global annually averaged chemical production and loss rates of $\mathrm{OH}$ in each simulation by contributing reaction. The numbers along the bottom are tropospheric air-mass-weighted mean $\mathrm{OH}$ $\left(10^{5}\right.$ molecules $\left.\mathrm{cm}^{-3}\right)$.

ily via reaction with $\mathrm{CO}$ in all climates, but reaction with methane, other VOCs, and their degradation products (which include $\mathrm{CO}$ ) are also important. Absolute production and loss rates consistently decrease in each successively colder climate, and do so mostly independently of our different emission scenarios, implying the changes are primarily driven by meteorology. However, the response of mean $\mathrm{OH}$ as seen in Fig. 8 is relatively small compared to the changes in the overall rates of its production and loss reactions.

Present-day mean $\mathrm{OH}$ increases $+7.0 \pm 4.3 \%$ relative to preindustrial levels, which is much less than the perturbations to emissions - e.g., the 35-52\% increase in $\mathrm{NO}_{\mathrm{x}}$. Our results are consistent with the recent multi-model ACCMIP study, which reported a mean $\Delta \mathrm{OH}$ of $-0.6 \pm 8.8 \%$ for $1850-2000$ (Naik et al., 2013). To understand the relatively small impact of anthropogenic emissions on $\mathrm{OH}$, we follow the approach of Wang and Jacob (1998), who derived a linear relationship between $\mathrm{OH}$ and emissions using the steady-state equations of the $\mathrm{NO}_{\mathrm{x}}-\mathrm{HO}_{\mathrm{x}}-\mathrm{CO}-$ ozone system. They found that mean $\mathrm{OH}$ varies with the ratio $S_{\mathrm{N}} /\left(S_{\mathrm{C}}^{3 / 2}\right)$, where $S_{\mathrm{N}}$ represents total $\mathrm{NO}_{\mathrm{x}}$ emissions (mol year ${ }^{-1}$ ) and $S_{\mathrm{C}}$ represents the source of reactive carbon ( $\mathrm{CO}$ and hydrocarbons, mol year $^{-1}$ ). We also find a linear relationship between $\mathrm{OH}$ and $S_{\mathrm{N}} /\left(S_{\mathrm{C}}^{3 / 2}\right)$ in our preindustrial and present-day simulations $\left(R^{2}=0.81 ; n=2\right.$ present-day +3 preindustrial simulations). $\Delta \mathrm{OH}$ is small because $S_{\mathrm{N}} /\left(S_{\mathrm{C}}^{3 / 2}\right)$ has changed little from the preindustrial to the present, as human activity has increased both $S_{\mathrm{N}}$ and $S_{\mathrm{C}}$ (Thompson et al., 1993).

On glacial-interglacial timescales, the dependence of $\mathrm{OH}$ on $S_{\mathrm{N}} /\left(S_{\mathrm{C}}^{3 / 2}\right)$ alone cannot explain the simulated variability ( $R^{2}=0.06 ; n=11$ simulations). Instead, we find linear dependence by including two variables that Wang and Jacob (1998) had assumed remained constant in their derivation: the mean tropospheric ozone photolysis frequency, $J_{\mathrm{O}_{3}}$ $\left(\mathrm{s}^{-1}\right)$, and water vapor concentration, which we represent by 


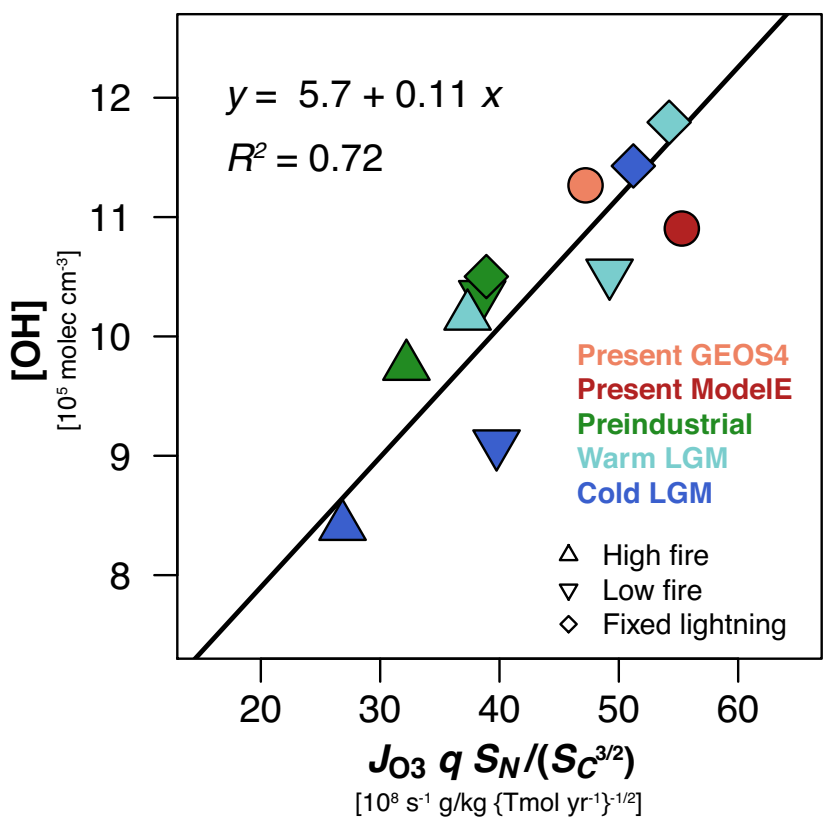

Fig. 10. Global mean $\mathrm{OH}$ concentration in each simulation as a function of $J_{\mathrm{O}_{3}} q S_{\mathrm{N}} /\left(S_{\mathrm{C}}^{3 / 2}\right)$, where $J_{\mathrm{O}_{3}}$ is the mean tropospheric ozone photolysis frequency $\left(\mathrm{s}^{-1}\right), q$ is the tropospheric mean specific humidity $\left(\mathrm{g} \mathrm{kg}^{-1}\right)$, and $S_{\mathrm{N}}$ and $S_{\mathrm{C}}$ are the tropospheric sources of reactive nitrogen ( $\mathrm{Tmol} \mathrm{N}_{\mathrm{Near}}{ }^{-1}$ ) and reactive carbon

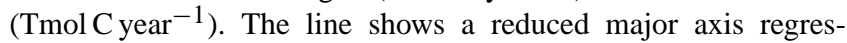
sion fit. $S_{\mathrm{C}}$ is calculated as the sum of emissions of $\mathrm{CO}$ and NMVOCs and an implied source of methane equal to its loss rate. Each molecule of isoprene yields an average 2.5 carbons that react within the gas-phase mechanism; the other NMVOCs have negligible global impact.

specific humidity, $q\left(\mathrm{~g} \mathrm{H}_{2} \mathrm{O} \mathrm{kg} \mathrm{air}{ }^{-1}\right)$, i.e.,

$[\mathrm{OH}] \propto J_{\mathrm{O}_{3}} q S_{\mathrm{N}} /\left(S_{\mathrm{C}}^{3 / 2}\right)$.

This linear relationship explains $72 \%$ of the simulated variability in tropospheric mean $\mathrm{OH}$ across our 11 simulations (Fig. 10). Our simulations indicate that $J_{\mathrm{O}_{3}}$ and $q$ are sufficiently variable on glacial-interglacial timescales to effect changes greater than those from emissions. To first order, $J_{\mathrm{O}_{3}} q$ may be thought of as controlling the variability in primary production of $\mathrm{HO}_{\mathrm{x}}$, and $S_{\mathrm{N}} /\left(S_{\mathrm{C}}^{3 / 2}\right)$ in regulating $\mathrm{HO}_{\mathrm{x}}$ equilibrium partitioning between $\mathrm{OH}$ and $\mathrm{RO}_{2}$, which taken together determine mean $\mathrm{OH}$ (although the ratio $S_{\mathrm{N}} /\left(S_{\mathrm{C}}^{3 / 2}\right)$ also influences ozone production and therefore $\mathrm{HO}_{\mathrm{x}}$ production).

Mean $\mathrm{OH}$ independently varies most in our 11 simulations with the photolysis component $\left(J_{\mathrm{O}_{3}}\right)$ of Eq. (1) $\left(R^{2}=0.26\right)$, although its weak correlation emphasizes the necessity of considering all three factors together. Specific humidity $q$ is a strong function of temperature (Sherwood et al., 2010), decreasing by $23 \%$ in the warm-LGM scenario and $50 \%$ in the cold-LGM scenario, and is more weakly correlated with mean $\mathrm{OH}\left(R^{2}=0.18\right)$.
Changes in $J_{\mathrm{O}_{3}}$ reflect changes in shortwave radiation attenuation through overhead ozone columns, aerosol concentrations, and clouds; overhead ozone accounts for most of the change ( $J_{\mathrm{O}_{3}}$ vs. SCO: $R^{2}=0.85$ ). Total cloud cover does not change sufficiently in our simulations to have a significant impact on global photolysis rates. Over high latitudes in summer at the LGM, increased snow and ice cover over both land and ocean enhance UV surface albedos and thus $J_{\mathrm{O}_{3}}$.

Figure 11 shows the absolute changes in stratospheric columns of ozone in our simulations. Relative to the preindustrial simulation, tropical stratospheric ozone columns have decreased $4-6 \%(10-12$ DU) in the present day, and have increased $3-6 \%(10-12 \mathrm{DU})$ in the warm-LGM and $10-13 \%(26-30$ DU) in the cold-LGM simulations. The increases in tropical overhead ozone at the LGM are driven in the model by (a) reduced catalytic destruction of ozone from reduced stratospheric halogen and $\mathrm{NO}_{\mathrm{x}}$ burdens; (b) the deceleration of the residual stratospheric circulation (cf. Sect. 3.2) that slows the transport of ozone away from the region of net photochemical production in the tropics to the polar stratosphere, which also decreases extratropical SCO; and (c) decreases in the tropical tropopause height, which increases stratospheric mass, especially in the cold-LGM scenario. These increases in stratospheric ozone are slightly offset by the influence of warmer stratospheric temperatures at the LGM. The converse holds true for explaining the preindustrial to present-day changes (increased catalyzed ozone loss, a strengthened residual circulation, and a slight increase in tropopause height). Our results are consistent with Rind et al. (2009), who also simulated increases in stratospheric ozone at the LGM using Linoz online within the GISS III GCM, and with climate-driven changes in stratospheric ozone seen in satellite observations (Neu et al., 2014) and model studies (Hsu and Prather, 2009; Hegglin and Shepherd, 2009) for the present day and near future.

The dependence of $\mathrm{OH}$ on $S_{\mathrm{N}} /\left(S_{\mathrm{C}}^{3 / 2}\right)$ explains why the simulated $\mathrm{OH}$ burden is insensitive to fire emissions but highly sensitive to lightning. Fire emissions of $\mathrm{NO}, \mathrm{CO}$, and VOCs in the model assume fixed emission factors per dry matter consumed (van der Werf et al., 2010), so large absolute differences in burning yield relatively small changes in $S_{\mathrm{N}} /\left(S_{\mathrm{C}}^{3 / 2}\right)$. However, we note that if fire emission factors per species were to vary independently of one another in response to climate, then the fire influence on $\mathrm{OH}$ could be greater. In contrast, lightning and soil microbial activity are large sources of $\mathrm{NO}_{\mathrm{x}}$ with potentially large changes on glacial-interglacial timescales and so can strongly alter $S_{\mathrm{N}} /\left(S_{\mathrm{C}}^{3 / 2}\right)$. Large changes in emissions of biogenic VOCs could also potentially perturb the $S_{\mathrm{N}} /\left(S_{\mathrm{C}}^{3 / 2}\right)$ ratio. However, we find interglacial changes in biogenic VOCs are strongly correlated to soil $\mathrm{NO}_{\mathrm{x}}$ emissions $\left(R^{2}=0.92\right)$, muting the impact of either on $\mathrm{OH}$.

That we simulate small and even negative $\Delta \mathrm{OH}$ at the LGM relative to the preindustrial is contrary to most earlier 

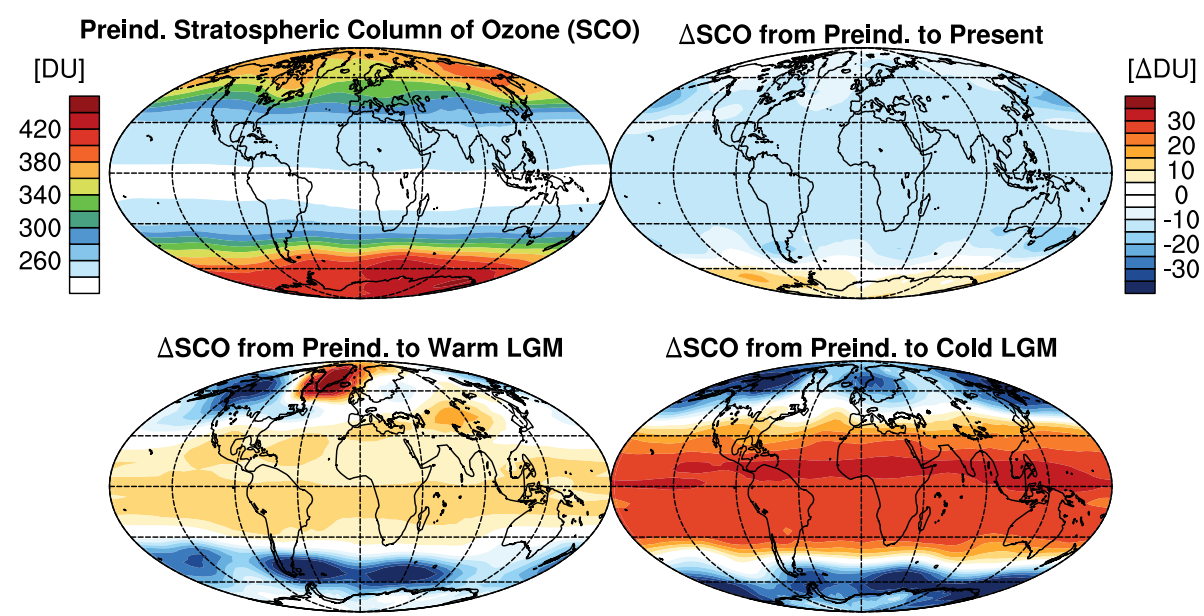

Fig. 11. Preindustrial simulated zonal mean stratospheric ozone columns [DU], and the change in ozone in the present day relative to the preindustrial (top panels). The model does not include the heterogeneous chemistry of the Antarctic ozone hole. Also shown are the changes during the warm and cold simulations of the LGM relative to the preindustrial (bottom panels). The difference plots share a common color bar.

studies (Table 1). Valdes et al. (2005) and Kaplan et al. (2006) simulated $25-28 \%$ increases in $\mathrm{OH}$ at the LGM driven by reductions in biogenic emissions. These two studies favored the influence of biogenic emissions in the context of Eq. (1) by calculating little or no change in $S_{\mathrm{N}}$ across climates, by having smaller values of $S_{\mathrm{N}}$ but simulating slightly larger changes in biogenic emissions than we do at the LGM, and by assuming present-day stratospheric conditions in all climates. Levine et al. (2011c) recently concluded that the temperature effects on $\mathrm{OH}$ loss rates and on specific humidity $q$ are sufficient to cancel out the effects of biogenic NMVOCs on $\mathrm{OH}$ across glacial timescales, more in keeping with our results, though they did not consider the effect of the stratosphere or changing $\mathrm{NO}_{\mathrm{x}}$. Previous LGM studies have neglected the possible influence of the stratosphere, except Karol et al. (1995), who simulated decreases in $\mathrm{OH}$ at the LGM. Equation (1) indicates $\mathrm{OH}$ will increase at the LGM only if the source of $\mathrm{NO}_{\mathrm{x}}$ from lightning (or potentially soils) increases relative to the reference period (as in four of our LGM-preindustrial pairs), or if biogenic VOC emissions decrease sufficiently such that the increase in $S_{\mathrm{N}} /\left(S_{\mathrm{C}}^{3 / 2}\right)$ can overcome the counter-effects of reduced water vapor and increased overhead ozone.

Figure 12 shows the modeled spatiotemporal distribution of $\mathrm{OH}$ concentrations in the preindustrial scenario and the absolute changes in the present-day and LGM scenarios relative to the preindustrial. Only results from the low-fire scenarios are shown, as the other emission scenarios have similar spatiotemporal patterns. Most of the change from the preindustrial to present occurs in the boundary layer over the temperate latitudes of the Northern Hemisphere in summer, reflecting the rise of anthropogenic emissions. At the LGM, the changes in overhead ozone and water vapor decrease $\mathrm{OH}$ throughout most of the tropics, with maximum decreases oc- curring over the land regions where lightning $\mathrm{NO}_{\mathrm{x}}$ decreases the most (Fig. 7b). Decreased production rates in the tropics outweigh the reduction in loss frequencies from reduced $\mathrm{CO}$, methane, and NMVOCs, driving net negative anomalies in most regions in all simulations. One exception is over Sundaland, where increased lightning $\mathrm{NO}_{\mathrm{x}}$ over the exposed continental shelves locally enhances $\mathrm{OH}$. Another exception is over the Indian subcontinent in the cold-LGM scenario, where severe reductions in biogenic emissions also increase $\mathrm{OH}$. In the polar regions, where $\mathrm{OH}$ production is relatively slow, $\mathrm{OH}$ increases in response to reductions in $\mathrm{CO}$ transported from lower latitudes and in polar methane concentrations (Table 3). The increase is greatest in LGM summer over regions with enhanced snow and ice cover (e.g., the Southern Ocean and the Laurentide Ice Sheet) and thus higher UV surface albedos relative to the preindustrial or present day. The polar changes are inconsequential for global $\mathrm{OH}$, but are of potential interest for the interpretation of measurements of trace gases from ice cores.

\subsection{Tropospheric ozone}

The tropospheric ozone burden decreases in each progressively colder scenario (Fig. 8). Relative to the preindustrial, present-day ozone increases $+28 \pm 11 \%(+35 \%$ best estimate), somewhat less than the mean change of $+41 \pm 9 \%$ from 1850 to 2000 in the ACCMIP ensemble (Young et al., 2013 ) or the $+40-48 \%$ changes simulated by changing emissions in GEOS-Chem by Sofen et al. (2011) and Parrella et al. (2012). Our more tempered response likely reflects the relatively high cross-tropopause flux of ozone in our model, and in the case of Sofen et al. (2011) and Parrella et al. (2012), our much higher fire emissions in the preindustrial. Our simulated changes of $-20 \pm 9 \%(-20 \%$ best 


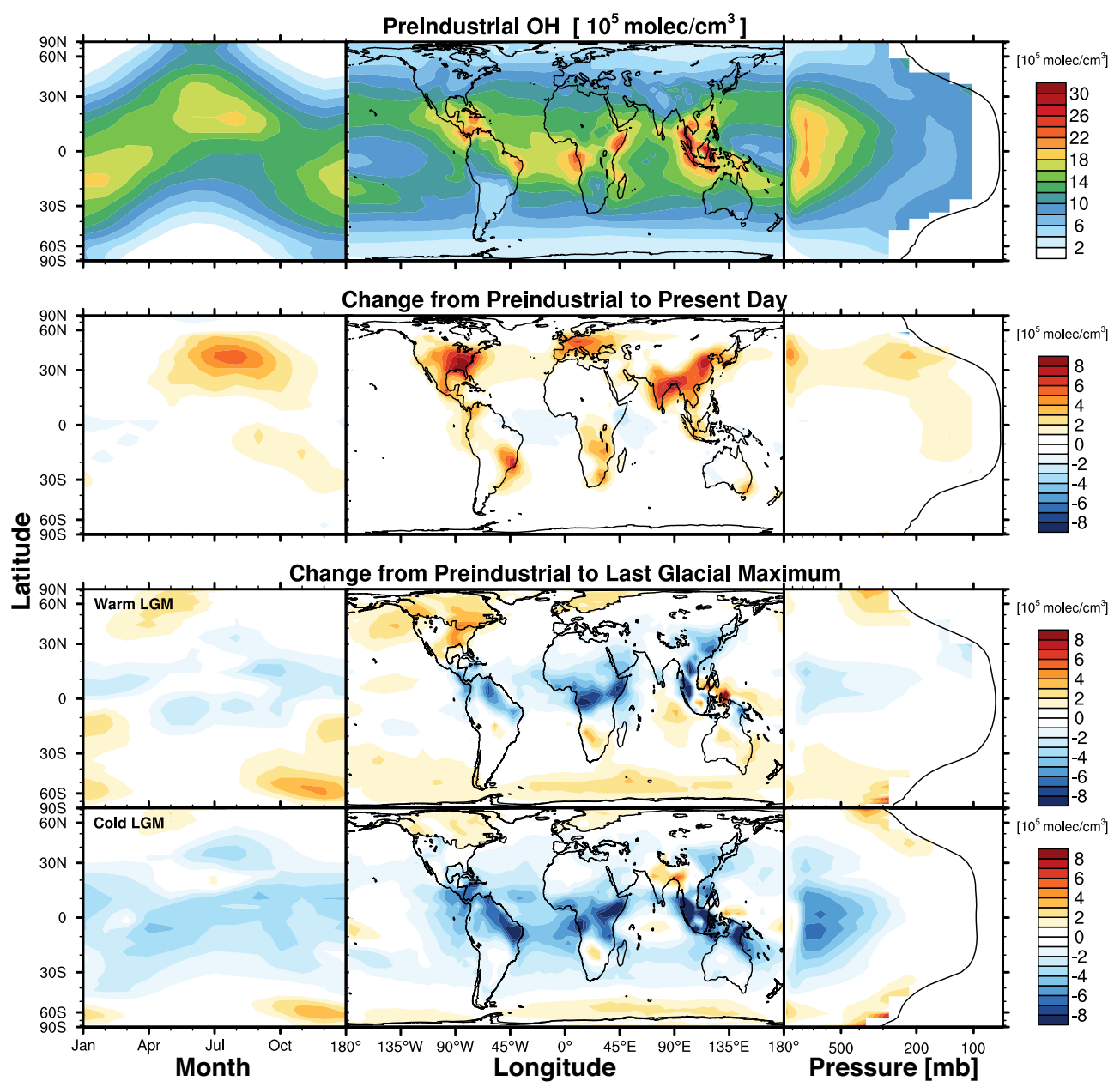

Fig. 12. Spatiotemporal distribution of $\mathrm{OH}$ concentrations $\left(10^{5} \mathrm{molec} \mathrm{cm}^{-3}\right)$ in the preindustrial simulation (top row), and absolute changes in the present day (second row) and LGM (third and fourth rows) relative to the preindustrial. Each row contains three plots sharing a common ordinate axis (area-weighted latitude) and presents mass-weighted tropospheric $\mathrm{OH}$ concentrations averaged across different dimensions. From left to right, a Hovmöller plot shows seasonality in zonal mean column densities, a map shows the horizontal distribution of the tropospheric mean columns, and an altitude plot shows the zonal mean vertical distribution. Mean tropopause pressure is shown as the black line in the rightmost column. All difference plots share a common color bar.

estimate) in the LGM tropospheric ozone burden relative to the preindustrial are consistent with previous estimates (Table 1).

To understand these changes, we examine the ozone budget in each simulation (Fig. 13). Photochemical production increases in the present day, relative to the preindustrial, but decreases in the two LGM scenarios in response to reductions in photolysis rates and in emissions of $\mathrm{NO}_{\mathrm{x}}, \mathrm{CO}$, and VOCs. Ozone production efficiencies (OPE) per molecule $\mathrm{NO}_{\mathrm{x}}$ emitted (Liu et al., 1987), as shown in the middle panel of Fig. 13, have decreased in the present day by 15 to $37 \%$, and range from $30 \%$ decreases to $45 \%$ increases in the LGM relative to the preindustrial, although changes from the LGM are small within each of the three emission scenarios.

The cross-tropopause ozone flux decreases in each colder climate in response to the deceleration of the stratospheric circulation (Sect. 3.2) together with decreases in extratropical lower-stratospheric ozone (Sect. 5.1 and Fig. 11) where most stratosphere-to-troposphere transport occurs. Nonetheless, transport of ozone from the stratosphere becomes an increasingly important fraction of total ozone sources in each colder climate, increasing from $17 \%$ in the present day to $33 \%$ in the cold-LGM scenario.

The bottom panel of Fig. 13 gives the lifetime of tropospheric ozone in each simulation. Loss is primarily by photolysis in the presence of water vapor (i.e., primary production of $\mathrm{OH}$ ), but also by reaction with $\mathrm{HO}_{\mathrm{x}}$ radicals; both decrease in each cold climate as described in Sect. 5.1 and Sect. 5.3. The lifetime of the present-day simulation driven by ModelE (23d) is comparable to that of the multi-model ensemble of Stevenson et al. (2006) (22 $\pm 2 \mathrm{~d})$. 

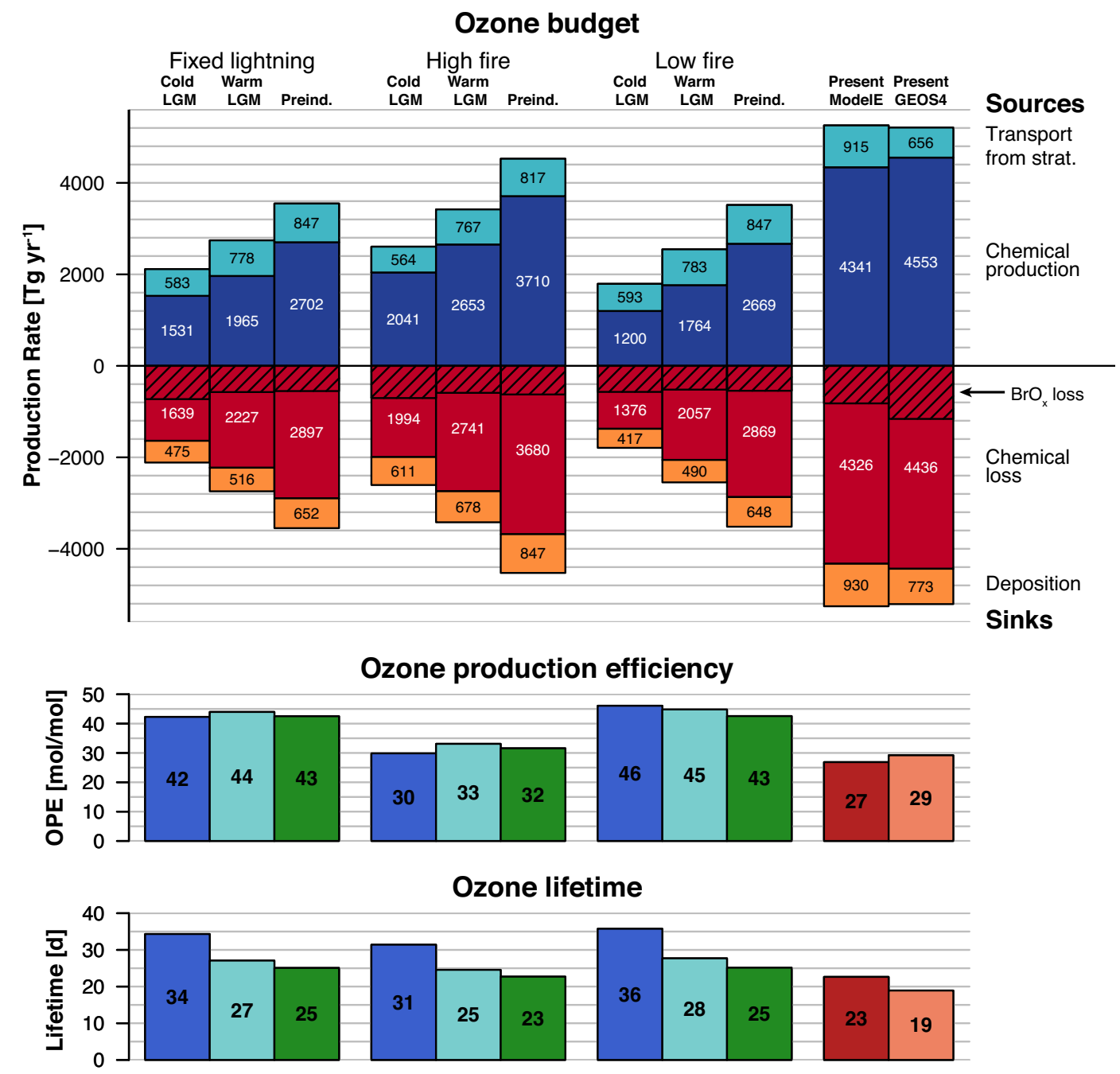

Fig. 13. Top panel: budget of tropospheric ozone in each simulation. Production and loss rates are for the odd oxygen family $\left(\mathrm{O}_{\mathrm{x}} \equiv \mathrm{O}_{3}+\right.$ $\mathrm{O}+\mathrm{NO}_{2}+2 \mathrm{NO}_{3}+$ organic nitrates $\left.+\mathrm{HNO}_{4}+3 \mathrm{~N}_{2} \mathrm{O}_{5}+\mathrm{HNO}_{3}+\mathrm{BrO}+\mathrm{HOBr}+\mathrm{BrNO}_{2}+2 \mathrm{BrNO}_{3}\right)$. Transport from the stratosphere is inferred by mass balance in the troposphere with chemical production, loss, and deposition. Tropopause calculated with thermal lapse rate definition. Diagonal hatching indicates net magnitude of ozone destroyed by $\mathrm{BrO}+h v \rightarrow \mathrm{O}_{3}+\mathrm{Br}$ and $\mathrm{Br}+\mathrm{O}_{3} \rightarrow \mathrm{BrO}+\mathrm{O}_{2}$. Middle panel: $\mathrm{O}_{\mathrm{x}}$ production efficiency per unit $\mathrm{NO}_{\mathrm{x}}$ emitted. Bottom panel: lifetime of tropospheric ozone against chemical loss and deposition.

Bromine represents an increasingly important component ( 16 to $34 \%$ ) of the total loss rates in each successively colder climate, as the net loss of ozone from the cycling of $\mathrm{BrO}_{\mathrm{x}}$ radicals (shown as hatching in the top panel of Fig. 13) remains relatively constant between simulations. This reflects the nearly constant emissions of $\mathrm{Br}_{\mathrm{y}}$. The depositional loss frequencies decrease in each successively colder climate scenario, reflecting decreases in LAI and total vegetated area (despite the exposed continental margins) and, to a lesser extent, decreases in surface friction velocities.

The multi-model comparisons by Stevenson et al. (2006) and Young et al. (2013) show a tight linear relationship between ozone burdens and $\mathrm{NO}_{\mathrm{x}}$ emissions. Our simulations extend the relationship of the tropospheric ozone burden with $\mathrm{NO}_{\mathrm{x}}$ into the different climate and emission scenarios of the
LGM, with an almost identical slope to Young et al. (2013). In the 10 simulations driven by ModelE meteorology, $94 \%$ of the variability in the tropospheric ozone burden, $X_{\mathrm{O}_{3}}$, is explained by differences in $\mathrm{NO}_{\mathrm{x}}$ emissions alone $\left(X_{\mathrm{O}_{3}}=\right.$ $[160 \mathrm{Tg}]+\left[52 \mathrm{Tg} \mathrm{Tmol}^{-1}\right.$ year $\left.] S_{\mathrm{N}}\right)$, likely reflecting that the majority of the atmosphere is $\mathrm{NO}_{\mathrm{x}}$-limited (Sillman et al., 1990). However, ozone is also strongly correlated with $S_{\mathrm{C}}$ $\left(X_{\mathrm{O}_{3}}=[150 \mathrm{Tg}]+\left[1.4 \mathrm{Tg} \mathrm{Tmol}^{-1}\right.\right.$ year $\left.] S_{\mathrm{C}} ; R^{2}=0.86\right)$.

Figure 14 shows the changes in the temporal and spatial distribution of ozone relative to the preindustrial in our low-fire simulations, which have similar patterns to the other emissions scenarios. In the preindustrial simulations, tropospheric ozone columns peak at the poles during their respective spring months due to transport from the stratosphere, consistent with Mickley et al. (2001). In the present day, 
ozone increases everywhere due to anthropogenic precursor emissions, particularly in the temperate latitudes of the Northern Hemisphere. Extratropical ozone also increases in both hemispheres because of enhanced transport from the stratosphere, especially at the poles. Most of the LGM troposphere has reduced ozone relative to the preindustrial driven by the changes in climate and emissions. Greenland experiences local enhancements in stratospheric downwelling at the LGM, probably driven by the presence of the Laurentide and Fennoscandian ice sheets.

Despite inclusion of bromine chemistry, our simulated reduction in global ozone at the preindustrial is not sufficient to explain the low concentrations derived from surface air measurements taken in the late 19th century (e.g., Pavelin et al., 1999). Reproduction of these low values remains a long-standing issue in the modeling of past changes in tropospheric ozone (Wang and Jacob, 1998; Mickley et al., 2001; Shindell et al., 2003; Lamarque et al., 2005; Horowitz, 2006; Parrella et al., 2012; Young et al., 2013).

\subsection{Hydrogen peroxide}

$\mathrm{H}_{2} \mathrm{O}_{2}$ responds sensitively to different climates and emission scenarios (Fig. 8), changing by $+18 \pm 22 \%$ in the present day and by $-36 \pm 21 \%$ at the LGM relative to the preindustrial ( +31 and $-23 \%$ best estimate). Its tropospheric budget is given in Table $6 . \mathrm{H}_{2} \mathrm{O}_{2}$ is both a reservoir species for $\mathrm{HO}_{\mathrm{x}}$ and the dominant $\mathrm{HO}_{\mathrm{x}}$ sink. The main loss mechanism for $\mathrm{H}_{2} \mathrm{O}_{2}$, and thus $\mathrm{HO}_{\mathrm{x}}$, is via uptake by cloud droplets and subsequent deposition. Despite reductions in precipitation in each successively colder climate that increase the $\mathrm{H}_{2} \mathrm{O}_{2}$ lifetime against deposition, we find that the decline in $\mathrm{HO}_{\mathrm{x}}$ production in the colder climates (Sect. 5.1) governs the changes in $\mathrm{H}_{2} \mathrm{O}_{2}$. Our simulations indicate that $\mathrm{H}_{2} \mathrm{O}_{2}$, unlike $\mathrm{OH}$, is very sensitive to changing fire emissions, with $\mathrm{H}_{2} \mathrm{O}_{2}$ levels in the high-fire scenarios $40-70 \%$ greater than in the lowfire scenarios. Fire emissions generate peroxy radicals $\left(\mathrm{RO}_{2}\right)$ and therefore can enhance total $\mathrm{HO}_{\mathrm{x}}$ (although not $\mathrm{OH}$, for reasons described in Sect. 5.1). The sensitivity of $\mathrm{H}_{2} \mathrm{O}_{2}$ to fire emissions but not to lightning make ice-core measurements of this molecule a potentially useful proxy for paleo fire abundance. $\mathrm{H}_{2} \mathrm{O}_{2}$ could also reflect changes in biogenic VOC emissions, as they also generate $\mathrm{RO}_{2}$.

Figure 15 shows the spatiotemporal distribution of $\mathrm{H}_{2} \mathrm{O}_{2}$ and its changes in our low-fire simulations. Production of $\mathrm{H}_{2} \mathrm{O}_{2}$ is greatest in the tropics, coincident with maximum production of $\mathrm{OH}$ and therefore $\mathrm{HO}_{\mathrm{x}}$. However, the solubility of $\mathrm{H}_{2} \mathrm{O}_{2}$ causes high loss in the intertropical convergence zone, leading to the maxima in $\mathrm{H}_{2} \mathrm{O}_{2}$ concentrations in the subtropical lower free troposphere. At the LGM, precipitation increases in the subtropics and decreases in the tropics relative to the preindustrial in our simulations (Fig. 3), but these changes are not enough to offset reductions in primary production, and $\mathrm{H}_{2} \mathrm{O}_{2}$ decreases almost everywhere. The exception is over Southeast Asia in the warm LGM, where en- hanced reactive carbon emissions from biogenics and fires over the exposed continental shelves (Fig. 7) promote $\mathrm{RO}_{2}$ production. In the present day relative to the low-fire preindustrial scenario, $\mathrm{H}_{2} \mathrm{O}_{2}$ increases everywhere.

The overall decrease in $\mathrm{H}_{2} \mathrm{O}_{2}$ levels has implications for the oxidation pathways of $\mathrm{SO}_{2}$, which is primarily oxidized to sulfate in the aqueous phase by $\mathrm{H}_{2} \mathrm{O}_{2}$ within cloud droplets. If a greater fraction of $\mathrm{SO}_{2}$ is instead oxidized by $\mathrm{OH}$ in the gas phase, it would lead to additional particle formation with associated direct and indirect climate effects.

\subsection{Nitrate radical}

The chemistry of the nighttime troposphere is dominated by the gas-phase nitrate radical $\mathrm{NO}_{3}$, acting as the major dark oxidant for VOCs that would otherwise react during daytime to form ozone (Wayne et al., 1991). In the absence of solar radiation, almost all $\mathrm{NO}_{\mathrm{x}}$ is converted to $\mathrm{NO}_{2}$, which may react with ozone to produce $\mathrm{NO}_{3}$. The tropospheric burden changes by $+130 \pm 70 \%$ at the present day and $-46 \pm 26 \%$ at the LGM, relative to the preindustrial $(+180$ and $-48 \%$ best estimate). The tropospheric burden of $\mathrm{NO}_{3}\left(X_{\mathrm{NO}_{3}}\right)$ in each of the 11 simulations shown in the bottom-right panel of Fig. 8 almost exactly follows the total source of reactive nitrogen $\left(X_{\mathrm{NO}_{3}}=0.014\right.$ pptv Tg N ${ }^{-1}$ year $\left.\times S_{\mathrm{N}} ; R^{2}=0.97\right)$. How $\mathrm{NO}_{3}$ changes in different climates is therefore sensitive to assumptions made about lightning, fire, and soil emissions.

\section{Comparison with ice-core record}

Observations of reactive species in ice cores are limited for the preindustrial, and even more so for the LGM (Wolff, 2012), but offer our only constraints for the chemical composition of past atmospheres. Comparison of our model simulations with the ice-core record is important for both evaluation of the model and for interpretation of the observations, particularly for placing polar observations in the context of the entire troposphere. However, many reactive species are suspected or known to undergo post-depositional changes (e.g., Hutterli et al., 2002, 2003; Haan et al., 1996), which complicates interpretation.

Formaldehyde (HCHO) undergoes substantial postdepositional processing via evaporation followed by photolysis. The degree of post-depositional processing is strongly influenced by local temperature and the snow accumulation rate (Hutterli et al., 2002, 2003). The available HCHO data have not been corrected since that realization, though our simulations qualitatively match measurements from Greenland (Staffelbach et al., 1991) and Antarctica (Gillett et al., 2000). Our results indicate that $\mathrm{HCHO}$ was relatively stable through the past 1000 years and then increased in the 20th century following increases in VOC precursors $(70 \%$ simulated vs. $100 \%$ observed increases at Greenland; $+40 \%$ vs. $+40-100 \%$ for Antarctica). At the LGM, however, the 


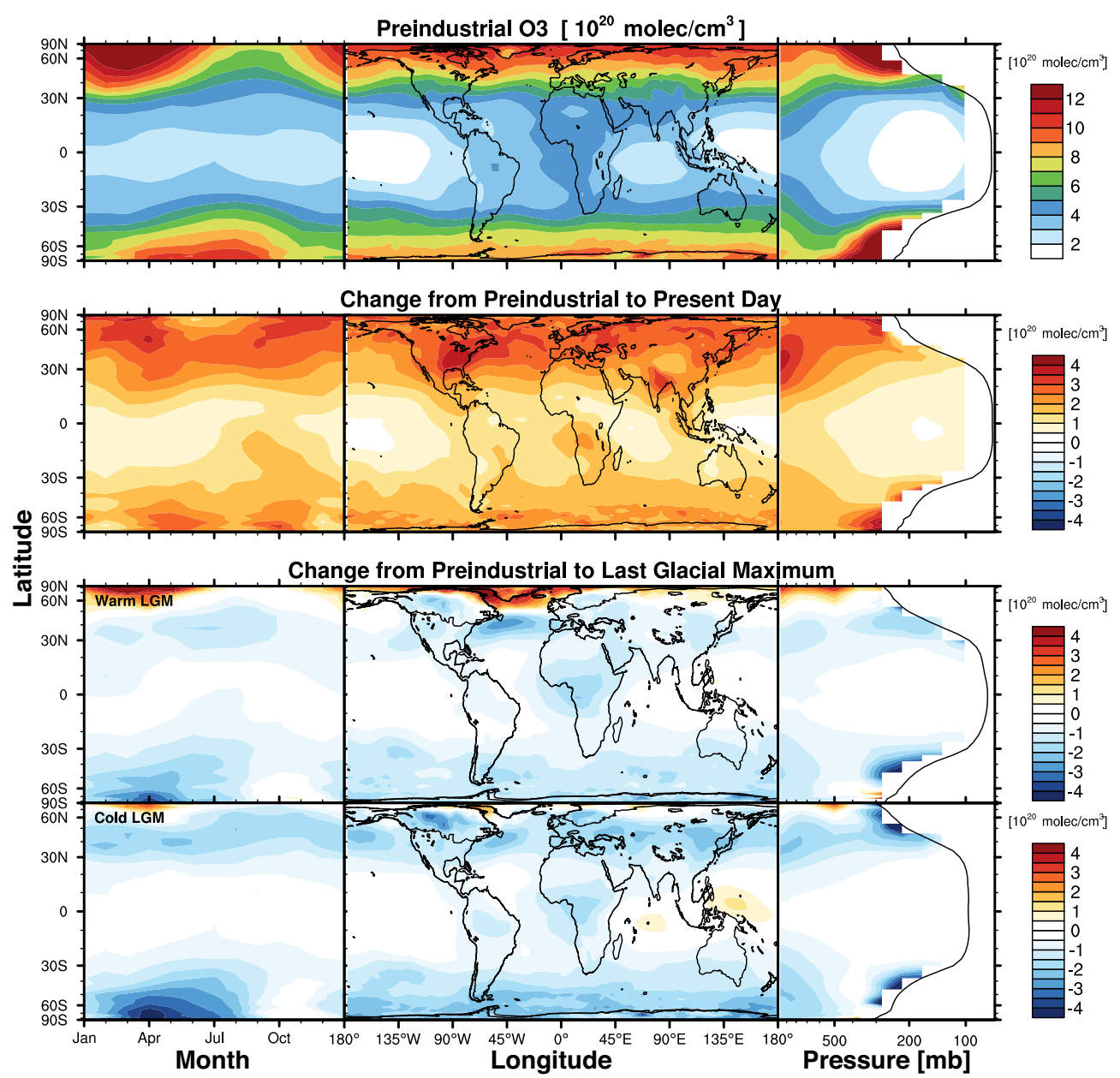

Fig. 14. Same as Fig. 12 but for tropospheric ozone concentrations $\left(10^{20} \mathrm{molec}^{-3}\right)$.

Antarctic ice core indicates a $100 \%$ increase relative to the preindustrial, while we simulate $27-36 \%$ decreases in surface concentrations. This discrepancy may be due to the temperature dependence of $\mathrm{HCHO}$ preservation in ice cores, with increased $\mathrm{HCHO}$ preservation in the very cold temperatures of the LGM (Hutterli et al., 2003).

The ratio of $\mathrm{HCHO}$ to methane in ice cores has been identified as a potential proxy for polar $\mathrm{OH}$ abundance, as production of $\mathrm{HCHO}$ in the remote atmosphere results primarily from methane oxidation (Staffelbach et al., 1991). Given the large uncertainty in ice-core HCHO (Hutterli et al., 2002, 2003), it is unclear what to make of uncorrected $\mathrm{HCHO} /$ methane ratios. Our simulations, like those of Levine et al. (2011a), show that this ratio at most offers local information, and that only in the polar regions, where methane is the dominant source of HCHO. Tropospheric mean $\mathrm{OH}$ (weighted by the methane reaction rate constant) is strongly correlated with tropospheric mean ratio of $\mathrm{HCHO} /$ methane in the preindustrial and present-day simulations ( $R^{2}=0.82 ; n=5$ simulations) but uncorrelated in the LGM scenarios. The erosion of the correlation between tropospheric mean $\mathrm{OH}$ and $\mathrm{HCHO} /$ methane over glacialinterglacial timescales may reflect variability in NMVOC precursors to $\mathrm{HCHO}$, stronger sensitivity of the $\mathrm{CH}_{4}+\mathrm{OH}$ reaction to temperature relative to other NMVOCs, changes in the meridional distribution of methane, and/or changes in photolysis loss frequencies of $\mathrm{HCHO}$.

$\mathrm{H}_{2} \mathrm{O}_{2}$ is the only oxidant directly preserved in ice cores, but like $\mathrm{HCHO}$ it undergoes post-depositional processing that should be considered (Hutterli et al., 2003). Ice cores from the West Antarctic Ice Sheet (WAIS) considered representative of surface air concentrations indicate $\mathrm{H}_{2} \mathrm{O}_{2}$ was relatively constant over the past 500 years but has at least doubled since 1950 (Frey et al., 2006); uncorrected data from Greenland cores also show a large 20th-century increase (Fuhrer et al., 1993; Anklin and Bales, 1997). Compared to our preindustrial low-fire scenario, deposition of $\mathrm{H}_{2} \mathrm{O}_{2}$ increases by $31 \%$ over Greenland in the present day, consistent with the ice-core record. However, over the WAIS, surface concentrations increase by only $5 \%$ and deposition shows no significant change due to decreases in precipitation in our model here. In their simulations, Lamarque et al. 


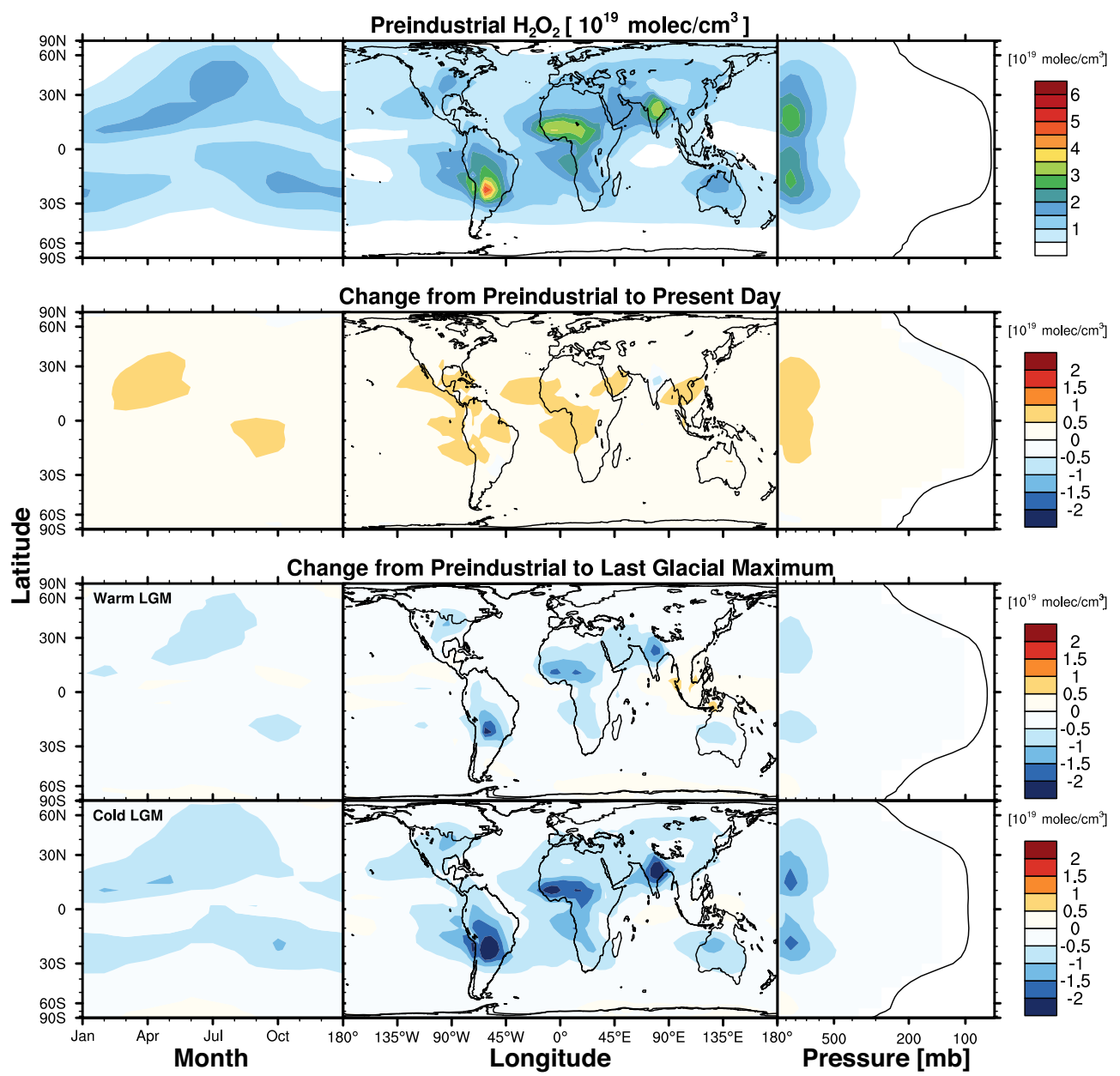

Fig. 15. Same as Fig. 12 but for $\mathrm{H}_{2} \mathrm{O}_{2}\left(10^{19}\right.$ molec $\left.\mathrm{cm}^{-3}\right)$.

Table 6. Global sources, sinks, and lifetimes for tropospheric $\mathrm{H}_{2} \mathrm{O}_{2}$

\begin{tabular}{|c|c|c|c|c|c|c|c|c|c|c|c|}
\hline \multirow{3}{*}{$\begin{array}{l}\text { Emissions } \\
\text { Climate }\end{array}$} & \multicolumn{3}{|c|}{ Fixed lightning } & \multicolumn{3}{|c|}{ High fire } & \multicolumn{3}{|c|}{ Low fire } & & \\
\hline & \multicolumn{2}{|c|}{ LGM } & \multirow{2}{*}{ Preind. } & \multicolumn{2}{|c|}{ LGM } & \multirow{2}{*}{ Preind. } & \multicolumn{2}{|c|}{ LGM } & \multirow{2}{*}{ Preind. } & \multicolumn{2}{|c|}{ Present } \\
\hline & Cold & Warm & & Cold & Warm & & Cold & Warm & & ModelE & GEOS4 \\
\hline Burden (Tmol) & 0.03 & 0.05 & 0.08 & 0.06 & 0.08 & 0.11 & 0.04 & 0.06 & 0.08 & 0.10 & 0.12 \\
\hline Sources $\left(\right.$ Tmol year $\left.^{-1}\right)$ & & & & & & & & & & & \\
\hline Chemical production & 10 & 16 & 23 & 16 & 24 & 33 & 10 & 17 & 23 & 32 & 33 \\
\hline Sinks $\left(\right.$ Tmol year $\left.{ }^{-1}\right)$ & & & & & & & & & & & \\
\hline Chemical loss & 6 & 10 & 14 & 9 & 14 & 19 & 6 & 10 & 14 & 19 & 22 \\
\hline Dry deposition & 1 & 1 & 2 & 2 & 2 & 3 & 1 & 2 & 2 & 3 & 4 \\
\hline Wet deposition & 3 & 5 & 8 & 5 & 7 & 11 & 3 & 5 & 8 & 10 & 7 \\
\hline Lifetime (h) & 30 & 28 & 29 & 33 & 30 & 29 & 33 & 30 & 29 & 28 & 32 \\
\hline
\end{tabular}

(2011) attribute the late-20th century increase in the WAIS record to the ozone hole, whose heterogeneous chemistry we do not simulate here. The preindustrial high-fire simulation is inconsistent with the ice-core data, as it implies lower $\mathrm{H}_{2} \mathrm{O}_{2}$ surface concentrations and deposition everywhere in the present day relative to the preindustrial. For the LGM, uncor- rected measurements from Law Dome in East Antarctica imply decreases in $\mathrm{H}_{2} \mathrm{O}_{2}$ relative to the preindustrial (vanOmmen and Morgan, 1996), generally matched by reduced deposition fluxes in our simulations despite enhanced surface concentrations. Surface concentrations over East Antarctica generally increase relative to the preindustrial in our various 
LGM simulations because of enhanced polar $\mathrm{OH}$ production (Sect. 5.1) and decreased precipitation (Sect. 3.2), with large variability reflecting the wide spread in the LGM fire emissions as $\mathrm{HO}_{\mathrm{x}}$ precursors.

Our present-day simulation matches the mean CO surface concentration of 49 ppbv measured at the South Pole by the NOAA Global Monitoring Division for the 1990s, as well as the southern hemispheric gradient in CO. Carbon monoxide has been recorded in ice-core air bubbles over the past two millennia. Wang et al. (2010) measured ice-core concentrations of CO at the South Pole of $47 \pm 4$ ppbv for 1770. Our low-fire preindustrial scenario yields $35 \mathrm{ppbv}$ surface $\mathrm{CO}$ at the South Pole, consistent with Wang et al. (2010), given that as much as $10 \mathrm{ppbv}$ of $\mathrm{CO}$ in Antarctic ice cores may derive from in situ production (Haan and Raynaud, 1998). Our highfire simulations yield much higher surface concentrations of $63 \mathrm{ppbv}$ at the preindustrial, a value that is greater than any over the entire $\mathrm{CO}$ ice-core record for Antarctica.

Black carbon deposited in Greenland ice cores increased from 1850 to 1950 due to human industrial activity, but then declined to the 1800 values by the late 1950s (McConnell et al., 2007). Records of black carbon deposition to Antarctica for 1850-2000 imply mostly constant deposition rates (Bisiaux et al., 2012). Squaring these records of black carbon deposition with our model results is challenging. Our highfire scenario for the preindustrial implies $40-50 \%$ decreases in black carbon deposition to both Greenland and Antarctica from the 1770 s to the present day, not consistent with observations. Our low-fire preindustrial scenario yields a better match with the observations over Antarctica, with similar rates of deposition in the 1770s and the present day. But this same scenario indicates large, 40-500\%, increases in black carbon deposited to Greenland in the present day relative to the 1770s. Reconciling both the black carbon and CO icecore records with current understanding of trends in biomass burning is a direction for future research.

Antarctic ice cores show increased sea salt aerosol deposition during cold periods, perhaps as a result of enhanced sea salt emission from frost flowers across the greater expanse of sea ice (Wolff, 2003; Wolff et al., 2006; Fischer et al., 2007; Rothlisberger et al., 2008; Röthlisberger et al., 2010; Wolff et al., 2010). GEOS-Chem assumes no source of sea salt from sea ice (Fig. 6e; Jaeglé et al., 2011), and therefore predicts $70-90 \%$ decreases in sea salt deposition to Antarctica in the LGM climate relative to the preindustrial.

The $\Delta^{17} \mathrm{O}$ of ice-core sulfate measures the departure from mass-dependent fractionation in its oxygen isotopes (Thiemens, 2006). It provides a constraint for assessing the relative importance of different sulfate chemical production pathways, i.e., gas-phase oxidation by $\mathrm{OH}$ vs. aqueous-phase production via $\mathrm{H}_{2} \mathrm{O}_{2}$ or ozone, as the latter imparts a large $\Delta{ }^{17} \mathrm{O}$ signature (Savarino et al., 2000). Measurements from the Vostok ice core in Antarctica imply that gas-phase oxidation by $\mathrm{OH}$ contributed up to $40 \%$ more to sulfate production during the LGM relative to the interglacial periods that came before or after (Alexander et al., 2002).

Our results appear consistent with these measurements of $\Delta^{17} \mathrm{O}$ of sulfate. In our LGM scenarios, surface concentrations of $\mathrm{OH}$ at the poles increase, driven primarily by the reduction in methane, $\mathrm{CO}$, and overhead ozone, as well as increases in surface $\mathrm{UV}$ albedo. In addition, the fraction of $\mathrm{SO}_{2}$ oxidized in the gas phase by $\mathrm{OH}$ increases throughout the LGM troposphere, reflecting a global decrease in aqueousphase chemistry in the drier climate.

Unlike sulfate, nitrate aerosol undergoes substantial postdepositional photochemical processing via evaporation of $\mathrm{HNO}_{3}$ (Rothlisberger et al., 2002) and photolysis to produce $\mathrm{NO}_{\mathrm{x}}$ (Honrath et al., 1999, 2000). Photolysis of snow nitrate to produce $\mathrm{NO}_{\mathrm{x}}$ is thought to be dominant (Davis et al., 2008; Erbland et al., 2012). The degree of post-depositional processing depends mainly on snow accumulation rate. In East Antarctica, where the snow accumulation rate is low, it is thought that all of the nitrate originally deposited to the snow is photolyzed to $\mathrm{NO}_{\mathrm{x}}$ during austral spring and summer (Erbland et al., 2012). This $\mathrm{NO}_{\mathrm{x}}$ is released to the boundary layer, where it is re-oxidized locally and redeposited to the snow surface as nitrate. The $\Delta^{17} \mathrm{O}$ signature in East Antarctic ice-core nitrate thus reflects the relative abundance of local atmospheric oxidants ozone and $\mathrm{RO}_{2}$. At locations with higher snow accumulation rates such as Greenland and West Antarctica, the $\Delta^{17} \mathrm{O}$ of nitrate may reflect a combination of the local summertime ozone $/ \mathrm{RO}_{2}$ ratio and that ratio in the $\mathrm{NO}_{\mathrm{x}}$ source regions.

For the present day, our low-fire simulations yield a $4 \%$ increase in the ozone $/ \mathrm{RO}_{2}$ ratio over Greenland and a $7 \%$ decrease over the WAIS, qualitatively consistent with the expected sign changes from ice-core measurements of $\Delta^{17} \mathrm{O}$ of nitrate (Alexander et al., 2004; Sofen et al., 2014). For the LGM, we calculate $20-40 \%$ increases in the ozone $/ \mathrm{RO}_{2}$ ratio over East Antarctica relative to the preindustrial, and up to a $50 \%$ increase over Greenland. Over Greenland, the increases result from increases in both tropospheric ozone from local enhanced stratospheric downwelling (Fig. 14) and reductions in $\mathrm{RO}_{2}$. Over Antarctica, ozone decreases in both LGM scenarios, so decreases in $\mathrm{RO}_{2}$ largely dominate the response. Observations of nitrate $\Delta^{17} \mathrm{O}$ in the LGM are not yet published, but are currently being collected.

\section{Implications for the methane budget}

Table 7 gives the global methane lifetime against $\mathrm{OH}$ oxidation in the troposphere $\left(\tau_{\mathrm{CH}_{4}, \mathrm{OH}}\right)$ for each simulation, which largely determines the removal efficiency of methane from the atmosphere. We find $\tau_{\mathrm{CH}_{4}, \mathrm{OH}}$ in our present-day simulations decreases by $7 \pm 3 \%$ relative to the preindustrial. In the warm-LGM scenario, $\tau_{\mathrm{CH}_{4} \text {, } \mathrm{OH}}$ changes little from the preindustrial $(0.2 \pm 6 \%)$, but increases by $35 \pm 16 \%$ in the coldLGM scenario. In our most likely representation of change 
across the glacial-interglacial period, with low fire and warm LGM, $\tau_{\mathrm{CH}_{4}, \mathrm{OH}}$ is $4.5 \%$ higher at the LGM than in the preindustrial. We diagnose these changes below.

The value of $\tau_{\mathrm{CH}_{4}, \mathrm{OH}}$ is given by the global burden ( $\mathrm{Tg}$ ) divided by the total loss rate in the troposphere $\left(\mathrm{Tg} \mathrm{year}^{-1}\right)$, i.e.,

$$
\tau_{\mathrm{CH}_{4}, \mathrm{OH}}=\frac{\int_{\text {surface }}^{\mathrm{TOA}}\left[\mathrm{CH}_{4}\right] d x d y d p}{\int_{\text {surface }}^{\text {tropopause }} k_{\mathrm{CH}_{4}+\mathrm{OH}}(T)[\mathrm{OH}]\left[\mathrm{CH}_{4}\right] d x d y d p} .
$$

It therefore responds to convolved changes in the tropospheric $\mathrm{OH}$ and methane distributions and the strong temperature kinetic effect $\left(2.4 \% \mathrm{~K}^{-1}\right.$ at $\left.273 \mathrm{~K}\right)$ on the reaction rate constant, $k_{\mathrm{CH}_{4}+\mathrm{OH}}$ (Lawrence et al., 2001; Sander et al., 2011; John et al., 2012). The temperature changes alone cause $\tau_{\mathrm{CH}_{4}, \mathrm{OH}}$ to increase by $4.2 \%$ in the warm-LGM scenario and $20 \%$ in the cold-LGM relative to the preindustrial, and decrease by $1.4 \%$ at the present day. At the LGM, this effect is partially countered by the shift of the methane maximum from the northern high latitudes to the tropics, which by itself leads to a $1.9 \%$ decrease in $\tau_{\mathrm{CH}_{4}, \mathrm{OH}}$. Changes in the methane meridional distribution are negligible from the preindustrial to present, despite the large change in the mean concentration. The kinetic temperature and methane distribution effects are then offset or enhanced by changes in $\mathrm{OH}$ responding to the factors outlined in Sect. 5.1. In the present day, the kinetic effect is augmented by the increase in tropospheric mean $\mathrm{OH}$, and the lifetime decreases relative to the preindustrial. In the warm-LGM scenario, the net effect of the changes in temperature and methane distribution is small, and therefore changes in $\mathrm{OH}$ dominate $\tau_{\mathrm{CH}_{4}}$, OH. In the coldLGM scenario, the temperature kinetic effect guarantees that $\tau_{\mathrm{CH}_{4}, \mathrm{OH}}$ increases relative to the preindustrial.

That $\tau_{\mathrm{CH}_{4}, \mathrm{OH}}$ remains nearly constant or increases at the LGM in our simulations puts a higher burden on sources in explaining the glacial-interglacial variability of atmospheric methane concentrations recorded in ice cores. In their model study, which did not include a paleo-stratosphere, Levine et al. (2011c) concluded that the effects of temperature and biogenic VOCs cancel each other out such that observed changes in ice-core methane must be driven primarily by sources. Our findings confirm those of Levine et al. (2011c), and extend them to include changes in overhead ozone and $\mathrm{NO}_{\mathrm{x}}$, which together may even drive decreased $\mathrm{OH}$ at the LGM relative to the preindustrial.

Assuming no large changes occurred in the minor loss mechanisms for methane (soils and stratospheric OH; IPCC, 2007), the source of methane emissions scales as its loss by $\mathrm{OH}$ in the troposphere (Table 7 and Fig. 9). We estimate that the methane loss frequency in the stratosphere changes less than $1 \%$ since the LGM in our simulations; the effect of reduced stratospheric water vapor at the LGM is largely offset by temperature increases. Our results imply that relative to the preindustrial, total methane emissions are $150 \%$ higher in the present, and are reduced by $42-65 \%$ at the LGM, with a $50 \%$ reduction our best estimate. These estimated reductions at the LGM are greater than the 29-42\% decrease in wetland emissions simulated by the PMIP2 ensemble members (Weber et al., 2010), and much larger than the 16 and $23 \%$ decreases in natural methane emissions simulated by Kaplan et al. (2006) and Valdes et al. (2005) over the same period. However, we note that if the tropical fraction of total methane in LGM were to increase by $33 \%$ as implied by a Bolivian ice core (Campen, 2000) - an extremely unlikely scenario (Sect. 2.4) - the implied methane source would in fact be consistent with the previous bottom-up estimates, as the integrated loss rate of methane (denominator of Eq. 2) would increase despite the reductions in $\mathrm{OH}$ and temperature.

\section{Discussion and conclusions}

We present a stepwise, offline-coupled modeling framework for simulating paleo-oxidant levels since the LGM. Our goal is to test within a 3-D model framework the sensitivity of tropospheric oxidants over a range of likely forcings from climate-driven and anthropogenic changes. Archived meteorology from the GISS ModelE GCM is used to drive the BIOME4-TG global equilibrium terrestrial vegetation model and the LPJ-LMfire fire model. We also apply the ModelE meteorology to the GEOS-Chem CTM, together with the BIOME4-TG vegetation structure and LPJ-LMfire emissions. We then perform detailed simulations of tropospheric composition with an online-coupled linearized stratospheric chemistry scheme. Offline coupling allows for rapid sensitivity tests and identification of first-order effects of changing climate on composition. However, it does not enable the examination of chemical feedbacks on climate, which would require a fully integrated Earth system model, such as ModelE2 (Shindell et al., 2013).

We simulate four different time slices with the GCM: the present day (ca. 1990s); preindustrial (ca. 1770s); and two possible realizations of the Last Glacial Maximum (LGM; $21 \mathrm{ka}$ ), one significantly colder than the other, reflecting uncertainty in the extent of tropical cooling at the LGM. The climate simulations are forced by prescribing greenhouse gas levels, orbital parameters, SSTs, sea ice extent, and ice sheet topography. Reductions in greenhouse gases drive decreases in tropospheric temperatures and water vapor, and decelerate the stratospheric residual circulation, consistent with earlier work (Braconnot et al., 2007a; Bartlein et al., 2011; Rind et al., 2009). Relative to preindustrial, tropical surface air temperatures are $1.4^{\circ} \mathrm{C}$ colder in the warm-LGM scenario and $6.8^{\circ} \mathrm{C}$ colder in the cold-LGM scenario; the preindustrial to present-day change is $+0.5^{\circ} \mathrm{C}$. Reduced stratospheric circulation leads to an increase in tropical stratospheric ozone columns, which strongly affect tropospheric photolysis rates. 
Table 7. Global methane burden and lifetime against tropospheric oxidation by $\mathrm{OH}\left(\tau_{\mathrm{CH}_{4}, \mathrm{OH}}\right)$.

\begin{tabular}{|c|c|c|c|c|c|c|c|c|c|c|c|c|}
\hline \multirow{2}{*}{$\begin{array}{l}\text { Emission Scenario } \\
\text { Climate }\end{array}$} & \multicolumn{3}{|c|}{ Fixed lightning } & \multicolumn{3}{|c|}{ High fire } & \multicolumn{3}{|c|}{ Low fire } & \multicolumn{3}{|c|}{ Present day } \\
\hline & $\begin{array}{l}\text { Cold } \\
\text { LGM }\end{array}$ & $\begin{array}{l}\text { Warm } \\
\text { LGM }\end{array}$ & Preind. & $\begin{array}{c}\text { Cold } \\
\text { LGM }\end{array}$ & $\begin{array}{l}\text { Warm } \\
\text { LGM }\end{array}$ & Preind. & $\begin{array}{l}\text { Cold } \\
\text { LGM }\end{array}$ & $\begin{array}{l}\text { Warm } \\
\text { LGM }\end{array}$ & Preind. & ModelE & GEOS4 & Literature \\
\hline Loss by $\mathrm{OH}$ in troposphere $\left[\mathrm{Tg} \mathrm{year}^{-1}\right]$ & 82 & 100 & 184 & 64 & 90 & 174 & 66 & 90 & 181 & 460 & 481 & $512^{\mathrm{c}}$ \\
\hline 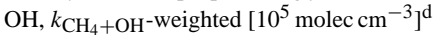 & 12.9 & 13.6 & 12.3 & 10.1 & 12.2 & 11.6 & 11.0 & 13.0 & 12.1 & 12.7 & 13.0 & \\
\hline$\tau_{\mathrm{CH}_{4}, \mathrm{OH}}$ [year] & 12.8 & 10.4 & 10.9 & 16.4 & 11.6 & 11.5 & 15.9 & 11.6 & 11.1 & 10.4 & 9.9 & $10.2_{-0.7}^{+0.9 \mathrm{e}}$ \\
\hline
\end{tabular}

Tropospheric trace gas and aerosol emissions respond to climate, and we simulate reductions in most trace gas emissions in cooler climates. Terrestrial plant VOC emissions are influenced by both land cover and meteorology. A decrease in the present day relative to the preindustrial results from expansions in cropland. In the LGM, the cooler temperatures ultimately drive decreases in plant VOC emissions relative to the preindustrial. Soil microbial emissions of $\mathrm{NO}_{\mathrm{x}}$ also decrease with reduced temperatures and precipitation fluxes at the LGM. Lightning responds to the vertical extent of deep convection, and therefore decreases at the LGM, especially in the cold-LGM scenario. We also test a scenario in which we fix total lightning emissions. Estimates of biomass burning emissions in past atmospheres are highly uncertain; we test the extremes in the range of estimates at the LGM (10 and $200 \%$ of present) and the preindustrial (100 and 320\% of present) using distributions of dry matter burned from the LPJ-LMfire model.

We find net reductions in all oxidants in past atmospheres relative to the present day, except for $\mathrm{H}_{2} \mathrm{O}_{2}$ in the highfire preindustrial simulation, and $\mathrm{OH}$ in the fixed lightning LGM scenarios. OH is relatively well buffered in comparison with the other oxidants. It is relatively insensitive to changes in anthropogenic and fire emissions, but sensitive to lightning. In our simulations, $\mathrm{OH}$ increases at the present day by $+7.0 \pm 4.3 \%$, and shows little change at the LGM $(0.5 \pm 12 \%)$, both relative to the preindustrial. A linear relationship with $J_{\mathrm{O}_{3}} q S_{\mathrm{N}} /\left(S_{\mathrm{C}}^{3 / 2}\right)$ explains $72 \%$ of the total variability seen in the mean $\mathrm{OH}$ burdens of our 11 simulations. $J_{\mathrm{O}_{3}}$ and $q$ largely regulate primary production of $\mathrm{HO}_{\mathrm{x}}$, whereas $S_{\mathrm{N}} /\left(S_{\mathrm{C}}^{3 / 2}\right)$ largely influences $\mathrm{HO}_{\mathrm{x}}$ partitioning between $\mathrm{OH}$ and $\mathrm{RO}_{2}$ (but also primary production).

Most previous studies lacked realistic paleo-stratospheres and simulated larger increases in $\mathrm{OH}$ at the LGM (cf. Table 1). Our work suggests that $\mathrm{OH}$ changes were more tempered, and possibly even reduced at the LGM. Of the various emission sources, lightning is most capable of perturbing $S_{\mathrm{N}} /\left(S_{\mathrm{C}}^{3 / 2}\right)$, as it makes up a relatively large fraction of $S_{\mathrm{N}}\left(37 \pm 16 \%\right.$ of $S_{\mathrm{N}}$ in past atmospheres; $14 \%$ in the present day), and $S_{\mathrm{N}} \ll S_{\mathrm{C}}$. Unlike anthropogenic or fire emissions, $\mathrm{NO}_{\mathrm{x}}$ from lightning also lacks any co-emissions of reactive carbon, and it is relatively uncorrelated with a competing emission source, as soil $\mathrm{NO}_{\mathrm{x}}$ emissions are with those of biogenic VOCs. Therefore, we conclude that the three factors $\mathrm{OH}$ is most sensitive to on glacial-interglacial timescales are overhead ozone, tropospheric water vapor, and lightning emissions. These factors should be given particular attention in future studies.

Ozone in our simulations increases by $24 \pm 11 \%$ at the present and decreases by $12 \pm 10 \%$ at the LGM, relative to the preindustrial. Our changes are consistent with prior studies but more tempered, likely reflecting the high bias in the source of ozone transported from the stratosphere. That source decreases in magnitude in the colder climates following the deceleration of the stratospheric circulation, but nevertheless becomes an increasingly large fraction of the total source. We extend to LGM conditions the finding that global mean ozone from 1850 through 2100 depends strongly on $S_{\mathrm{N}}$ (Stevenson et al., 2006; Young et al., 2013). Ozone production efficiencies per unit $\mathrm{NO}_{\mathrm{x}}$ emitted increase in each successively colder atmosphere.

$\mathrm{H}_{2} \mathrm{O}_{2}$ responds to changes in both climate and emissions, varying more strongly in its production pathways across the different scenarios than in its loss rates via wet deposition. We find that $\mathrm{H}_{2} \mathrm{O}_{2}$ abundance is very sensitive to fire emissions, as these emissions generate $\mathrm{HO}_{\mathrm{x}}$. Ice-core $\mathrm{H}_{2} \mathrm{O}_{2}$ may therefore act as a useful proxy for paleo fire emissions as well as for biogenic emissions, another $\mathrm{HO}_{\mathrm{x}}$ source. Nitrate radical is directly related to the total source of reactive nitrogen, $S_{\mathrm{N}}\left(R^{2}=0.97\right)$.

Our simulations are broadly qualitatively consistent with ice-core records of $\Delta^{17} \mathrm{O}$ in sulfate and nitrate at the LGM, and $\mathrm{CO}, \mathrm{HCHO}$, black carbon, and $\mathrm{H}_{2} \mathrm{O}_{2}$ in the preindustrial. Comparison with black carbon, $\mathrm{CO}$ and $\mathrm{H}_{2} \mathrm{O}_{2}$ preserved in ice cores indicate that fire emissions during the preindustrial and LGM likely fall closer to the lower end of the estimated range. Our simulations indicate that the $\mathrm{HCHO} /$ methane ratio cannot serve as a proxy for global $\mathrm{OH}$ variability, even from future tropical ice cores.

Finally, our work provides greater certainty in the breakdown of the atmospheric methane budget at the LGM. Prior studies disagree as to the relative role of sources vs. sinks in explaining the large glacial-interglacial variability in atmospheric methane concentrations recorded in ice cores. We 
simulate nearly constant or increased methane lifetimes at the LGM relative to the preindustrial, implying that the large glacial-interglacial variability seen in ice-core methane is predominantly driven by changing methane sources. Our results imply that methane emissions decreased by $50 \%$ at the LGM relative to the preindustrial, a greater change than reported in previous bottom-up estimates.

\section{Supplementary material related to this article is available online at http://www.atmos-chem-phys.net/14/ 3589/2014/acp-14-3589-2014-supplement.pdf.}

Acknowledgements. The authors would like to thank C. McLinden (Environment Canada) for providing updated Linoz coefficients for the past atmospheres, N. Mahowald (Cornell U.) for providing LGM mineral dust burdens, A. LeGrande (NASA GISS) for providing LGM boundary conditions for the GCM, and G. Schmidt (NASA GISS) and P. Lin (UW/NOAA GFDL) for useful discussions. This project was funded by NSF grant AGS-1102880 to Harvard University and the University of Washington.

Edited by: P. Jöckel

\section{References}

Adams, J. M., Constable, J. V. H., Guenther, A. B., and Zimmerman, P.: An estimate of natural volatile organic compound emissions from vegetation since the last glacial maximum, Atmos. Environ., 3, 73-91, 2001.

Alexander, B., Savarino, J., Barkov, N., Delmas, R., and Thiemens, M. H.: Climate driven changes in the oxidation pathways of atmospheric sulfur, Geophys. Res. Lett., 29, 1685, doi:10.1029/2002GL014879, 2002.

Alexander, B., Savarino, J., Kreutz, K., and Thiemens, M. H.: Impact of preindustrial biomass-burning emissions on the oxidation pathways of tropospheric sulfur and nitrogen, J. Geophys. Res.Atmos., 109, D08303, doi:10.1029/2003JD004218, 2004.

Allen, D. J., Pickering, K., Duncan, B., and Damon, M.: Impact of lightning NO emissions on North American photochemistry as determined using the Global Modeling Initiative (GMI) model, J. Geophys. Res.-Atmos., 115, D22301, doi:10.1029/2010JD014062, 2010.

Anklin, M. and Bales, R. C.: Recent increase in $\mathrm{H}_{2} \mathrm{O}_{2}$ concentration at Summit, Greenland, J. Geophys. Res.-Atmos., 102, 19099_ 19104, 1997.

Auvray, M. and Bey, I.: Long-range transport to Europe: Seasonal variations and implications for the European ozone budget, J. Geophys. Res.-Atmos., 110, D11303, doi:10.1029/2004JD005503, 2005.

Balkanski, Y., Jacob, D. J., Gardner, G., Graustein, W., and Turekian, K.: Transport and Residence Times of Tropospheric Aerosols Inferred From a Global 3-Dimensional Simulation of Pb-210, J. Geophys. Res.-Atmos., 98, 20573-20586, 1993.
Bartlein, P. J., Harrison, S. P., Brewer, S., Connor, S., Davis, B. A. S., Gajewski, K., Guiot, J., Harrison-Prentice, T. I., Henderson, A., Peyron, O., Prentice, I. C., Scholze, M., Seppa, H., Shuman, B., Sugita, S., Thompson, R. S., Viau, A. E., Williams, J., and $\mathrm{Wu}, \mathrm{H}$.: Pollen-based continental climate reconstructions at 6 and 21 ka: a global synthesis, Clim. Dynam., 37, 775-802, 2011.

Berger, A. L.: Long-term variations of daily insolation and Quaternary climatic changes, J. Atmos. Sci., 35, 2362-2367, 1978.

Berntsen, T. K., Isaksen, I. S. A., Myhre, G., Fuglestvedt, J. S., Stordal, F., Larsen, T. A., Freckleton, R. S., and Shine, K. P.: Effects of anthropogenic emissions on tropospheric ozone and its radiative forcing, J. Geophys. Res., 102, 28101-28126, doi:10.1029/97JD02226, 1997.

Bey, I., Jacob, D. J., Yantosca, R., Logan, J. A., Field, B., Fiore, A., Li, Q., Liu, H., Mickley, L., and Schultz, M.: Global modeling of tropospheric chemistry with assimilated meteorology: Model description and evaluation, J. Geophys. Res.-Atmos., 106, 23073 23095, 2001

Bisiaux, M. M., Edwards, R., McConnell, J. R., Curran, M. A. J., Van Ommen, T. D., Smith, A. M., Neumann, T. A., Pasteris, D. R., Penner, J. E., and Taylor, K.: Changes in black carbon deposition to Antarctica from two high-resolution ice core records, 1850-2000 AD, Atmos. Chem. Phys., 12, 4107-4115, doi:10.5194/acp-12-4107-2012, 2012.

Blunier, T., Chappellaz, J., Schwander, J., Dällenbach, A., Stauffer, B., Stocker, T. F., Raynaud, D., Jouzel, J., Clausen, H. B., Hammer, C. U., and Johnsen, S. J.: Asynchrony of Antarctic and Greenland climate change during the last glacial period, Nature, 394, 739-743, 1998.

Bock, J., Martinerie, P., Witrant, E., and Chappellaz, J.: Atmospheric impacts and ice core imprints of a methane pulse from clathrates, Earth Planet. Sc. Lett., 349-350, 98-108, 2012.

Bousquet, P., Ringeval, B., Pison, I., Dlugokencky, E. J., Brunke, E.G., Carouge, C., Chevallier, F., Fortems-Cheiney, A., Frankenberg, C., Hauglustaine, D. A., Krummel, P. B., Langenfelds, R. L., Ramonet, M., Schmidt, M., Steele, L. P., Szopa, S., Yver, C., Viovy, N., and Ciais, P.: Source attribution of the changes in atmospheric methane for 2006-2008, Atmos. Chem. Phys., 11, 3689-3700, doi:10.5194/acp-11-3689-2011, 2011.

Braconnot, P., Otto-Bliesner, B., Harrison, S., Joussaume, S., Peterchmitt, J.-Y., Abe-Ouchi, A., Crucifix, M., Driesschaert, E., Fichefet, Th., Hewitt, C. D., Kageyama, M., Kitoh, A., Laîné, A., Loutre, M.-F., Marti, O., Merkel, U., Ramstein, G., Valdes, P., Weber, S. L., Yu, Y., and Zhao, Y.: Results of PMIP2 coupled simulations of the Mid-Holocene and Last Glacial Maximum Part 1: experiments and large-scale features, Clim. Past, 3, 261277, doi:10.5194/cp-3-261-2007, 2007a.

Braconnot, P., Otto-Bliesner, B., Harrison, S., Joussaume, S., Peterchmitt, J.-Y., Abe-Ouchi, A., Crucifix, M., Driesschaert, E., Fichefet, Th., Hewitt, C. D., Kageyama, M., Kitoh, A., Loutre, M.-F., Marti, O., Merkel, U., Ramstein, G., Valdes, P., Weber, L., Yu, Y., and Zhao, Y.: Results of PMIP2 coupled simulations of the Mid-Holocene and Last Glacial Maximum - Part 2: feedbacks with emphasis on the location of the ITCZ and mid- and high latitudes heat budget, Clim. Past, 3, 279-296, doi:10.5194/cp-3-279-2007, 2007b.

Braconnot, P., Harrison, S. P., Kageyama, M., Bartlein, P. J., Masson-Delmotte, V., Abe-Ouchi, A., Otto-Bliesner, B., and 
Zhao, Y.: Evaluation of climate models using palaeoclimatic data, Nature Clim. Change, 2, 417-424, 2012.

Brasseur, G., Kiehl, J., Muller, J., Schneider, T., Granier, C., Tie, X., and Hauglustaine, D.: Past and future changes in global tropospheric ozone: Impact on radiative forcing, Geophys. Res. Lett., 25, 3807-3810, 1998.

Brook, E. J., Harder, S., Severinghaus, J., Steig, E. J., and Sucher, C. M.: On the origin and timing of rapid changes in atmospheric methane during the Last Glacial Period, Global Biogeochem. Cy., 14, 559-572, 2000.

Campen, R. K.: Measurements of gasses trapped in a South American ice core: Paleoatmospheric composition and inferred microbial activity, Master's thesis, Pennsylvania State University, 146 pp., 2000.

Campen, R. K., Sowers, T., and Alley, R. B.: Evidence of microbial consortia metabolizing within a low-latitude mountain glacier, Geology, 31, 231-234, 2003.

Castebrunet, H., Genthon, C., and Martinerie, P.: Sulfur cycle at Last Glacial Maximum: Model results versus Antarctic ice core data, Geophys. Res. Lett., 33, L22711, doi:10.1029/2006GL027681, 2006.

Chappellaz, J., Barnola, J. M., Raynaud, D., Korotkevich, Y. S., and Lorius, C.: Ice-core record of atmospheric methane over the past 160,000 years, Nature, 345, 127-131, 1990.

Chappellaz, J., Blunier, T., Raynaud, D., Barnola, J. M., Schwander, J., and Stauffert, B.: Synchronous changes in atmospheric CH4 and Greenland climate between 40 and $8 \mathrm{kyr}$ BP, Nature, 366, 443-445, 1993.

Chappellaz, J., Blunier, T., Kints, S., Dällenbach, A., Barnola, J.M., Schwander, J., Raynaud, D., and Stauffer, B.: Changes in the atmospheric $\mathrm{CH} 4$ gradient between Greenland and Antarctica during the Holocene, J. Geophys. Res., 102, 15987-15997, doi:10.1029/97JD01017, 1997.

Chen, Y. H. and Prinn, R. G.: Estimation of atmospheric methane emissions between 1996 and 2001 using a three-dimensional global chemical transport model, J. Geophys. Res.-Atmos., 111, D10307, doi:10.1029/2005JD006058, 2006.

Chin, M., Rood, R. B., Lin, S. J., Muller, J.-F., and Thompson, A. M.: Atmospheric sulfur cycle simulated in the global model GOCART- Model description and global properties, J. Geophys. Res., 105, 24671-24687, 2000.

Christian, H., Blakeslee, R., Boccippio, D., Boeck, W., Buechler, D., Driscoll, K., Goodman, S., Hall, J., Koshak, W., Mach, D., and Stewart, M.: Global frequency and distribution of lightning as observed from space by the Optical Transient Detector, J. Geophys. Res.-Atmos., 108, 4005, doi:10.1029/2002JD002347, 2003.

Clark, P. U. and Mix, A. C.: Ice sheets and sea level of the Last Glacial Maximum, Quaternary Sci. Rev., 21, 1-7, 2002.

CLIMAP: Surface of Ice-Age Earth, Science, 191, 1131-1137, 1976.

Collins, W. J., Sitch, S., and Boucher, O.: How vegetation impacts affect climate metrics for ozone precursors, J. Geophys. Res., 115, D23308, doi:10.1029/2010JD014187, 2010.

Considine, D. B., Logan, J. A., and Olsen, M. A.: Evaluation of near-tropopause ozone distributions in the Global Modeling Initiative combined stratosphere/troposphere model with ozonesonde data, Atmos. Chem. Phys., 8, 2365-2385, doi:10.5194/acp-8-2365-2008, 2008.
Crutzen, P. J. and Brühl, C.: A model study of atmospheric temperatures and the concentrations of ozone, hydroxyl, and some other photochemically active gases during the glacial, the preindustrial Holocene and the present, Geophys. Res. Lett., 20, 1047-1050, 1993.

Crutzen, P. J. and Zimmermann, P. H.: The changing photochemistry of the troposphere, Tellus B, 43, 136-151, 1991.

Davis, D., Seelig, J., Huey, G., Crawford, J., Chen, G., Wang, Y., Buhr, M., Helmig, D., Neff, W., and Blake, D.: A reassessment of Antarctic plateau reactive nitrogen based on ANTCI 2003 airborne and ground based measurements, Atmos. Environ., 42, 2831-2848, 2008.

Delaygue, G., Masson, V., Jouzel, J., Koster, R. D., and Healy, R. J.: The origin of Antarctic precipitation: a modelling approach, Tellus B, 52, 19-36, 2000.

Diehl, T.: A Global Inventory of Volcanic $\mathrm{SO}_{2}$ Emissions for Hindcast Scenarios, http://www-lscedods.cea.fr/aerocom/ AEROCOM_HC/volc, 2009.

Dlugokencky, E. J., Lang, P. M., Crotwell, A. M., Masarie, K. A., and Crotwell, M. J.: Atmospheric Methane Dry Air Mole Fractions from the NOAA ESRL Carbon Cycle Cooperative Global Air Sampling Network, 1983-2007, Version: 200807-02, Path: ftp://aftp.cmdl.noaa.gov/data/trace_gases/ch4/flask/ surface/, 2008.

Duncan, B. N., Logan, J. A., Bey, I., Megretskaia, I. A., Yantosca, R. M., Novelli, P. C., Jones, N. B., and Rinsland, C. P.: Global budget of CO, 1988-1997: Source estimates and validation with a global model, J. Geophys. Res.-Atmos., 112, D22301, doi:10.1029/2007JD008459, 2007.

Engel, A., Möbius, T., Bönisch, H., Schmidt, U., Heinz, R., Levin, I., Atlas, E., Aoki, S., Nakazawa, T., Sugawara, S., Moore, F., Hurst, D., Elkins, J., Schauffler, S., Andrews, A., and Boering, K.: Age of stratospheric air unchanged within uncertainties over the past 30 years, Nature, 2, 28-31, 2008.

Erbland, J., Vicars, W. C., Savarino, J., Morin, S., Frey, M. M., Frosini, D., Vince, E., and Martins, J. M. F.: Air-snow transfer of nitrate on the East Antarctic Plateau - Part 1: Isotopic evidence for a photolytically driven dynamic equilibrium in summer, Atmos. Chem. Phys., 13, 6403-6419, doi:10.5194/acp-136403-2013, 2013.

Etheridge, D. M., Steele, L. P., Francey, R. J., and Langenfelds, R. L.: Atmospheric methane between 1000 A.D. and present: Evidence of anthropogenic emissions and climatic variability, J. Geophys. Res., 103, 15979-15993, doi:10.1029/98JD00923, 1998.

Fernandes, S. D., Trautmann, N. M., Streets, D. G., Roden, C. A., and Bond, T. C.: Global biofuel use, 1850-2000, Global Biogeochem. Cy., 21, GB2019, doi:10.1029/2006GB002836, 2007.

Fiore, A. M., Dentener, F. J., Wild, O., Cuvelier, C., Schultz, M. G., Hess, P., Textor, C., Schulz, M., Doherty, R. M., Horowitz, L. W., MacKenzie, I. A., Sanderson, M. G., Shindell, D. T., Stevenson, D. S., Szopa, S., Van Dingenen, R., Zeng, G., Atherton, C., Bergmann, D., Bey, I., Carmichael, G., Collins, W. J., Duncan, B. N., Faluvegi, G., Folberth, G., Gauss, M., Gong, S., Hauglustaine, D., Holloway, T., Isaksen, I. S. A., Jacob, D. J., Jonson, J. E., Kaminski, J. W., Keating, T. J., Lupu, A., Marmer, E., Montanaro, V., Park, R. J., Pitari, G., Pringle, K. J., Pyle, J. A., Schroeder, S., Vivanco, M. G., Wind, P., Wojcik, G., Wu, S., and Zuber, A.: Multimodel estimates of intercontinental 
source-receptor relationships for ozone pollution, J. Geophys. Res.-Atmos., 114, D04301, doi:10.1029/2008JD010816, 2009.

Fiore, A. M., Naik, V., Spracklen, D. V., Steiner, A., Unger, N., Prather, M., Bergmann, D., Cameron-Smith, P. J., Cionni, I., Collins, W. J., Dalsoren, S., Eyring, V., Folberth, G. A., Ginoux, P., Horowitz, L. W., Josse, B., Lamarque, J.-F., MacKenzie, I. A., Nagashima, T., O'Connor, F. M., Righi, M., Rumbold, S. T., Shindell, D. T., Skeie, R. B., Sudo, K., Szopa, S., Takemura, T., and Zeng, G.: Global air quality and climate, Chem. Soc. Rev., 41, 6663-6683, doi:10.1039/c2cs35095e, 2012.

Fischer, E. V., Jacob, D. J., Millet, D. B., Yantosca, R. M., and Mao, J.: The role of the ocean in the global atmospheric budget of acetone, Geophys. Res. Lett., 39, L01807, doi:10.1029/2011GL050086, 2012.

Fischer, H., Fundel, F., Ruth, U., Twarloh, B., Wegner, A., Udisti, R., Becagli, S., Castellano, E., Morganti, A., Severi, M., Wolff, E., Littot, G. C., Rothlisberger, R., Mulvaney, R., Hutterli, M. A., Kaufmann, P., Federer, U., Lambert, F., Bigler, M., Hansson, M., Jonsell, U., De Angelis, M., Boutron, C. F., Siggaard-Andersen, M. L., Steffensen, J. P., Barbante, C., Gaspari, V., Gabrielli, P., and Wagenbach, D.: Reconstruction of millennial changes in dust emission, transport and regional sea ice coverage using the deep EPICA ice cores from the Atlantic and Indian Ocean sector of Antarctica, Earth Planet. Sc. Lett., 260, 340-354, 2007.

Fischer, H., Behrens, M., Bock, M., Richter, U., Schmitt, J., Loulergue, L., Chappellaz, J., Spahni, R., Blunier, T., Leuenberger, M., and Stocker, T. F.: Changing boreal methane sources and constant biomass burning during the last termination, Nature, 452, 864-867, 2008.

Fisher, J. A., Jacob, D. J., Wang, Q., Bahreini, R., Carouge, C. C., Cubison, M. J., Dibb, J. E., Diehl, T., Jimenez, J. L., Leibensperger, E. M., Lu, Z., Meinders, M. B. J., Pye, H. O. T., Quinn, P. K., Sharma, S., Streets, D. G., van Donkelaar, A., and Yantosca, R. M.: Sources, distribution, and acidity of sulfateammonium aerosol in the Arctic in winter-spring, Atmos. Environ., 45, 7301-7318, 2011.

Fluckiger, J., Monnin, E., Stauffer, B., Schwander, J., Stocker, T., Chappellaz, J., Raynaud, D., and Barnola, J.: Highresolution Holocene $\mathrm{N}_{2} \mathrm{O}$ ice core record and its relationship with $\mathrm{CH}_{4}$ and $\mathrm{CO}_{2}$, Global Biogeochem. Cy., 16, 1010, doi:10.29/2001GB001417, 2002.

Fountoukis, C. and Nenes, A.: ISORROPIA II: a computationally efficient thermodynamic equilibrium model for $\mathrm{K}^{+}-\mathrm{Ca}_{2}^{+}-\mathrm{Mg}_{2}^{+}$$\mathrm{NH}_{4}^{+}-\mathrm{Na}^{+}-\mathrm{SO}_{4}^{2-}-\mathrm{NO}_{3}-\mathrm{Cl}-\mathrm{H}_{2} \mathrm{O}$ aerosols, Atmos. Chem. Phys., 7, 4639-4659, doi:10.5194/acp-7-4639-2007, 2007.

Frey, M. M., Bales, R. C., and McConnell, J. R.: Climate sensitivity of the century-scale hydrogen peroxide (H2O2) record preserved in 23 ice cores from West Antarctica, J. Geophys. Res., 111, D21301, doi:10.1029/2005JD006816, 2006.

Fuhrer, K., Neftel, A., Anklin, M., and Maggi, V.: Continuous measurements of hydrogen peroxide, formaldehyde, calcium and ammonium concentrations along the new grip ice core from summit, Central Greenland, Atmos. Environ., 27, 1873-1880, 1993.

Garcia, R. R. and Randel, W. J.: Acceleration of the Brewer-Dobson circulation due to increases in greenhouse gases, J. Atmos. Sci., 65, 2731-2739, 2008

Gillett, R. W., Van Ommen, T. D., Jackson, A. V., and Ayers, G. P.: Formaldehyde and peroxide concentrations in Law Dome (Antarctica) firn and ice cores, J. Glaciol., 46, 15-19, 2000.
Grenfell, J. L., Shindell, D. T., Koch, D., and Rind, D.: Chemistryclimate interactions in the Goddard Institute for Space Studies general circulation model: 2. New insights into modeling the preindustrial atmosphere, J. Geophys. Res., 106, 33435-33451, doi:10.1029/2000JD000090, 2001.

Guelle, W., Balkanski, Y., Dibb, J., Schulz, M., and Dulac, F.: Wet deposition in a global size-dependent aerosol transport model 2. Influence of the scavenging scheme on $\mathrm{Pb}-210$ vertical profiles, surface concentrations, and deposition, J. Geophys. Res.-Atmos., 103, 28875-28891, 1998a.

Guelle, W., Balkanski, Y., Schulz, M., Dulac, F., and Monfray, P.: Wet deposition in a global size-dependent aerosol transport model - 1 . Comparison of a 1 year $\mathrm{Pb}-210$ simulation with ground measurements, J. Geophys. Res.-Atmos., 103, 11429$11445,1998 \mathrm{~b}$

Guenther, A., Hewitt, C. N., Erickson, D., Fall, R., Geron, C., Graedel, T., Harley, P., Klinger, L., Lerdau, M., Mckay, W. A., Pierce, T., Scholes, B., Steinbrecher, R., Tallamraju, R., Taylor, J., and Zimmerman, P.: A global model of natural volatile organic compound emissions, J. Geophys. Res., 100, 8873, doi:10.1029/94JD02950, 1995.

Guenther, A., Baugh, W. M., Brasseur, G. P., Greenberg, J., Harley, P., Klinger, L. F., Serça, D., and Vierling, L. A.: Isoprene emission estimates and uncertainties for the Central African EXPRESSO study domain, J. Geophys. Res.-Atmos., 104, 3062530639, 1999.

Guenther, A., Geron, C., Pierce, T., Lamb, B., Harley, P., and Fall, R.: Natural emissions of non-methane volatile organic compounds; carbon monoxide, and oxides of nitrogen from North America, Atmos. Environ., 34, 2205-2230, 2000.

Guenther, A., Karl, T., Harley, P., Wiedinmyer, C., Palmer, P. I., and Geron, C.: Estimates of global terrestrial isoprene emissions using MEGAN (Model of Emissions of Gases and Aerosols from Nature), Atmos. Chem. Phys., 6, 3181-3210, doi:10.5194/acp-63181-2006, 2006.

Guenther, A. B., Jiang, X., Heald, C. L., Sakulyanontvittaya, T., Duhl, T., Emmons, L. K., and Wang, X.: The Model of Emissions of Gases and Aerosols from Nature version 2.1 (MEGAN2.1): an extended and updated framework for modeling biogenic emissions, Geosci. Model Dev., 5, 1471-1492, doi:10.5194/gmd-51471-2012, 2012.

Haan, D. and Raynaud, D.: Ice core record of CO variations during the last two millennia: atmospheric implications and chemical interactions within the Greenland ice, Tellus B, 50, 253-262, 1998.

Haan, D., Martinerie, P., and Raynaud, D.: Ice core data of atmospheric carbon monoxide over Antarctica and Greenland during the last 200 years, Geophys. Res. Lett., 23, 2235-2238, 1996.

Hansen, J., Sato, M., Ruedy, R., Kharecha, P., Lacis, A., Miller, R., Nazarenko, L., Lo, K., Schmidt, G. A., Russell, G., Aleinov, I., Bauer, S., Baum, E., Cairns, B., Canuto, V., Chandler, M., Cheng, Y., Cohen, A., Del Genio, A., Faluvegi, G., Fleming, E., Friend, A., Hall, T., Jackman, C., Jonas, J., Kelley, M., Kiang, N. Y., Koch, D., Labow, G., Lerner, J., Menon, S., Novakov, T., Oinas, V., Perlwitz, J., Perlwitz, J., Rind, D., Romanou, A., Schmunk, R., Shindell, D. T., Stone, P., Sun, S., Streets, D., Tausnev, N., Thresher, D., Unger, N., Yao, M., and Zhang, S.: Climate simulations for 1880-2003 with GISS modelE, Clim. Dynam., 29, 661-696, 2007. 
Harrison, S. P. and Prentice, I. C.: Climate and $\mathrm{CO}_{2}$ controls on global vegetation distribution at the last glacial maximum: analysis based on palaeovegetation data, biome modelling and palaeoclimate simulations, Global Change Biol., 9, 983-1004, 2003.

Hauglustaine, D. and Brasseur, G.: Evolution of tropospheric ozone under anthropogenic activities and associated radiative forcing of climate, J. Geophys. Res.-Atmos., 106, 32337-32360, 2001.

Heald, C. L., Coe, H., Jimenez, J. L., Weber, R. J., Bahreini, R., Middlebrook, A. M., Russell, L. M., Jolleys, M., Fu, T.-M., Allan, J. D., Bower, K. N., Capes, G., Crosier, J., Morgan, W. T., Robinson, N. H., Williams, P. I., Cubison, M. J., DeCarlo, P. F., and Dunlea, E. J.: Exploring the vertical profile of atmospheric organic aerosol: comparing 17 aircraft field campaigns with a global model, Atmos. Chem. Phys., 11, 12673-12696, doi:10.5194/acp-11-12673-2011, 2011.

Hegglin, M. I. and Shepherd, T. G.: Large climate-induced changes in ultraviolet index and stratosphere-to-troposphere ozone flux, Nat. Geosci., 2, 687-691, 2009.

Held, I. M. and Soden, B. J.: Robust responses of the hydrological cycle to global warming, J. Climate, 19, 5686-5699, 2006.

Holmes, C. D., Prather, M. J., Søvde, O. A., and Myhre, G.: Future methane, hydroxyl, and their uncertainties: key climate and emission parameters for future predictions, Atmos. Chem. Phys., 13, 285-302, doi:10.5194/acp-13-285-2013, 2013.

Holton, J., Haynes, P., Mcintyre, M., Douglass, A., Rood, R., and Pfister, L.: Stratosphere-Troposphere Exchange, Rev. Geophys., 33, 403-439, 1995.

Honrath, R. E., Peterson, M. C., Guo, S., Dibb, J. E., Shepson, P. B., and Campbell, B.: Evidence of $\mathrm{NO}_{\mathrm{x}}$ production within or upon ice particles in the Greenland snowpack, Geophys. Res. Lett., 26, 695-698, 1999.

Honrath, R. E., Guo, S., Peterson, M. C., Dziobak, M. P., Dibb, J. E., and Arsenault, M. A.: Photochemical production of gas phase $\mathrm{NO}_{\mathrm{x}}$ from ice crystal $\mathrm{NO}_{3}^{-}$, J. Geophys. Res., 105, 2418324190, doi:10.1029/2000JD900361, 2000.

Horowitz, L. W.: Past, present, and future concentrations of tropospheric ozone and aerosols: Methodology, ozone evaluation, and sensitivity to aerosol wet removal, J. Geophys. Res., 111, D22211, doi:10.1029/2005JD006937, 2006.

Hough, A. M. and Derwent, R. G.: Changes in the global concentration of tropospheric ozone due to human activities, Nature, 344, 645-648, 1990.

Hsu, J. and Prather, M. J.: Stratospheric variability and tropospheric ozone, J. Geophys. Res.-Atmos., 114, D06102, doi:10.1029/2008JD010942, 2009.

Hudman, R. C., Moore, N. E., Mebust, A. K., Martin, R. V., Russell, A. R., Valin, L. C., and Cohen, R. C.: Steps towards a mechanistic model of global soil nitric oxide emissions: implementation and space based-constraints, Atmos. Chem. Phys., 12, 7779-7795, doi:10.5194/acp-12-7779-2012, 2012.

Hutterli, M. A., Bales, R. C., McConnell, J. R., and Stewart, R. W.: HCHO in Antarctic snow: Preservation in ice cores and air-snow exchange, Geophys. Res. Lett., 29, 1235, doi:10.1029/2001GL014256, 2002.

Hutterli, M. A., McConnell, J. R., Bales, R. C., and Stewart, R. W.: Sensitivity of hydrogen peroxide $\left(\mathrm{H}_{2} \mathrm{O}_{2}\right)$ and formaldehyde (HCHO) preservation in snow to changing environmental conditions: Implications for ice core records, J. Geophys. Res., 108, 4023, doi:10.1029/2002JD002528, 2003.
IPCC: Climate Change 2001: The Scientific Basis, Contribution of Working Group I to the Third Assessment Report of the Intergovernmental Panel on Climate Change, Cambridge University Press, Cambridge, UK, 2001.

IPCC: Climate Change 2007: The Physical Science Basis, Contribution of Working Group I to the Fourth Assessment Report of the Intergovernmental Panel on Climate Change, Cambridge University Press, Cambridge, United Kingdom and New York, NY, USA, 2007.

Jaeglé, L., Quinn, P. K., Bates, T. S., Alexander, B., and Lin, J.-T.: Global distribution of sea salt aerosols: new constraints from in situ and remote sensing observations, Atmos. Chem. Phys., 11, 3137-3157, doi:10.5194/acp-11-3137-2011, 2011.

John, J. G., Fiore, A. M., Naik, V., Horowitz, L. W., and Dunne, J. P.: Climate versus emission drivers of methane lifetime against loss by tropospheric OH from 1860-2100, Atmos. Chem. Phys., 12, 12021-12036, doi:10.5194/acp-12-12021-2012, 2012.

Joussaume, S., Taylor, K. E., Braconnot, P., Mitchell, J. F. B., Kutzbach, J. E., Harrison, S. P., Prentice, I. C., Broccoli, A. J., Abe-Ouchi, A., Bartlein, P. J., Bonfils, C., Dong, B., Guiot, J., Herterich, K., Hewitt, C. D., Jolly, D., Kim, J. W., Kislov, A., Kitoh, A., Loutre, M. F., Masson, V., McAvaney, B., McFarlane, N., de Noblet, N., Peltier, W. R., Peterschmitt, J. Y., Pollard, D., Rind, D., Royer, J. F., Schlesinger, M. E., Syktus, J., Thompson, S., Valdes, P., Vettoretti, G., Webb, R. S., and Wyputta, U.: Monsoon changes for 6000 years ago: Results of 18 simulations from the Paleoclimate Modeling Intercomparison Project (PMIP), Geophys. Res. Lett., 26, 859-862, 1999.

Kaplan, J., Bigelow, N., Prentice, I., Harrison, S., Bartlein, P., Christensen, T., Cramer, W., Matveyeva, N., McGuire, A., Murray, D., Razzhivin, V., Smith, B., Walker, D., Anderson, P., Andreev, A., Brubaker, L., Edwards, M., and Lozhkin, A.: Climate change and Arctic ecosystems: 2. Modeling, paleodata-model comparisons, and future projections, J. Geophys. Res.-Atmos., 108, 8171, doi:10.1029/2002JD002559, 2003.

Kaplan, J. O.: Wetlands at the Last Glacial Maximum: Distribution and methane emissions, Geophys. Res. Lett., 29, 1079, doi:10.1029/2001GL013366, 2002.

Kaplan, J. O., Folberth, G., and Hauglustaine, D. A.: Role of methane and biogenic volatile organic compound sources in late glacial and Holocene fluctuations of atmospheric methane concentrations, Global Biogeochem. Cy., 20, GB2016, doi:10.1029/2005GB002590, 2006.

Karol, I., Frolkis, V., and Kiselev, A.: Radiative-Photochemical Modeling of the Annually Averaged Composition and Temperature of the Global Atmosphere During the Last Glacial and Interglacial Periods, J. Geophys. Res.-Atmos., 100, 7291-7301, 1995.

Kettle, A., Andreae, M., Amouroux, D., Andreae, T., Bates, T., Berresheim, H., Bingemer, H., Boniforti, R., Curran, M., DiTullio, G., Helas, G., Jones, G., Keller, M., Kiene, R., Leck, C., Levasseur, M., Malin, G., Maspero, M., Matrai, P., McTaggart, A., Mihalopoulos, N., Nguyen, B., Novo, A., Putaud, J., Rapsomanikis, S., Roberts, G., Schebeske, G., Sharma, S., Simo, R., Staubes, R., Turner, S., and Uher, G.: A global database of sea surface dimethylsulfide (DMS) measurements and a procedure to predict sea surface DMS as a function of latitude, longitude, and month, Global Biogeochem. Cy., 13, 399-444, 1999. 
Khalil, M. A. K. and Rasmussen, R. A.: Atmospheric methane: Trends over the last 10,000 years, Atmos. Environ., 21, 24452452, 1987.

Kim, D., Sobel, A. H., Del Genio, A. D., Chen, Y., Camargo, S. J., Yao, M.-S., Kelley, M., and Nazarenko, L.: The Tropical Subseasonal Variability Simulated in the NASA GISS General Circulation Model, J. Climate, 25, 4641-4659, 2012.

Klein Goldewijk, K., Beusen, A., Van Drecht, G., and De Vos, M.: The HYDE 3.1 spatially explicit database of human-induced global land-use change over the past 12,000 years, Global Ecol. Biogeogr., 20, 73-86, 2011.

Koch, D., Jacob, D. J., and Graustein, W.: Vertical transport of tropospheric aerosols as indicated by $\mathrm{Be}-7$ and $\mathrm{Pb}-210$ in a chemical tracer model, J. Geophys. Res.-Atmos., 101, 18651-18666, 1996.

Koch, D., Menon, S., Del Genio, A., Ruedy, R., Alienov, I., and Schmidt, G. A.: Distinguishing aerosol impacts on climate over the past century, J. Climate, 22, 2659-2677, 2009.

Kuhns, H., Knipping, E. M., and Vukovich, J. M.: Development of a United States-Mexico emissions inventory for the Big Bend Regional Aerosol and Visibility Observational (BRAVO) Study, J. Air Waste Manage., 55, 677-692, doi:10.1080/10473289.2005.10464648, 2005.

Kunasek, S. A., Alexander, B., Steig, E. J., Hastings, M. G., Gleason, D. J., and Jarvis, J. C.: Measurements and modeling of $\Delta^{17} \mathrm{O}$ of nitrate in snowpits from Summit, Greenland, J. Geophys. Res., 113, D24302, doi:10.1029/2008JD010103, 2008.

Kutterolf, S., Jegen, M., Mitrovica, J. X., Kwasnitschka, T., Freundt, A., and Huybers, P. J.: A detection of Milankovitch frequencies in global volcanic activity, Geology, 41, 227-230, 2013.

Lamarque, J. F., Hess, P., Emmons, L., Buja, L., Washington, W., and Granier, C.: Tropospheric ozone evolution between 1890 and 1990, J. Geophys. Res., 110, D08304, doi:10.1029/2004JD005537, 2005.

Lamarque, J.-F., McConnell, J. R., Shindell, D. T., Orlando, J. J., and Tyndall, G. S.: Understanding the drivers for the 20th century change of hydrogen peroxide in Antarctic ice-cores, Geophys. Res. Lett., 38, L04810, doi:10.1029/2010GL045992, 2011.

Lamarque, J.-F., Shindell, D. T., Josse, B., Young, P. J., Cionni, I., Eyring, V., Bergmann, D., Cameron-Smith, P., Collins, W. J., Doherty, R., Dalsoren, S., Faluvegi, G., Folberth, G., Ghan, S. J., Horowitz, L. W., Lee, Y. H., MacKenzie, I. A., Nagashima, T., Naik, V., Plummer, D., Righi, M., Rumbold, S. T., Schulz, M., Skeie, R. B., Stevenson, D. S., Strode, S., Sudo, K., Szopa, S., Voulgarakis, A., and Zeng, G.: The Atmospheric Chemistry and Climate Model Intercomparison Project (ACCMIP): overview and description of models, simulations and climate diagnostics, Geosci. Model Dev., 6, 179-206, doi:10.5194/gmd-6-179-2013, 2013.

Lambert, G., Polian, G., Sanak, J., Ardouin, B., Buisson, A., Jegou, A., and Leroulley, J.: Cycle du radon et de ses descendants: application à l'étude des échanges troposphère-stratosphère, Ann. Geophys., 38, 497-531, 1982,

http://www.ann-geophys.net/38/497/1982/.

Law, K. S. and Pyle, J. A.: Modelling the response of tropospheric trace species to changing source gas concentrations, Atmos. Environ., 25, 1863-1871, 1991.

Law, K. S., Sturges, W. T., Blake, D. R., Burkholder, J. B., Butler, J. H., Cox, R. A., Haynes, P. H., Ko, M. K. W., Kreher, K., Mari,
C., Pfeilsticker, K., Plane, J. M. C., Salawitch, R. J., Schiller, C., Sinnhuber, B. M., von Glasow, R., Warwick, N. J., Wuebbles, D. J., and Yvon-Lewis, S. A.: Chapter 2, Halogenated Very Short-Lived Substances, in: Scientific Assessment of Ozone Depletion: 2006, Global Ozone Research and Monitoring Project - Report No. 50, World Meteorological Organization, Geneva, Switzerland, 2007.

Lawrence, M. G., Jöckel, P., and von Kuhlmann, R.: What does the global mean $\mathrm{OH}$ concentration tell us?, Atmos. Chem. Phys., 1, 37-49, doi:10.5194/acp-1-37-2001, 2001.

LeGrande, A. N., Schmidt, G. A., Shindell, D. T., Field, C. V., Miller, R. L., Koch, D. M., Faluvegi, G., and Hoffmann, G.: Consistent simulations of multiple proxy responses to an abrupt climate change event, P. Natl. Acad. Sci. USA, 103, 837-842, 2006.

Leibensperger, E. M., Mickley, L. J., Jacob, D. J., and Barrett, S. R. H.: Intercontinental influence of $\mathrm{NO}_{\mathrm{x}}$ and $\mathrm{CO}$ emissions on particulate matter air quality, Atmos. Environ., 45, 3318-3324, 2011.

Lelieveld, J. and Dentener, F.: What controls tropospheric ozone?, J. Geophys. Res.-Atmos., 105, 3531-3551, 2000.

Lelieveld, J., Peters, W., Dentener, F., and Krol, M.: Stability of tropospheric hydroxyl chemistry, J. Geophys. Res.-Atmos., 107, 4715, doi:10.1029/2002JD002272, 2002.

Levine, J. G., Wolff, E. W., Jones, A. E., Hutterli, M. A., Wild, O., Carver, G. D., and Pyle, J. A.: In search of an ice core signal to differentiate between source-driven and sink-driven changes in atmospheric methane, J. Geophys. Res., 116, D05305, doi:10.1029/2010JD014878, 2011a.

Levine, J. G., Wolff, E. W., Jones, A. E., and Sime, L. C.: The role of atomic chlorine in glacial-/interglacial changes in the carbon13 content of atmospheric methane, Geophys. Res. Lett., 38, L04801, doi:10.1029/2010GL046122, 2011b.

Levine, J. G., Wolff, E. W., Jones, A. E., Sime, L. C., Valdes, P. J., Archibald, A. T., Carver, G. D., Warwick, N. J., and Pyle, J. A.: Reconciling the changes in atmospheric methane sources and sinks between the Last Glacial Maximum and the pre-industrial era, Geophys. Res. Lett., 38, L23804, doi:10.1029/2011GL049545, 2011c.

Levine, J. G., Wolff, E. W., Hopcroft, P. O., and Valdes, P. J.: Controls on the tropospheric oxidizing capacity during an idealized Dansgaard-Oeschger event, and their implications for the rapid rises in atmospheric methane during the last glacial period, Geophys. Res. Lett., 39, L12805, doi:10.1029/2012GL051866, 2012.

Levy, II, H., Kasibhatla, P. S., Moxim, W. J., Klonecki, A. A., Hirsch, A. I., Oltmans, S. J., and Chameides, W. L.: The global impact of human activity on tropospheric ozone, Geophys. Res. Lett., 24, 791-794, 1997.

Liang, Q., Stolarski, R. S., Kawa, S. R., Nielsen, J. E., Douglass, A. R., Rodriguez, J. M., Blake, D. R., Atlas, E. L., and Ott, L. E.: Finding the missing stratospheric $\mathrm{Br}_{\mathrm{y}}$ : a global modeling study of $\mathrm{CHBr}_{3}$ and $\mathrm{CH}_{2} \mathrm{Br}_{2}$, Atmos. Chem. Phys., 10, 2269-2286, doi:10.5194/acp-10-2269-2010, 2010.

Liao, H., Adams, P., Chung, S., Seinfeld, J., Mickley, L., and Jacob, D. J.: Interactions between tropospheric chemistry and aerosols in a unified general circulation model, J. Geophys. Res.-Atmos., 108, 4001, doi:10.1029/2001JD001260, 2003.

Licciardi, J. M., Clark, P. U., Jenson, J. W., and Macayeal, D. R.: Deglaciation of a Soft-Bedded Laurentide Ice Sheet, Atmos. Environ., 17, 427-448, 1998. 
Liu, H., Jacob, D. J., Bey, I., and Yantosca, R.: Constraints from Pb210 and Be-7 on wet deposition and transport in a global threedimensional chemical tracer model driven by assimilated meteorological fields, J. Geophys. Res.-Atmos., 106, 12109-12128, 2001.

Liu, S. C., Trainer, M., Fehsenfeld, F. C., Parrish, D. D., Williams, E. J., Fahey, D. W., Hubler, G., and Murphy, P. C.: Ozone production in the rural troposphere and the implications for regional and global ozone distributions, J. Geophys. Res., 92, 4191, doi:10.1029/JD092iD04p04191, 1987.

Logan, J. A., Prather, M., Wofsy, S. C., and McElroy, M.: Tropospheric Chemistry - a Global Perspective, J. Geophys. Res.-Oc. Atm., 86, 7210-7254, 1981.

Loulergue, L., Schilt, A., Spahni, R., Masson-Delmotte, V., Blunier, T., Lemieux, B., Barnola, J.-M., Raynaud, D., Stocker, T. F., and Chappellaz, J.: Orbital and millennial-scale features of atmospheric $\mathrm{CH}_{4}$ over the past 800,000 years, Nature, 453, 383-386, 2008.

Lu, Y. and Khalil, M.: Tropospheric OH: model calculations of spatial, temporal, and secular variations, Chemosphere, 23, 397444, 1991

Mahowald, N. M., Yoshioka, M., Collins, W. D., Conley, A. J., Fillmore, D. W., and Coleman, D. B.: Climate response and radiative forcing from mineral aerosols during the last glacial maximum, pre-industrial, current and doubled-carbon dioxide climates, Geophys. Res. Lett., 33, L20705, doi:10.1029/2006GL026126, 2006.

Marenco, A., Gouget, H., Nedelec, P., PAGES, J., and Karcher, F.: Evidence of a Long-Term Increase in Tropospheric Ozone From Pic Du Midi Data Series - Consequences - Positive Radiative Forcing, J. Geophys. Res.-Atmos., 99, 16617-16632, doi:10.1029/94JD00021, 1994.

MARGO Project Members: Constraints on the magnitude and patterns of ocean cooling at the Last Glacial Maximum, Nat. Geosci., 2, 127-132, 2009.

Martinerie, P., Brasseur, G., and Granier, C.: The ChemicalComposition of Ancient Atmospheres - a Model Study Constrained by Ice Core Data, J. Geophys. Res.-Atmos., 100, 1429114304, 1995.

McConnell, J. R., Edwards, R., Kok, G. L., Flanner, M. G., Zender, C. S., Saltzman, E. S., Banta, J. R., Pasteris, D. R., Carter, M. M., and Kahl, J. D. W.: 20th-Century Industrial Black Carbon Emissions Altered Arctic Climate Forcing, Science, 317, 1381-1384, 2007.

McElroy, M. B.: Studies of Polar Ice: Insights for Atmospheric Chemistry, in: Report of the Dahlem Workshop on The Environmental Record in Glaciers and Ice Sheets, edited by: Oeschger, H. and Langway, Jr, C. C., p. 363, John Wiley and Sons, 1989.

McLinden, C., Olsen, S., Hannegan, B., Wild, O., Prather, M., and Sundet, J.: Stratospheric ozone in 3-D models: A simple chemistry and the cross-tropopause flux, J. Geophys. Res.-Atmos., 105, 14653-14665, 2000.

Mickley, L., Murti, P., Jacob, D. J., Logan, J. A., Koch, D., and Rind, D.: Radiative forcing from tropospheric ozone calculated with a unified chemistry-climate model, J. Geophys. Res.-Atmos., 104, 30153-30172, 1999.

Mickley, L., Jacob, D. J., and Rind, D.: Uncertainty in preindustrial abundance of tropospheric ozone: Implications for radiative forcing calculations, J. Geophys. Res.-Atmos., 106, 3389-3399, 2001.

Miyazaki, K., Eskes, H. J., Sudo, K., and Zhang, C.: Global lightning NOx production estimated by an assimilation of multiple satellite datasets, Atmos. Chem. Phys. Discuss., 13, 29203 29261, doi:10.5194/acpd-13-29203-2013, 2013.

Murray, L. T., Jacob, D. J., Logan, J. A., Hudman, R. C., and Koshak, W. J.: Optimized regional and interannual variability of lightning in a global chemical transport model constrained by LIS/OTD satellite data, J. Geophys. Res.-Atmos., 117, D20307, doi:10.1029/2012JD017934, 2012.

Naik, V., Voulgarakis, A., Fiore, A. M., Horowitz, L. W., Lamarque, J.-F., Lin, M., Prather, M. J., Young, P. J., Bergmann, D., Cameron-Smith, P. J., Cionni, I., Collins, W. J., Dalsøren, S. B., Doherty, R., Eyring, V., Faluvegi, G., Folberth, G. A., Josse, B., Lee, Y. H., MacKenzie, I. A., Nagashima, T., van Noije, T. P. C., Plummer, D. A., Righi, M., Rumbold, S. T., Skeie, R., Shindell, D. T., Stevenson, D. S., Strode, S., Sudo, K., Szopa, S., and Zeng, G.: Preindustrial to present-day changes in tropospheric hydroxyl radical and methane lifetime from the Atmospheric Chemistry and Climate Model Intercomparison Project (ACCMIP), Atmos. Chem. Phys., 13, 5277-5298, doi:10.5194/acp-13-5277-2013, 2013.

Neu, J. L., Flury, T., Manney, G. L., Santee, M. L., Livesey, N. J., and Worden, J.: Tropospheric ozone variations governed by changes in the stratospheric circulation, Nat. Geosci., submitted, 2014.

Nightingale, P. D., Liss, P. S., and Schlosser, P.: Measurements of air-sea gas transfer during an open ocean algal bloom, J. Geophys. Res., 27, 2117-2120, 2000a.

Nightingale, P. D., Malin, G., Law, C. S., Watson, A. J., Liss, P. S., Liddicoat, M. I., Boutin, J., and Upstill-Goddard, R. C.: In situ evaluation of air-sea gas exchange parameterizations using novel conservative and volatile tracers, Global Biogeochem. Cy., 14, 373-387, doi:10.1029/1999GB900091, 2000b.

Olivier, J. G.: Global emissions sources and sinks, The Climate System, A. A. Balkema Publishers/Swets \& Zeitlinger Publishers, Lisse, the Netherlands, 2001.

Ott, L. E., Pickering, K. E., Stenchikov, G. L., Allen, D. J., DeCaria, A. J., Ridley, B., Lin, R.-F., Lang, S., and Tao, W.K.: Production of lightning $\mathrm{NO}_{\mathrm{x}}$ and its vertical distribution calculated from three-dimensional cloud-scale chemical transport model simulations, J. Geophys. Res.-Atmos., 115, D04301, doi:10.1029/2009JD011880, 2010.

Park, R., Jacob, D. J., Field, B., Yantosca, R., and Chin, M.: Natural and transboundary pollution influences on sulfatenitrate-ammonium aerosols in the United States: Implications for policy, J. Geophys. Res.-Atmos., 109, D15204, doi:10.1029/2003JD004473, 2004.

Parrella, J. P., Jacob, D. J., Liang, Q., Zhang, Y., Mickley, L. J., Miller, B., Evans, M. J., Yang, X., Pyle, J. A., Theys, N., and Van Roozendael, M.: Tropospheric bromine chemistry: implications for present and pre-industrial ozone and mercury, Atmos. Chem. Phys., 12, 6723-6740, doi:10.5194/acp-12-6723-2012, 2012.

Pavelin, E. G., Johnson, C. E., Rughooputh, S., and Toumi, R.: Evaluation of pre-industrial surface ozone measurements made using Schönbein's method, Atmos. Environ., 33, 919-929, 1999.

Petit, J., Jouzel, J., Raynaud, D., Barkov, N., Barnola, J., Basile, I., Bender, M., Chappellaz, J., Davis, M., Delaygue, G., Delmotte, 
M., Kotlyakov, V., Legrand, M., Lipenkov, V., Lorius, C., Pepin, L., Ritz, C., Saltzman, E., and Stievenard, M.: Climate and atmospheric history of the past 420,000 years from the Vostok ice core, Antarctica, Nature, 399, 429-436, 1999.

Pfeiffer, M. and Kaplan, J. O.: Role of humans and fire for vegetation in Europe during the Last Glacial Maximum, in: Modeling Terrestrial Paleobiogeochemistry - Linking Fire, Biochemistry, Humans, and Climate, edited by: Pfeiffer, M., 165-183, 2013.

Pfeiffer, M., Spessa, A., and Kaplan, J. O.: A model for global biomass burning in preindustrial time: LPJ-LMfire (v1.0), Geosci. Model Dev., 6, 643-685, doi:10.5194/gmd-6-643-2013, 2013.

Pinto, J. P. and Khalil, M.: The stability of tropospheric $\mathrm{OH}$ during ice ages, inter-glacial epochs and modern times, Tellus B, 43, 347-352, 1991.

Pison, I., Bousquet, P., Chevallier, F., Szopa, S., and Hauglustaine, D.: Multi-species inversion of $\mathrm{CH}_{4}, \mathrm{CO}$ and $\mathrm{H}_{2}$ emissions from surface measurements, Atmos. Chem. Phys., 9, 5281-5297, doi:10.5194/acp-9-5281-2009, 2009.

Power, M. J., Marlon, J., Ortiz, N., Bartlein, P. J., Harrison, S. P., Mayle, F. E., Ballouche, A., Bradshaw, R. H. W., Carcaillet, C., Cordova, C., Mooney, S., moreno, P. I., Prentice, I. C., Thonicke, K., Tinner, W., Whitlock, C., Zhang, Y., Zhao, Y., Ali, A. A., Anderson, R. S., Beer, R., Behling, H., Briles, C., Brown, K. J., Brunelle, A., Bush, M., Camill, P., Chu, G. Q., Clark, J., Colombaroli, D., Connor, S., Daniau, A. L., Daniels, M., Dodson, J., Doughty, E., Edwards, M. E., Finsinger, W., Foster, D., Frechette, J., Gaillard, M. J., Gavin, D. G., Gobet, E., Haberle, S., Hallett, D. J., Higuera, P., Hope, G., Horn, S., Inoue, J., Kaltenrieder, P., Kennedy, L., Kong, Z. C., Larsen, C., Long, C. J., Lynch, J., Lynch, E. A., McGlone, M., Meeks, S., Mensing, S., Meyer, G., Minckley, T., Mohr, J., Nelson, D. M., New, J., Newnham, R., Noti, R., Oswald, W., Pierce, J., Richard, P. J. H., Rowe, C., Sanchez Goñi, M. F., Shuman, B. N., Takahara, H., Toney, J., Turney, C., Urrego-Sanchez, D. H., Umbanhowar, C., Vandergoes, M., Vanniere, B., Vescovi, E., Walsh, M., Wang, X., Williams, N., Wilmshurst, J., and Zhang, J. H.: Changes in fire regimes since the Last Glacial Maximum: an assessment based on a global synthesis and analysis of charcoal data, Clim. Dynam., 30, 887-907, 2008.

Power, M. J., Marlon, J. R., Bartlein, P. J., and Harrison, S. P.: Fire history and the Global Charcoal Database: A new tool for hypothesis testing and data exploration, Atmos. Environ., 291, 5259, 2010.

Prather, M.: Numerical Advection by Conservation of 2nd-Order Moments, J. Geophys. Res.-Atmos., 91, 6671-6681, 1986.

Prather, M. J., Holmes, C. D., and Hsu, J.: Reactive greenhouse gas scenarios: Systematic exploration of uncertainties and the role of atmospheric chemistry, Geophys Res Lett, 39, L09803, doi:10.1029/2012GL051440, 2012.

Price, C. and Rind, D.: A Simple Lightning Parameterization for Calculating Global Lightning Distributions, J. Geophys. Res.Atmos., 97, 9919-9933, 1992.

Price, C. and Rind, D.: What Determines the Cloud-to-Ground Lightning Fraction in Thunderstorms, Geophys. Res. Lett., 20, 463-466, 1993

Price, C. and Rind, D.: Modeling Global Lightning Distributions in a General-Circulation Model, Mon. Weather Rev., 122, 19301939, 1994.
Prinn, R., Huang, J., Weiss, R., Cunnold, D., Fraser, P., Simmonds, P., McCulloch, A., Harth, C., Reimann, S., Salameh, P., O'Doherty, S., Wang, R., Porter, L., Miller, B., and Krummel, P.: Evidence for variability of atmospheric hydroxyl radicals over the past quarter century, Geophys. Res. Lett., 32, L07809, doi:10.1029/2004GL022228, 2005.

Pye, H., Liao, H., Wu, S., Mickley, L. J., Jacob, D. J., Henze, D. K., and Seinfeld, J. H.: Effect of changes in climate and emissions on future sulfate-nitrate-ammonium aerosol levels in the United States, J. Geophys. Res., 114, D01205, doi:10.1029/2008JD010701, 2009.

Pyne, S.: Fire: A Brief History, University of Washington Press, 224 pp., 2001

Rayner, N. A., Parker, D. E., Horton, E. B., Folland, C. K., Alexander, L. V., Rowell, D. P., Kent, E. C., and Kaplan, A.: Global analyses of sea surface temperature, sea ice, and night marine air temperature since the late nineteenth century, J. Geophys. Res., 108, 4407, doi:10.1029/2002JD002670, 2003.

Ridley, D. A., Heald, C. L., and Ford, B.: North African dust export and deposition: A satellite and model perspective, J. Geophys. Res., 117, D02202, doi:10.1029/2011JD016794, 2012.

Rind, D.: Atmospheric circulation during the Last Glacial Maximum, in: Encyclopedia of Paleoclimatology and Ancient Environments, 57-61, Springer, 2009.

Rind, D. and Peteet, D.: Terrestrial conditions at the Last Glacial Maximum and CLIMAP sea-surface temperature estimates: Are they consistent?, Atmos. Environ., 24, 1-22, 1985.

Rind, D., Chandler, M., Lonergan, P., and Lerner, J.: Climate change and the middle atmosphere 5. Paleostratosphere in cold and warm climates, J. Geophys. Res., 106, 20195-20212, 2001.

Rind, D., Lerner, J., Jonas, J., and McLinden, C.: Effects of resolution and model physics on tracer transports in the NASA Goddard Institute for Space Studies general circulation models, J. Geophys. Res.-Atmos., 112, D09315, doi:10.1029/2006JD007476, 2007.

Rind, D., Lerner, J., McLinden, C., and Perlwitz, J.: Stratospheric ozone during the Last Glacial Maximum, Geophys. Res. Lett., 36, L09712, doi:10.1029/2009GL037617, 2009.

Roelofs, G.-J., Lelieveld, J., and van Dorland, R.: A threedimensional chemistry/general circulation model simulation of anthropogenically derived ozone in the troposphere and its radiative climate forcing, J. Geophys. Res., 102, 23389-23401, doi:10.1029/97JD02210, 1997.

Rothlisberger, R., Hutterli, M., Wolff, E. W., Mulvaney, R., Fischer, H., Bigler, M., Goto-Azuma, K., Hansson, M. E., Ruth, U., Siggaard-Andersen, M. L., and Steffensen, J. P.: Nitrate in Greenland and Antarctic ice cores: a detailed description of postdepositional processes, Ann. Glaciol., 35, 210-216, 2002.

Röthlisberger, R., Mudelsee, M., Bigler, M., de Angelis, M., Fischer, H., Hansson, M., Lambert, F., Masson-Delmotte, V., Sime, L., Udisti, R., and Wolff, E. W.: The Southern Hemisphere at glacial terminations: insights from the Dome C ice core, Clim. Past, 4, 345-356, doi:10.5194/cp-4-345-2008, 2008.

Röthlisberger, R., Crosta, X., Abram, N. J., Armand, L., and Wolff, E. W.: Potential and limitations of marine and ice core sea ice proxies: an example from the Indian Ocean sector, Quaternary Sci. Rev., 29, 296-302, 2010.

Sander, R., Keene, W. C., Pszenny, A. A. P., Arimoto, R., Ayers, G. P., Baboukas, E., Cainey, J. M., Crutzen, P. J., Duce, R. A., 
Hönninger, G., Huebert, B. J., Maenhaut, W., Mihalopoulos, N., Turekian, V. C., and Van Dingenen, R.: Inorganic bromine in the marine boundary layer: a critical review, Atmos. Chem. Phys., 3, 1301-1336, doi:10.5194/acp-3-1301-2003, 2003.

Sander, S. P., Friedl, R. R., Abbatt, J. P. D., Barker, J. R., Burkholder, J. B., Golden, D. M., Kolb, C. E., Kurylo, M. J., Moortgat, G. K., Wine, P. H., Huie, R. E., and Orkin, V. L.: Chemical Kinetics and Photochemical Data for Use in Atmospheric Studies, Tech. Rep., JPL Publication 10-6, Jet Propulsion Laboratory, Pasadena, available at: http://jpldataeval.jpl.nasa.gov (last access: 7 April 2014), 2011.

Savarino, J., Lee, C., and Thiemens, M. H.: Laboratory oxygen isotopic study of sulfur (IV) oxidation: Origin of the massindependent oxygen isotopic anomaly in atmospheric sulfates and sulfate mineral deposits on Earth, J. Geophys. Res.-Atmos., 105, 29079-29088, 2000.

Schmidt, G. A. and Shindell, D. T.: Atmospheric composition, radiative forcing, and climate change as a consequence of a massive methane release from gas hydrates, Paleoceanography, 18, 1004, doi:10.1029/2002PA000757, 2003.

Schmidt, G. A., Ruedy, R., Hansen, J., Aleinov, I., Bell, N., Bauer, M., Bauer, S., Cairns, B., Canuto, V., Cheng, Y., Del Genio, A., Faluvegi, G., Friend, A., Hall, T., Hu, Y., Kelley, M., Kiang, N., Koch, D., Lacis, A., Lerner, J., Lo, K., Miller, R., Nazarenko, L., Oinas, V., Perlwitz, J., Perlwitz, J., Rind, D., Romanou, A., Russell, G., Sato, M., Shindell, D. T., Stone, P., Sun, S., Tausnev, N., Thresher, D., and Yao, M.: Present-day atmospheric simulations using GISS ModelE: Comparison to in situ, satellite, and reanalysis data, J. Climate, 19, 153-192, 2006.

Schumann, U. and Huntrieser, H.: The global lightning-induced nitrogen oxides source, Atmos. Chem. Phys., 7, 3823-3907, doi:10.5194/acp-7-3823-2007, 2007.

Shepherd, T. G. and McLandress, C.: A Robust Mechanism for Strengthening of the Brewer-Dobson Circulation in Response to Climate Change: Critical-Layer Control of Subtropical Wave Breaking, J. Atmos. Sci., 68, 784-797, 2011.

Shepon, A., Gildor, H., Labrador, L. J., Butler, T., Ganzeveld, L. N., and Lawrence, M. G.: Global reactive nitrogen deposition from lightning $\mathrm{NO}_{\mathrm{x}}$, J. Geophys. Res.-Atmos., 112, D06304, doi:10.1029/2006JD007458, 2007.

Sherwood, S. C., Roca, R., Weckwerth, T. M., and Andronova, N. G.: Tropospheric water vapor, convection, and climate, Rev. Geophys., 48, RG2001, doi:10.1029/2009RG000301, 2010.

Shindell, D. T.: Solar Forcing of Regional Climate Change During the Maunder Minimum, Science, 294, 2149-2152, 2001.

Shindell, D. T., Grenfell, J., Rind, D., Grewe, V., and Price, C.: Chemistry-climate interactions in the Goddard Institute for Space Studies general circulation model 1. Tropospheric chemistry model description and evaluation, J. Geophys. Res.-Atmos., 106, 8047-8075, 2001.

Shindell, D. T., Faluvegi, G., and Bell, N.: Preindustrial-to-presentday radiative forcing by tropospheric ozone from improved simulations with the GISS chemistry-climate GCM, Atmos. Chem. Phys., 3, 1675-1702, doi:10.5194/acp-3-1675-2003, 2003.

Shindell, D. T., Faluvegi, G., Unger, N., Aguilar, E., Schmidt, G. A., Koch, D. M., Bauer, S. E., and Miller, R. L.: Simulations of preindustrial, present-day, and 2100 conditions in the NASA GISS composition and climate model G-PUCCINI, At- mos. Chem. Phys., 6, 4427-4459, doi:10.5194/acp-6-4427-2006, 2006.

Shindell, D. T., Levy, H. I., Schwarzkopf, M. D., Horowitz, L. W., Lamarque, J.-F., and Faluvegi, G.: Multimodel projections of climate change from short-lived emissions due to human activities, J. Geophys. Res.-Atmos., 113, D11109, doi:10.1029/2007JD009152, 2008.

Shindell, D. T., Pechony, O., Voulgarakis, A., Faluvegi, G., Nazarenko, L., Lamarque, J.-F., Bowman, K., Milly, G., Kovari, B., Ruedy, R., and Schmidt, G. A.: Interactive ozone and methane chemistry in GISS-E2 historical and future climate simulations, Atmos. Chem. Phys., 13, 2653-2689, doi:10.5194/acp-13-26532013, 2013.

Sillman, S., Logan, J. A., and Wofsy, S. C.: The Sensitivity of Ozone to Nitrogen-Oxides and Hydrocarbons in Regional Ozone Episodes, J. Geophys. Res.-Atmos., 95, 1837-1851, 1990.

Singarayer, J. S., Valdes, P. J., Friedlingstein, P., Nelson, S., and Beerling, D. J.: Late Holocene methane rise caused by orbitally controlled increase in tropical sources, Nature, 470, 82-85, 2011.

Sitch, S., Cox, P. M., Collins, W. J., and Huntingford, C.: Indirect radiative forcing of climate change through ozone effects on the land-carbon sink, Nature, 448, 791-794, 2007.

Sofen, E. D., Alexander, B., and Kunasek, S. A.: The impact of anthropogenic emissions on atmospheric sulfate production pathways, oxidants, and ice core $\Delta^{17} \mathrm{O}\left(\mathrm{SO}_{4}^{2-}\right)$, Atmos. Chem. Phys., 11, 3565-3578, doi:10.5194/acp-11-3565-2011, 2011.

Sofen, E. D., Alexander, B., Steig, E. J., Thiemens, M. H., Kunasek, S. A., Amos, H. M., Schauer, A. J., Hastings, M. G., Bautista, J., Jackson, T. L., Vogel, L. E., McConnell, J. R., Pasteris, D. R., and Saltzman, E. S.: WAIS Divide ice core suggests sustained changes in the atmospheric formation pathways of sulfate and nitrate since the 19th century in the extratropical Southern Hemisphere, Atmos. Chem. Phys. Discuss., 13, 23089-23138, doi:10.5194/acpd-13-23089-2013, 2013.

Spivakovsky, C., Logan, J. A., Montzka, S., Balkanski, Y., Foreman-Fowler, M., Jones, D., Horowitz, L., Fusco, A., Brenninkmeijer, C., Prather, M., Wofsy, S. C., and McElroy, M.: Three-dimensional climatological distribution of tropospheric OH: Update and evaluation, J. Geophys. Res.-Atmos., 105, 8931-8980, 2000.

Staffelbach, T., Neftel, A., Stauffer, B., and Jacob, D. J.: A Record of the Atmospheric Methane Sink From Formaldehyde in Polar Ice Cores, Nature, 349, 603-605, 1991.

Steinkamp, J. and Lawrence, M. G.: Improvement and evaluation of simulated global biogenic soil NO emissions in an AC-GCM, Atmos. Chem. Phys., 11, 6063-6082, doi:10.5194/acp-11-60632011, 2011.

Stevenson, D., Dentener, F., Schultz, M., Ellingsen, K., van Noije, T., Wild, O., Zeng, G., Amann, M., Atherton, C., Bell, N., Bergmann, D., Bey, I., Butler, T., Cofala, J., Collins, W., Derwent, R., Doherty, R., Drevet, J., Eskes, H., Fiore, A., Gauss, M., Hauglustaine, D., Horowitz, L., Isaksen, I., Krol, M., Lamarque, J., Lawrence, M., Montanaro, V., Muller, J., Pitari, G., Prather, M., Pyle, J., Rast, S., Rodriguez, J., Sanderson, M., Savage, N., Shindell, D. T., Strahan, S., Sudo, K., and Szopa, S.: Multimodel ensemble simulations of present-day and near-future tropospheric ozone, J. Geophys. Res.-Atmos., 111, D08301, doi:10.1029/2005JD006338, 2006. 
Stevenson, D. S., Young, P. J., Naik, V., Lamarque, J.-F., Shindell, D. T., Voulgarakis, A., Skeie, R. B., Dalsoren, S. B., Myhre, G., Berntsen, T. K., Folberth, G. A., Rumbold, S. T., Collins, W. J., MacKenzie, I. A., Doherty, R. M., Zeng, G., van Noije, T. P. C., Strunk, A., Bergmann, D., Cameron-Smith, P., Plummer, D. A., Strode, S. A., Horowitz, L., Lee, Y. H., Szopa, S., Sudo, K., Nagashima, T., Josse, B., Cionni, I., Righi, M., Eyring, V., Conley, A., Bowman, K. W., Wild, O., and Archibald, A.: Tropospheric ozone changes, radiative forcing and attribution to emissions in the Atmospheric Chemistry and Climate Model Intercomparison Project (ACCMIP), Atmos. Chem. Phys., 13, 3063-3085, doi:10.5194/acp-13-3063-2013, 2013.

Streets, D., Bond, T., Carmichael, G., Fernandes, S., Fu, Q., He, D., Klimont, Z., Nelson, S., Tsai, N., Wang, M., Woo, J., and Yarber, K.: An inventory of gaseous and primary aerosol emissions in Asia in the year 2000, J. Geophys. Res.-Atmos., 108, 8809, doi:10.1029/2002JD003093, 2003.

Streets, D. G., Zhang, Q., Wang, L., He, K., Hao, J., Wu, Y., Tang, Y., and Carmichael, G. R.: Revisiting China's CO emissions after the Transport and Chemical Evolution over the Pacific (TRACE-P) mission: Synthesis of inventories, atmospheric modeling, and observations, J. Geophys. Res.-Atmos., 111, D14306, doi:10.1029/2006JD007118, 2006.

Thiemens, M. H.: History and applications of mass-independent isotope effects, Annu. Rev. Earth Pl. Sc., 34, 217-262, 2006.

Thompson, A. M.: The Oxidizing Capacity of the Earths Atmosphere - Probable Past and Future Changes, Science, 256, 11571165, 1992.

Thompson, A. M. and Stewart, R. W.: Effect of chemical kinetics uncertainties on calculated constituents in a tropospheric photochemical model, J. Geophys. Res.-Atmos., 96, 13089-13108, 1991

Thompson, A. M., Chappellaz, J., Fung, I. Y., and Kucsera, T.: The atmospheric $\mathrm{CH} 4$ increase since the Last Glacial Maximum, (2). Interactions with oxidants, Tellus B, 45, 242-257, 1993.

Thompson, L. G.: A 25,000-Year Tropical Climate History from Bolivian Ice Cores, Science, 282, 1858-1864, 1998.

Thonicke, K., Prentice, I. C., and Hewitt, C.: Modeling glacial-interglacial changes in global fire regimes and trace gas emissions, Global Biogeochem, Cy,, 19, GB3008, doi:10.1029/2004GB002278, 2005.

Tie, X., Madronich, S., Walters, S., Edwards, D. P., Ginoux, P., Mahowald, N., Zhang, R. Y., Lou, C., and Brasseur, G.: Assessment of the global impact of aerosols on tropospheric oxidants, J. Geophys. Res., 110, D03204, doi:10.1029/2004JD005359, 2005.

Turekian, K., Nozaki, Y., and Benninger, L.: Geochemistry of Atmospheric Radon and Radon Products, Annu. Rev. Earth Pl. Sc., 5, 227-255, 1977.

Ullman, D. J., LeGrande, A. N., Carlson, A. E., Anslow, F. S., and Licciardi, J. M.: Assessing the impact of Laurentide Ice-Sheet topography on glacial climate, Clim. Past Discuss., 9, 3239-3306, doi:10.5194/cpd-9-3239-2013, 2013.

Valdes, P., Beerling, D., and Johnson, C.: The ice age methane budget, Geophys. Res. Lett., 32, L02704, doi:10.1029/2004GL021004, 2005.

Valentin, M. K.: Numerical modeling of the climatological and anthropogenic influences on the chemical composition of the troposphere since the Last Glacial Maximum, Ph.D. thesis, Johannes Gutenburg Univ., Mainz, Germany, 1990. van der Werf, G. R., Randerson, J. T., Giglio, L., Collatz, G. J., Mu, M., Kasibhatla, P. S., Morton, D. C., DeFries, R. S., Jin, Y., and van Leeuwen, T. T.: Global fire emissions and the contribution of deforestation, savanna, forest, agricultural, and peat fires (19972009), Atmos. Chem. Phys., 10, 11707-11735, doi:10.5194/acp10-11707-2010, 2010.

van der Werf, G. R., Peters, W., van Leeuwen, T. T., and Giglio, L.: What could have caused pre-industrial biomass burning emissions to exceed current rates?, Clim. Past, 9, 289-306, doi:10.5194/cp-9-289-2013, 2013.

van Donkelaar, A., Martin, R. V., Leaitch, W. R., Macdonald, A. M., Walker, T. W., Streets, D. G., Zhang, Q., Dunlea, E. J., Jimenez, J. L., Dibb, J. E., Huey, L. G., Weber, R., and Andreae, M. O.: Analysis of aircraft and satellite measurements from the Intercontinental Chemical Transport Experiment (INTEX-B) to quantify long-range transport of East Asian sulfur to Canada, Atmos. Chem. Phys., 8, 2999-3014, doi:10.5194/acp-8-2999-2008, 2008.

van Leeuwen, T. T. and van der Werf, G. R.: Spatial and temporal variability in the ratio of trace gases emitted from biomass burning, Atmos. Chem. Phys., 11, 3611-3629, doi:10.5194/acp11-3611-2011, 2011.

vanOmmen, T. and Morgan, V.: Peroxide concentrations in the Dome Summit South ice core, Law Dome, Antarctica, J. Geophys. Res.-Atmos., 101, 15147-15152, 1996.

Voulgarakis, A., Naik, V., Lamarque, J.-F., Shindell, D. T., Young, P. J., Prather, M. J., Wild, O., Field, R. D., Bergmann, D., CameronSmith, P., Cionni, I., Collins, W. J., Dalsøren, S. B., Doherty, R. M., Eyring, V., Faluvegi, G., Folberth, G. A., Horowitz, L. W., Josse, B., MacKenzie, I. A., Nagashima, T., Plummer, D. A., Righi, M., Rumbold, S. T., Stevenson, D. S., Strode, S. A., Sudo, K., Szopa, S., and Zeng, G.: Analysis of present day and future $\mathrm{OH}$ and methane lifetime in the ACCMIP simulations, Atmos. Chem. Phys., 13, 2563-2587, doi:10.5194/acp-13-25632013, 2013.

Wang, Q., Jacob, D. J., Fisher, J. A., Mao, J., Leibensperger, E. M., Carouge, C. C., Le Sager, P., Kondo, Y., Jimenez, J. L., Cubison, M. J., and Doherty, S. J.: Sources of carbonaceous aerosols and deposited black carbon in the Arctic in winter-spring: implications for radiative forcing, Atmos. Chem. Phys., 11, 1245312473, doi:10.5194/acp-11-12453-2011, 2011.

Wang, Y. and Jacob, D. J.: Anthropogenic forcing on tropospheric ozone and $\mathrm{OH}$ since preindustrial times, J. Geophys. Res.Atmos., 103, 31123-31135, 1998.

Wang, Y., Jacob, D. J., and Logan, J. A.: Global simulation of tropospheric $\mathrm{O}_{3}-\mathrm{NO}_{\mathrm{X}}$-hydrocarbon chemistry 1 . Model formulation, J. Geophys. Res.-Atmos., 103, 10713-10725, 1998.

Wang, Z., Chappellaz, J., Park, K., and Mak, J. E.: Large variations in Southern Hemisphere biomass burning during the last 650 years, Science, 330, 1663-1666, 2010.

Warwick, N. J., Pyle, J. A., Carver, G. D., Yang, X., Savage, N. H., O'Connor, F. M., and Cox, R. A.: Global modeling of biogenic bromocarbons, J. Geophys. Res, 111, D24305, doi:10.1029/2006JD007264, 2006.

Waugh, D. W. and Hall, T. M.: Age of stratospheric air: Theory, observations, and models, Rev. Geophys., 40, 1010, doi:10.1029/2000RG000101, 2002.

Wayne, R. P., Barnes, I., Biggs, P., Burrows, J. P., Canosa-Mas, C. E., Hjorth, J., Le Bras, G., Moortgat, G. K., Perner, D., 
Poulet, G., Restelli, G., and Sidebottom, H.: The nitrate radical: Physics, chemistry, and the atmosphere, Atmos. Environ., 25, 1203, 1991.

Webb, R., Rind, D., Lehman, S., Healy, R., and Sigman, D.: Influence of ocean heat transport on the climate of the Last Glacial Maximum, Nature, 385, 695-699, 1997.

Weber, S. L., Drury, A. J., Toonen, W. H. J., and van Weele, M.: Wetland methane emissions during the Last Glacial Maximum estimated from PMIP2 simulations: Climate, vegetation, and geographic controls, J. Geophys. Res., 115, D06111, doi:10.1029/2009JD012110, 2010.

Wesely, M.: Parameterization of Surface Resistances to Gaseous Dry Deposition in Regional-Scale Numerical-Models, Atmos. Environ., 23, 1293-1304, 1989.

Wilks, D. S.: Statistical Methods in the Atmospheric Sciences, Vol. 100 of International Geophysics Series, Elsevier Academic Press, Oxford, UK, 3 Edn., 2011.

Williams, E.: Lightning and climate: A review, in: Atmos. Res., 272-287, MIT, Cambridge, MA 02139 USA, 2005.

Williams, E., Mushtak, V., Rosenfeld, D., Goodman, S., and Boccippio, D.: Thermodynamic conditions favorable to superlative thunderstorm updraft, mixed phase microphysics and lightning flash rate, in: Atmos Res, 288-306, MIT, Cambridge, MA 02139 USA, 2005.

Wolff, E. W., Rankin, A. M., and Rothlisberger, R.: An ice core indicator of Antarctic sea ice production?, Geophys. Res. Lett., 30, 2158, doi:10.1029/2003GL018454, 2003.

Wolff, E. W.: Chemical signals of past climate and environment from polar ice cores and firn air, Chem. Soc. Rev., 41, 62476258, 2012.

Wolff, E. W., Fischer, H., Fundel, F., Ruth, U., Twarloh, B., Littot, G. C., Mulvaney, R., Röthlisberger, R., De Angelis, M., Boutron, C. F., Hansson, M., Jonsell, U., Hutterli, M., Lambert, F., Kaufmann, A. J., Stauffer, B., Severi, M., Wagenbach, D., Barbante, C., Gabrielli, P., and Gaspari, V.: Southern Ocean sea-ice extent, productivity and iron flux over the past eight glacial cycles, Nature, 440, 491-496, 2006.

Wolff, E. W., Barbante, C., Becagli, S., Bigler, M., Boutron, C. F., Castellano, E., De Angelis, M., Federer, U., Fischer, H., Fundel, F., Hansson, M., Hutterli, M. A., Jonsell, U., Karlin, T., Kaufmann, P., Lambert, F., Littot, G. C., Mulvaney, R., Rothlisberger, R., Ruth, U., Severi, M., Siggaard-Andersen, M. L., Sime, L. C., Steffensen, J. P., Stocker, T., Traversi, R., Twarloh, B., Udisti, R., Wagenbach, D., and Wegner, A.: Changes in environment over the last 800,000 years from chemical analysis of the EPICA Dome C ice core, Quaternary Sci. Rev., 29, 285-295, 2010.
Wu, S., Mickley, L. J., Jacob, D. J., Logan, J. A., Yantosca, R. M., and Rind, D.: Why are there large differences between models in global budgets of tropospheric ozone?, J. Geophys. Res.-Atmos., 112, D05302, doi:10.1029/2006JD007801, 2007.

Yang, X., Pyle, J. A., and Cox, R. A.: Sea salt aerosol production and bromine release: Role of snow on sea ice, Geophys. Res. Lett., 35, L16815, doi:10.1029/2008GL034536, 2008.

Yevich, R. and Logan, J. A.: An assessment of biofuel use and burning of agricultural waste in the developing world, Global Biogeochem. Cy., 17, 1095, doi:10.1029/2002GB001952, 2003.

Yienger, J. and Levy, H.: Empirical-Model of Global Soil-Biogenic $\mathrm{NO}_{\mathrm{x}}$ Emissions, J. Geophys. Res.-Atmos., 100, 11447-11464, 1995.

Young, P. J., Archibald, A. T., Bowman, K. W., Lamarque, J.-F., Naik, V., Stevenson, D. S., Tilmes, S., Voulgarakis, A., Wild, O., Bergmann, D., Cameron-Smith, P., Cionni, I., Collins, W. J., Dalsøren, S. B., Doherty, R. M., Eyring, V., Faluvegi, G., Horowitz, L. W., Josse, B., Lee, Y. H., MacKenzie, I. A., Nagashima, T., Plummer, D. A., Righi, M., Rumbold, S. T., Skeie, R. B., Shindell, D. T., Strode, S. A., Sudo, K., Szopa, S., and Zeng, G.: Preindustrial to end 21 st century projections of tropospheric ozone from the Atmospheric Chemistry and Climate Model Intercomparison Project (ACCMIP), Atmos. Chem. Phys., 13, 20632090, doi:10.5194/acp-13-2063-2013, 2013.

Ziemke, J. R., Chandra, S., Labow, G. J., Bhartia, P. K., Froidevaux, L., and Witte, J. C.: A global climatology of tropospheric and stratospheric ozone derived from Aura OMI and MLS measurements, Atmos. Chem. Phys., 11, 9237-9251, doi:10.5194/acp11-9237-2011, 2011. 